Portland State University

PDXScholar

\title{
The Holocene History of Bison in the Intermountain West: A Synthesis of Archaeological and Paleontological Records from Eastern Oregon
}

Nicole Anne Stutte

Portland State University

Follow this and additional works at: https://pdxscholar.library.pdx.edu/open_access_etds

Part of the Archaeological Anthropology Commons

Let us know how access to this document benefits you.

\section{Recommended Citation}

Stutte, Nicole Anne, "The Holocene History of Bison in the Intermountain West: A Synthesis of Archaeological and Paleontological Records from Eastern Oregon" (2004). Dissertations and Theses. Paper 2257.

https://doi.org/10.15760/etd.2254

This Thesis is brought to you for free and open access. It has been accepted for inclusion in Dissertations and Theses by an authorized administrator of PDXScholar. Please contact us if we can make this document more accessible: pdxscholar@pdx.edu. 


\section{THESIS APPROVAL}

The abstract and thesis of Nicole Anne Stutte for the Master of Arts in Anthropology were presented February 11, 2004, and accepted by the thesis committee and the department.

COMMITTEE APPROVALS:
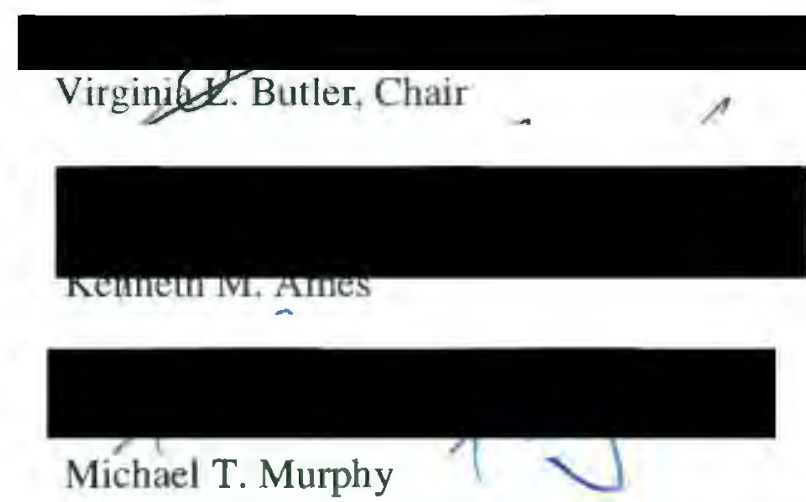

Representative of the Office of Graduate Studies

\section{DEPARTMENT APPROVAL:}



Kenneth M. Ames, Chair

Department of Anthropology 


\begin{abstract}
An abstract of the thesis of Nicole Anne Stutte for the Master of Arts in Anthropology presented February 11, 2004.
\end{abstract}

Title: The Holocene History of Bison in the Intermountain West: A Synthesis of Archaeological and Paleontological Records from Eastern Oregon.

Intermountain West bison abundance and chronology is much debated, but little work addressing these debates has occurred in eastern Oregon. Historic records indicate bison were absent from eastern Oregon at Euro-American contact. However, during explorations in eastern Oregon in 1826 Ogden reported bison skeletons in a dry lake bed, suggesting bison once lived in the area.

This study reviews archaeological and paleontological records, and ethnohistoric accounts of early $19^{\text {th }}$ century explorers, to synthesize the Holocene history of bison eastern Oregon. Bison NISP (number of identified specimens) was documented from site reports when available, and overall abundance was measured by number of sites and number of dated components containing bison. Optimal foraging theory suggests archaeofaunal assemblages can be used to determine abundance of high-ranked prey such as bison in the paleoenvironment. To determine bison 
chronology for undated archaeological and paleontological contexts, 15 bison bone samples were selected for AMS dating.

In total, 136 archaeological site reports were reviewed, 102 include discussions of faunal analysis, and 20 provide evidence of bison. Two paleontological records provided sufficient data to include in this study. Bison NISP values were relatively small and in reports offering quantitative faunal data, bison represented a minimal percentage of the total mammalian assemblage. Of the AMS results, five were problematic and excluded from the study, and ten provided unambiguous ages ranging from $800-160$ BP. Previously published dates in conjunction with new AMS dates support a late Holocene presence of bison in eastern Oregon. Bison are present, yet scarce, in the early Holocene and altogether absent between 7,000-3,000 BP.

Research results for this study are similar to those from other Intermountain West regions. Research suggests large ungulates such as bison were never abundant in the Intermountain West due to environmental constraints. Grassland degradation caused by the introduction of cattle provides proof that the region is inappropriate for large grazing herds. Understanding the prehistory of bison in the region has implications for management of modern herds as well as grassland conservation issues. 
THE HOLOCENE HISTORY OF BISON IN THE INTERMOUNTAIN WEST: A SYNTHESIS OF ARCHAEOLOGICAL AND PALEONTOLOGICAL RECORDS FROM EASTERN OREGON

by

NICOLE ANNE STUTTE

A thesis submitted in partial fulfillment of the requirements for the degree of

MASTER OF ARTS

in

ANTHROPOLOGY

Portland State University

2004 


\section{Acknowledgements}

Several people and organizations deserve acknowledgement for assisting

me in this study. My graduate advisor, Virginia Butler was extremely encouraging throughout the process. She provided me with resources, ideas, technical support, and assisted with grant applications and presentations outside of the thesis writing process. The other committee members, Ken Ames and Michael Murphy also provided support during the writing process.

This project was supported financially by a great number of individuals and institutions. To start with the impetus for the project came from a generous grant from the Bureau of Land Management. I thank Scott Thomas for organizing this grant and for seeing the value in my research. The University of Arizona AMS lab provided funding for radiocarbon dates and the opportunity to visit the lab and learn the AMS dating process. I thank Greg Hodgins, Timothy Jull, and the entire staff at the lab for invaluable knowledge I received. Special thanks to Greg and Rosalind Hodgins for their hospitality during my stay in Tucson. I would also like to thank Barnie Pavao-Zuckerman for the use of the University of Arizona zooarchaeology comparative collection. Financial support also came from the Association of Oregon Archaeologists and the Oregon Archaeological Society. Both organizations deserve acknowledgement for their continued support of student research projects in Oregon. 
Several museums participated in this study as well; these include the Benton County Museum of which Judith Sutliff is the curator, the University of Puget Sound Slater Museum of Natural History curated by Gary Shugart, and the Oregon State Museum of Anthropology, curated by Pam Endzweig. I would like to thank each one of the curators for their support, and for access to the collections. Dennis Jenkins who is also affiliated with the Oregon State Museum of Anthropology provided advice, references, and accesses to Billy the Bison for comparative use. Dennis also provided a bison bone sample from the Paisley Caves archaeological site.

Several individuals deserve acknowledgement for participation and support. These include Bill and Wright Wilbur, Steve Wert, Dirk Van Vuren, Shawn Steinmetz, Dennis Griffen, Brandy Scott, and David Percy.

I would also like to thank the US Fish and Wildlife Service, Cultural Resources Team (Anan Raymond, Jorie Clark, Alex Bourdeau, Virginia Parks, Carla Burnside, and Nick Valentine) for continued support, advice, friendship, and for helping to keep me employed! I would also like to thank my wonderful family for their support and interest in my research. Finally, thank you Henry for putting up with in times of stress and for continued emotional support. 
Table of Contents

Page

Acknowledgements......................................... i

List of Tables.................................................. $v$

List of Figures............................................ vi

Chapter

1 Introduction............................................. 1

2 Background....................................... 6

Review of Historic Documents.................. 6

Review of Archaeological and Paleontological

Documents......................................... 12

Bison Ecology and Grassland Evolution.......... 19

Review of Bison Evolutionary Studies............ 22

Implications of Previous Bison Studies........... 24

3 Methods and Materials.................................. 27

Geographic Study Area........................ 27

Bison Archival Research....................... 30

Establishing Bison Chronology................... 33

Issues of Identification........................ 34

Bison Bone Documentation....................... 35

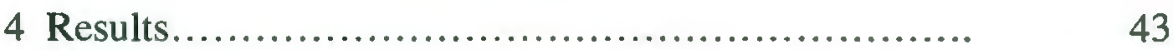

Archival Research Results........................ 43

Columbia Plateau......................... $\quad 52$ 


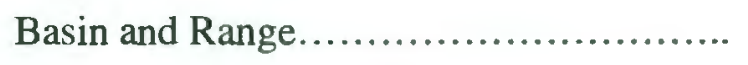

Summary of Archival Research.................. 67

Radiocarbon Dating Results...................... 68

5 Discussion and Conclusion............................. $\quad 76$

Spatial Distribution of Bison in Eastern Oregon...... 76

Synthesis of Bison Chronology in Eastern Oregon... 78

Bison in the Intermountain West................... 84

Implications for Modern Wildlife Management...... 87

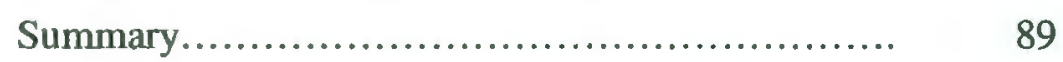

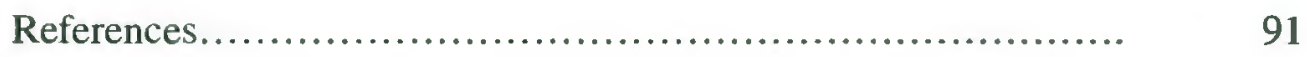

Appendix A

Paleontological and archaeological bison remains in Oregon $\quad 106$

Appendix B

Measurements of postcranial bison elements from archaeological sites in eastern Oregon. Measurements are defined in von den Driesch (1976)...............................

Appendix C

Illustrations of post-cranial mammalian measurements (adapted from von den Driesch 1976)........................

\section{Appendix D}

Skull measurements. Measurements defined in von den Driesch (1976: 29-31).

\section{Appendix E}

Illustrations of skull measurements

(adapted from von den Driesch 1976) 


\section{List of Tables}

Table

2.1 Summary of previous archaeological research in the Intermountain West. Number of archaeological sites or number of dated components containing bison remains per 2,000 year time periods. data points spanning two time periods are counted in both....

2.2 Summary of late Holocene archaeological sites containing bison per 500 year time periods. Data points spanning two time periods are counted in both.

3.1 Weathering stages adapted from Behrensmeyer (1978: 151)..

3.2 Bison bones selected for radiocarbon dating.

4.1 Archaeological bison in eastern Oregon. Highlighted locales are not included in final discussion of bison (see text for discussion)

4.2 Cultural zones and associated radiocarbon ages for Dirty Shame Rockshelter (Aikens et al. 1977, Grayson 1977). Bison quantified using NISP and MNI

4.3 Conventional and calibrated ages of bison bone samples. All ages calibrated using CALIB 4.4 (Stuiver and Reimer 1993), which uses Stuiver et al 1998a, 1998b for $\mathrm{C}^{14}$ calibrations. Conventional ages ending in "pmc" (percent modern carbon) indicate a modern age (sometime after 1950) and may be influenced by secondary atmospheric carbon. Highlighted ages represent questionable dates, see discussion in text.............................

5.1 Dated components per time period for dated bison locales in eastern Oregon. 


\section{List of Figures}

Figure Page

$2.11805-1806$ Corps of Discovery route......................... 8

2.2 Map showing approximate areas of bison research by author

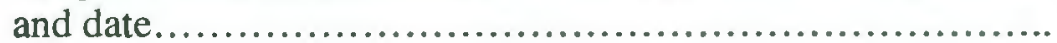

3.1 Map of the physiographic regions of eastern Oregon (adapted from Franklin and Dyrness 1988).............................

3.2 Skull sample, arrow points to left jugular process............

4.1 Counties with bison locales and possible bison locales. Hatching indicates counties with archaeological and/or paleontological bison remains...........................................

4.2 Distribution of archaeological sites reviewed by county and physiographic region, including number of sites with faunal analysis and number with Bison or Bison/Bos remains

4.3 Locations of archaeological and paleontological bison locales in eastern Oregon.............................................

4.4 Calibrated 2-sigma radiocarbon ages of bison bone samples. Calibration curves created using OxCal 3.9 (Bronk 1995, 2001). Atmospheric data for calibrations supplied by CALIB 4.4 (Stuiver and Reimer 1993), which uses Stuiver et al 1998a, 1998b for $\mathrm{C}^{14}$ calibrations

5.1 Number of dated components by eastern Oregon physiographic region

5.2 Number of dated components by time period

5.3 Radiocarbon dating results from archival research and previously undated contexts. Error bars represent 2 sigma calibrated BP midpoints and standard deviation. Some bars represent individual bone dates and others represent dated strata containing bison bone. Standard deviation for Skull Creek Dunes, Lost Dune and Harney Dune were unknown, therefore arbitrarily assigned a standard deviation of 50 for visual purposes. 


\section{Chapter 1 Introduction}

Among all living mammals, bison are perhaps most emblematic of North America and of the fate of wildlife on a continent so long and dramatically transformed, especially under the weight of our own impact (Greene 2002).

The importance of bison to the natural and cultural history of North America cannot be denied. They played an important role in prehistoric human social and economic systems (Bamforth 1988; Steward 1936; Wilson and Davis 1978), caught the attention of American conservationists with the threat of impending extermination (Hornaday 2002; Lott 2002), and heavily influenced the evolution of grassland environments throughout the continent (Barnard and Frankel 1964; Mack and Thompson 1982; Reher 1978). Olsen states, "Due to the buffalo's wide distribution, great numbers and its importance as a major food source of the Indian, its skeletal remains have been found in almost every important archaeological site within the animal's known range" (Olsen 1960: 3).

Several archaeological sites in the Great Plains region and parts of the Snake River Plain contain evidence of communal bison hunting activities, where large numbers of bison were taken at a time (Butler 1971; Lupo and Schmitt 1997; Plew and Sundell 2000; Reher and Frison 1980; Wilson and Davis 1978). On the other hand, fewer records of such obvious bison procurement exist in much of the Intermountain West. Bison abundance and distribution in the Intermountain West has been debated by researchers (Butler 1978; Daubenmire 1985; Lyman 1985b; Schroedl 1973; Van Vuren 1987) but little work has been done to compile 
archaeological and paleontological bison records, which is needed to adequately address the debates.

One area in the Intermountain West lacking a systematic review of bison from archaeological and paleontological sites is eastern Oregon. Paleontological specimens found by early explorers in eastern Oregon provide evidence that bison did at one time exist in the area (Elliott 1909, 1910). Similarly, archaeological sites containing bison remains have dates spanning much of the Holocene. The primary goal of this research is to compile the historic, paleontological, and archaeological records of bison in eastern Oregon. Obtaining radiocarbon ages of bison skeletal remains from previously undated contexts will accompany archival research, resulting in a more comprehensive record of prehistoric bison in the region than currently exists.

Research into the prehistory of bison is important for several reasons. The first of these reasons relates to conservation biology. The only wild herds of bison left in North America are living within the confines of reserves. Within these reserves bison are heavily managed, but are still in danger of extinction because of conflicts with humans, diseases, and lack of forage lands. Cannon proposes that the archaeological record of bison in the Greater Yellowstone Area can provide a "baseline of pre-European conditions against which the modern situation can be assessed and future management decisions can be made" (Cannon 2001:145). According to Cannon, techniques such as stable isotope analysis, DNA analysis, and radiocarbon dating can address long running debates over the diet, species 
determinations, and age of prehistoric bison populations. In turn, these data will be used to manage living herds of bison.

Kay (1994) also addressed Yellowstone paleofaunal data and its relevance to modern management issues. Kay suggests that data from archaeological research and evolutionary studies of grasslands provides evidence that ungulate populations were never as abundant in the Intermountain West asthey were in the Plains. Second, he also argues that ungulate abundance in the Intermountain West has been limited by human hunting activity for thousands of years, and the modern "hands-off" approach to management has resulted in overpopulation and degradation of the environment in reserves such as Yellowstone National Park.

The value of this type of research has been proven in a similar study by Livingston (2000), who examined the relevance of paleofaunas as models for conservation biology. The goal of her work was to provide information on Great Basin mammal paleofaunas that may be applied to planning mammal reserves and assessing management plans for wildlife on public lands. Livingston focused on three species of native artiodactyls from Great Basin sites over the last 25,000 years. She demonstrated that population fluctuations of native artiodactyls over time can be correlated with paleoenvironmental change and human population dynamics. These data are in turn useful for managers of Great Basin preserves who must balance the needs of ranchers and native wildlife populations over valuable grassland habitat. 
A second argument for further research into the prehistory of bison addresses the long running debate over their abundance in the Intermountain West during the Holocene. Early $19^{\text {th }}$ century explorers of eastern Oregon did not observe bison herds during their travels (Elliott 1909, 1910; Moulton 1986-1996). Some scholars argue that bison were present and perhaps abundant in this area before European expansion, but disappeared as a result of human overkill (Christman 1971; Haines 1967; Martin and Szuter 1999; Laliberte and Ripple 2003; Schroedl 1973). Others suggest environmental factors limited bison abundance (Daubenmire 1985; Lyman and Wolverton 2002; Mack and Thompson 1981; Van Vuren 1987). Resolution of these debates has implications for studies of paleoenvironments, anthropological theory, and evolutionary studies of bison and bison habitat.

This research project will address debates over Holocene bison distribution in the Intermountain West, focusing specifically on data from eastern Oregon. Chapter 2 is a review of previous studies in bison abundance and distribution in the Intermountain West. I review historic accounts of bison, archaeological and paleontological reports with references to bison, and literature aimed at understanding bison distribution through ecological and evolutionary research. Chapter 3 outlines the methods and materials used to gather data, including a discussion of radiocarbon dating, as well as techniques used in the literature review of archaeological and ethnohistoric records. Chapter 4 presents project results, including a review of all archaeological sites in eastern Oregon yielding bison 
remains and radiocarbon dating results from selected archaeological and paleontological bison bones. Chapter 5 discusses the results of the study and addresses debates over bison abundance in eastern Oregon as well as the implications of this study to future research on prehistoric mammal populations and modern wildlife management. 


\section{Chapter 2 Background}

Research on the abundance and distribution of bison in the Intermountain West has been approached in different ways. Some research has focused on the historic accounts of early explorers, settlers, and Native Americans. Another type of bison research relies on archaeological and paleontological evidence. Finally, research aimed at the ecology and life history of bison has used evolutionary and ecological perspectives to determine the likelihood of bison occupying certain geographic regions and habitats. The following is a review of previous bison studies in the Intermountain West.

Review of Historic Documents

Historic accounts of early explorers are available through journals kept by travelers. Several of these journals have been reproduced and interpreted in modern times, revealing much information about the environment of North America during the early historic period. There are problems with using such data in attempting to understand past environments (Laliberte and Ripple 2003; Lyman and Wolverton 2002). Explorers were often traveling towards a destination and did not stay in one place for a sufficient period of time to truly understand the environment. They also were seeing mammal and plant species for the first time, and may not have had ecological equivalents where they came from to make accurate identifications. Regardless of these challenges, historical documents are valuable for they provide a starting point for reconstructing early historic period 
environments. This information can subsequently be evaluated by scientific testing through archaeological and paleontological studies.

Any review of historical documents relating to the west must include the diaries of Lewis and Clark. The vast literature dedicated to the interpretation of these diaries has spurred much research aimed at understanding the environment as Lewis and Clark experienced it in the early 1800s (Burroughs 1961, Moulton 19831996). Kingston (1932) reviewed the journals of the Corps of Discovery and other early explorers of the Intermountain West with the goal of learning about the travelers experiences with bison in the early 1800s. As Lewis and Clark entered the Columbia River Basin, their journal entries began to highlight the lack of large game. Kingston, reviewing the diaries of the explorers commented, "Here then was a beautiful region of rolling grasslands, and an abundance of food for herbivorous animals, lakes and running water, a pleasant climate, and yet quite destitute of the buffalo which roamed the vast open regions in the continental interior by the millions" (Kingston 1932: 163).

Lewis and Clark traveled down the Columbia River and did not enter the interior of eastern Oregon (Figure 2.1). Therefore, their journals can not be used to document the distribution of bison in Oregon specifically, yet they do provide a glimpse into the status of large game in the Intermountain West as they traversed the region. 




Figure 2.1 1805-1806 Corps of Discovery route.

When Lewis and Clark traveled through Montana in 1805 and 1806 they encountered abundant herds of game including deer, elk, pronghorn, and bison. Martin and Szuter (1999) suggest that the abundance of game encountered by the Corps of Discovery in this region is due to low human population density.

Territory between tribal boundaries where human population was less dense, were buffer zones for game animals. As the Corps of Discovery traveled across the Continental Divide, they encountered a much different scenario. During the 50 days it took the explorers to get from the Continental Divide to the Cascade Mountains, they only killed 28 deer and bison were not recorded. Also noted in the journals of Lewis and Clark is the fact that during this time, they were seldom out of sight of Native Americans. Martin and Szuter argue that the Columbia River 
Basin was a game sink, too populated by humans to be abundant in large game (Martin and Szuter 1999).

Martin and Szuter (1999) support their hypothesis by tallying the number of animals killed in certain areas from the journal entries of Lewis and Clark. The authors found that the numbers of large game killed were significantly less within the presumed game sink boundaries than in buffer zones between tribal territories. The authors suggest that the relatively small numbers of game in the Columbia River Basin is caused by human predation. They use modern analogy from the successful cattle industry in the region to supporttheir argument. According to Martin and Szuter, the rapid success of the livestock industry in the late $19^{\text {th }}$ century is proof that the land is adequate for ungulate production, and human predation must explain the scarcity of game, not inappropriate habitat and forage.

Lyman and Wolverton (2002) refute Martin and Szuter's argument on several accounts. First, Martin and Szuter's argument that human predation was the cause of game scarcity should be supported by archaeological evidence of bison procurement and utilization. It should be evident through analysis of archaeological faunal remains that bison numbers declined after initial settlement by prehistoric human populations and disappeared some time before Lewis and Clark began their journey. Lyman and Wolverton did not find evidence in the archaeological record to support this supposition. The authors suggest that humans have procured ungulates in the area throughout the last 10,000 years and 
fluctuations in population size and density were likely caused by a combination of climate change, poor habitat, and human predation (Lyman and Wolverton 2002).

Second, Lyman and Wolverton (2002) challenge Martin and Szuter's (1999) analysis of game sink boundaries, tallies of mammals killed, and other Lewis and Clark journal entry details. Lyman and Wolverton re-tallied the number of game kills recorded in the Lewis and Clark journals and found more variation in game abundance within various zones than reported by Martin and Szuter.

Finally, Lyman and Wolverton question the attempt to draw on analogy with the modern livestock industry to claim appropriate habitat for large ungulates existed in the region. The livestock industry in the Columbia Basin only became successful after winter supplementation became necessary due to abundant cattle mortality (Lyman and Wolverton 2002, Young and Sparks 1985).

Following on the work of Lyman and Wolverton (2002) and Martin and Szuter (1999), Laliberte and Ripple (2003) re-evaluated abundance of wildlife encountered by Lewis and Clark spatially by using a geographic information system. They tallied numbers of nine species (including Bison bison) encountered at Lewis and Clark campsites, and measured the distance of these campsites from established human settlements. Their data supported the hypothesis that wildlife abundance was less in areas of denser human populations. Laliberte and Ripple (2003) challenge Lyman and Wolverton's (2002) hypothesis relating changes in animal abundance with climate fluctuations, by claiming that a lack of detailed local climatic data limits confidence in climate related hypotheses. Finally, the 
authors suggest that a decrease in bison abundance between $450 \mathrm{BP}$ and $150 \mathrm{BP}$ can likely be attributed to the introduction of the horse, some time around $230 \mathrm{BP}$, as a potential competitor for resources as well as an agent for increased Native American hunting efficiency.

Arguments concerning the effects of horse utilization by Native Americans on bison populations have used ethno-historic accounts of Native Americans (Haines 1938; Osborne 1953) or comparisons to bison hunting activities on the Plains to suggest similar patterns existed in the Intermountain West. Schroedl (1973) suggests that the later approach is unsuitable for interpretation of bison hunting in the Columbia Plateau given the differences in bison abundance and human subsistence patterns between the two regions. Furthermore, Schroedl (1973) asserts that bison numbers in the Columbia Plateau were in decline over one thousand years before the introduction of the horse.

Peter Skene Ogden is a second explorer who traveled through the Intermountain West in the early $19^{\text {th }}$ century. Ogden traveled throughout the Intermountain West and the Pacific Northwest in search of beaver pelts in 1825 and 1826 (Binns 1967; Elliot 1909, 1910). Ogden commented on the abundance of bison in the Snake River Plain, but did not encounter anylive bison farther to the west, in Oregon (Elliott 1909, 1910). His journal entries do however include the discovery of the skeletal remains of several bison in a dried up lake bed in southeast Oregon, indicating that bison were once in the region. Ogden wrote "Bison have been here, heads are to be seen" (Elliott 1910: 207). 
When Ogden made this statement he was in the vicinity of Malheur and Harney Lakes. Though the exact location of the bone bed Ogden saw is unknown, Vernon Bailey $(1923,1932,1936)$ documented bison skeletons in the dried up lake bed of Malheur Lake almost a century later. Bailey recalls the spectacle and the effort needed to collect skeletal samples from the mud: "In many cases where a skull was lying on top, the complete skeleton could be found under ground, but much patient work was necessary to recover all the bones of these skeletons" (Bailey 1932: 47). Other bison bone localities recorded by Bailey include Willow Creek in the foothills of the Blue Mountains, Cow Creek in Malheur County, and Big Malheur Cave, east of Malheur Lake (Bailey 1923). Paleontological bison locales are important to this study for they provide concrete evidence of the presence bison independent of human subsistence activities.

\section{Review of Archaeological/Paleontological Reports}

Figure 2.2 shows the approximate regions of bison research in the Intermountain West. Douglas Osborn (1953) wrote one of the earliest papers on the archaeological occurrence of bison, pronghorn antelope, and horse in the Columbia Plateau, mainly summarizing the faunal collections from 19 archaeological sites. Osborn assigned mammals to three time periods: prehistoric, protohistoric (late prehistoric), and historic based on their relative depth in archaeological sites and association with historic or prehistoric artifacts. Because Osborn's work was carried out prior to the advent of radiometric dating, it was necessary for him to rely on stratigraphic provenience. 
His findings for bison indicate that in relation to the other mammals in this study, bison were more numerous during prehistoric times, and there is strong evidence that bison existed in the region up until historic times. Osborn admits that his data are insufficient for determining relative abundance. However, the presence of female and fetal bison suggest that breeding herds lived in the region, refuting earlier notions that bison were only casual visitors to the Intermountain West (Dalquest 1948).

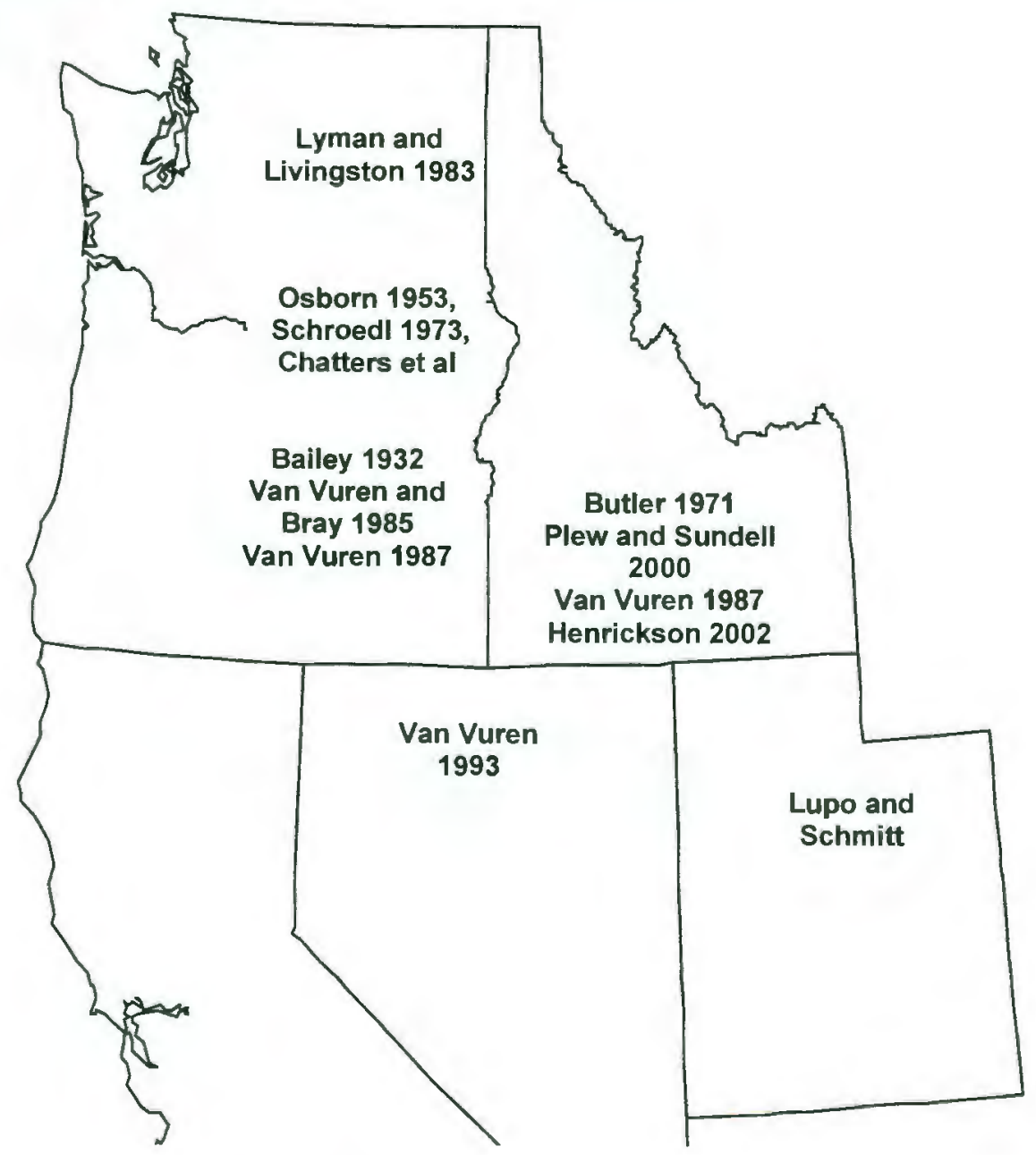

Figure 2.2 Map showing approximate areas of bison research by author and date. 
Gerald Schroedl (1973) compiled faunal records from 32 archaeological sites in the Columbia Plateau including eastern Washington, parts of northeastern Oregon, and Idaho. Schroedl focused on late Holocene aged sites (post 5,000 years $\mathrm{BP}$ ) as he was most interested in the abundance and distribution of modern bison (Bison bison). He mentions early Holocene aged sites such as Lind Coulee, which contains bison bearing deposits, aged approximately $10,000 \mathrm{BP}$, as well as Weis and Marmes Rockshelters, which contain Altithermal aged bison deposits, but does not provide detail about the bison at these sites, nor does he include them hi s summary of bison distribution in the Columbia Plateau.

Schroedl's findings suggest that 19 sites in the Columbia Plateau provide sufficient data to assign bison locales to three time periods. During Schroedl's earliest time period (2500-1500 BP) bison were relatively abundant in the Plateau. This time period is represented by nine archaeological sites, whose ages were obtained by radiocarbon dating and typological artifacts. Bison became scarce by the next time period (1500-500 B.P) as evidenced by seven sites from this time range with bison remains. The final time period (500-150 BP) is based on artifact associations only, no radiocarbon dates are available from the six sites representing this time period.

Schroedl (1973) concludes that the entry of modern bison into the Plateau region around $2500 \mathrm{BP}$ would represent a new human subsistence resource, and this should be evident in the archaeological record in the form of new technology. Schroedl found no sign of changed technology contemporary to the suggested 
timing of bison entry. Schroedl concludes that bison hunting strategy was integrated with existing subsistence strategies, and bison never represented a necessary resource for prehistoric inhabitants of the Columbia Plateau. As bison became locally extinct, perhaps as a result of increased human hunting efficiency, hunters traveled across the Continental Divide to procure bison (Schroedl 1973).

Over the last 15 years, a number of studies from eastern Washington have documented additional archaeological sites containing bison remains. Chatters et al. (1995) report a 2,100 year old bison kill site just west of the Columbia River. The Tsulim site contained the remains of at least eight bison (number of identified specimens $[\mathrm{NISP}]=89$ ) as well as other mammal remains. The authors submitted a sample of bison tooth enamel for radiocarbon dating, which yielded an age of 1508-2752 BP (Chatters et al. 1995).

Morgan (1993) lists 16 bison sites with dated components in the Columbia Plateau; all except one (Wildcat Canyon 35GM9, located south of the Columbia River in Oregon) are in eastern Washington. The 16 sites listed by Morgan (1993) all have bison components dating between 2,500-1,700 B.P; however, only three of these sites contained bison of three or more NISP. Though individual sample sizes are small, the overall number of sites from the $2,500-1,700 \mathrm{BP}$ time period suggests that bison may have been relatively abundant in eastern Washington in the late Holocene.

In Lyman's report on Avey's Orchard archaeological site (1985), he discusses bison in eastern Washington throughout the Holocene. He states that 
bison remains have been recovered from 47 Holocene archaeological sites. Lyman provides a table of the number of dated faunal components and the number of bison bones for each 500 year time period throughout the entire Holocene. The table clearly shows that the greatest number of bison bones was dated between 2,000-500 BP. Statistical testing of the results indicates there is a dependent relationship between the number of dated components and the number of bison bones recovered. The time period in question also has the greatest number of dated faunal components; therefore, any discussion of fluctuations in bison abundance over time from archaeological data in eastern Washington must address sampling and quantification methodology.

Robert Butler compiled data from archaeological and paleontological sites in the Snake River Plain containing bison remains (Butler 1971). Butler makes two claims based on skeletal remains from four archaeological sites in the Snake River Plain: First, he claims bison have been present in the Snake River Plain from the early post-glacial $(12,000$ years ago) through the late prehistoric period, and were most abundant during the late Holocene (3,400-150 BP). Next, he claims the modern form of bison (Bison bison) evolved locally and was not a recent intruder into the region as previously thought (Haines 1967).

Butler's findings include the skeletal remains of both extinct forms of bison (Bison antiquus and occidentalis) as well as modern bison (Bison bison). Butler's claims of prehistoric bison abundance are based upon limited data. He admits that the bison remains he studied were "few in number and lacking in such diagnostic 
elements as the skull and horn cores" (Butler 1971: 8). This limits confidence in species identifications, which some of Butler's arguments rely upon.

In a later paper, Butler (1978) examined the pattern of bison abundance and distribution throughout the entire Intermountain West. By reviewing the work of Schroedl (1973), Butler compared bison records from the Snake River Plain to those from the Columbia Plateau and suggested the two regions differ greatly in bison abundance and chronology. In contrast to Schroedl's hypothesis that bison were numerous by $2,500 \mathrm{BP}$ and in decline by $1500 \mathrm{BP}$, Butler found that records from the Snake River Plain indicate bison were abundant much earlier (3,400-2,900 $\mathrm{BP}$ ) and began declining after 2,900 BP. A resurgence of bison abundance occurred in the Snake River Plain during the late prehistoric period (700-150 BP). Following up on Butler's (1978) work, Plew and Sundell (2000) recently summarized more bison records from the Snake River Plain. Their paper was aimed at extending the knowledge of bison in the region to the western Snake River Plain, an area without much previous work. The authors reviewed 32 archaeological site reports from the Snake River Plain. Their data shows that in varying degrees bison were utilized throughout the Snake River Plain over the past 12,000 years. Most interesting from this study is the evidence of increased bison numbers in the late archaic period (2,000-150 BP). Previous studies aggregated bison chronological records differently (Butler 1978, Schroedl 1973), making it hard to compare with Plew and Sundell's work. It is, however, notable that this time period overlaps with the time period Butler (1978) suggested bison were in decline (2,900-700 BP). 
A major difference between the two studies is in the number of sites used to draw conclusions about changes in bison abundance. Butler (1978) uses data from four locales, whereas Plew and Sundell (2000) use data from 32.

Lupo and Schmitt (1997) compiled archaeofaunal bison records from eight late Holocene sites in the Great Salt Lake area. The authors found much disparity in the number of individuals, age composition, and skeletal part representation over time, which may reflect fluctuations in bison availability, changes in human subsistence activities, or a combination of the two. Overall, their data show a gradual decline in bison abundance throughout the Fremont period (1,600-650 BP), and a significant drop in abundance after $650 \mathrm{BP}$. The authors attribute the decline in abundance to changes in precipitation patterns and continued hunting by prehistoric humans. A shift in precipitation patterns occurring around $650 \mathrm{BP}$ may have resulted in decreased bison forage productivity. Although the authors suggest an environmental cause of bison extinction may be difficult to prove, they support Van Vuren's hypothesis that the modern mosaic habitat of the Intermountain West could not support large breeding herds of bison (Van Vuren 1987).

Lupo and Schmitt did not discuss sites older than $1600 \mathrm{BP}$; however, they did discuss data from other Fremont aged archaeological sites in the northeastern Great Basin. Their data showed that bison were more abundant and represented a higher percentage of the faunal assemblages in Fremont era assemblages than in late prehistoric/protohistoric assemblages. Consistent with other Intermountain studies (Butler 1971; Schroedl 1972), Lupo and Schmitt (1997) suggest that 
prehistoric humans in the Great Salt Lake region most likely obtained, but did not depend upon such a scarce, unpredictable resource.

Henrikson suggested evidence of bison storage in the Snake River Plain proved the importance of bison as a subsistence resource (Henrikson 2002). Bison storage may have been necessary given the unpredictability of the resource in the region. Seven archaeological cave sites in the eastern Snake River Plain provide evidence of bison storage over the last 8,000 years. Though, Henrikson does not evaluate changes in bison abundance over time, an evaluation of her results provides some indication of bison chronology. Two archaeological sites (Tomcat Cave and Bison Heights) with relatively large numbers of bison bones yielded late Holocene ages (1,000-3,000 B.P) (Henrikson 2002).

\section{Bison Ecology and Grassland Evolution}

Several researchers have argued that the differences between bison abundance during prehistoric times east and west of the Rocky Mountains is a result of physiographic differences (Daubenmire 1985, Kingston 1932, Mack and Thompson 1982). Grasslands both east and west of the Rocky Mountains have provided habitat for bison and other large grazing mammals for several thousand years; however, studies of grassland evolution suggest that large grazing mammals were never as abundant on the tall-grass steppes west of the Rockies as they were on the short grass plains east of the Rockies (Mack and Thompson 1982, Grayson 1977). 
Mack and Thompson (1982) identify two major differences between the grasslands east and west of the Rocky Mountains that affect large mammal grazing patterns in the past and the present. One difference lies in the amount and timing of precipitation. West of the Rocky Mountains, grasses evolved with frequent droughts and cold winter precipitation, whereas east of the Rocky Mountains, the bulk of the precipitation occurs during the early summer months. According to Mack and Thompson (1982) the types of grasses that evolved on the short grass plains provided enough forage to sustain large herds of grazing mammals, while the tall-grass species in the western steppe region supported relatively fewer grazers.

The second major difference is the effects of grazing on the different grassland regions (Mack and Thompson 1982). On the short grass plains, the effects of cattle grazing on the plant community are analogous to that of bison grazing in the past. Short-grass communities in the Plains region disturbed by cattle grazing return to their native form with little invasive plant influence. On the other hand, Mack and Thompson (1982) found that in the Intermountain West, the introduction of cattle had a profoundly different effect. Disturbed areas were quickly taken over by Eurasian weeds. Today in the Intermountain West, most of the native grasses have been replaced by non-natives. This reaction to the introduction of large herds of cattle suggests that plant communities in the Intermountain West did not co-evolve with large numbers of grazing mammals as did theshort grass plains (Mack and Thompson 1982). 
Researchers have attempted to use other physiographic differences in grasslands east and west of the Rocky Mountains to explain the lack, or scarcity of grazing mammals such as bison in the Intermountain West. Kingston (1932) argued that barriers such as mountain ranges and deep river valleys kept herds of bison from populating the Intermountain West. According to this hypothesis, those bison that did make it past the geographic barriers were soon killed by Native Americans. This idea can be challenged several ways; first it is wrong to assume bison were not capable of crossing large rivers and deep valleys. Bison athleticism has been demonstrated in modern studies, proving that bison are capable of much greater migrations and survival feats than their domesticated counterparts (Lott 2002). Likewise, the existence of immature and female bison remains in paleontological and archaeological sites in the Intermountain West suggests that breeding populations existed in the region, not just random strays (Butler 1971). Daubenmire (1985) argued that snow depth played a pivotal role in limiting bison in the Intermountain West. He cited several accounts of mass bison deaths caused by severe winter storms in the vicinity of Great Salt Lake. Daubenmire argues that heavy, wet snowfalls common west of the Rockies, and the presence of sagebrush plants which prevent the melting and drifting of snow, limited bison abundance. However, the evidence used to make this assertion is based upon observations of domestic bison (Van Vuren 1987). Any argument for factors limiting the survivability of a wild animal should not hinge upon observations of a domestic breed. Animals with the ability to move freely about the land will react 
much differently in the face of adverse weather, limited resources, or predatory pressure than will domestic animals.

Van Vuren (1987) compiled bison bone accounts from 44 localities (archaeological and paleontological) in eastern Washington, Oregon, and southwestern Idaho. Van Vuren discussed previous research on bison in the Intermountain West (Christman 1971; Daubenmire 1985; Johnson 1951; Kingston 1932; Mack and Thompson 1982; Roe 1970), and provided a new explanation for relatively low bison numbers in the region. Van Vuren suggested that low bison numbers and their disappearance by 1800 can most likely be attributed to inappropriate forage, as suggested by Mack and Thompson (1982), as well as discontinuous "mosaic" habitats. Discontinuous habitat caused isolation of bison populations, which limited breeding capabilities, and recovery from small extinction events (Van Vuren 1987).

\section{Review of Bison Evolutionary Studies}

Understanding the evolutionary pathway of bison in North America is important for resolving questions of their distribution and abundance. Inconsistent methods of determining species of fossil bison have led to varying explanatory hypotheses of bison evolution. Early studies relied fully on horn core characteristics to determine species (Butler 1971). It has since been established that the use of secondary sexual characteristics such as horn cores alone cannot be used to determine species. More recent research has included other craniometric data as well as radiocarbon dating to adjust bison phylogenies (Butler 1971, 
McDonald 1981). Regardless, there is still debate over the temporal sequence of evolutionary relationships between ancient and modern species of bison in North America. Further research including more bison skeletal samples, DNA studies, and radiometric dating are needed to provide a better understanding of bison evolutionary trends.

In studying Holocene era bison, we must take into account that during this time period extinct forms of bison (B. bison antiquus and B. bison occidentalis) and a modern form of bison (B. bison bison) both inhabited North American grasslands. By most recent accounts modern bison replaced the extinct species by $5,000-4,000$ B.P (McDonald 1981). This information is based upon radiocarbon dates from sites east of the Rocky Mountains (McDonald 1981) and archaeological research at sites in the eastern Snake River Plain (Butler 1971). Archaeological sites in the eastern Snake River Plain contain the remains of both extinct and modern bison, suggesting that there was no break in bison habitation for over 12,000 years; however, these data are based on limited sample sizes and questionable species identifications. There remains very little evidence in the Intermountain West that extinct and modern bison species inhabited similar ranges during the same time period.

Bison bison athabascae (Woods bison) is the species often assigned to bison inhabiting boreal forest regions (McDonald 1981). Some have suggested that Woods bison were common in the Intermountain West throughout the Holocene (McDonald 1981). In modern times, this subspecies resides in a Canadian 
preserve. Modern genetics research has proven that there is little genetic difference between Plains bison and Woods bison. The two populations have also successfully interbred (Lott 2002).

The intent of this paper is not to make any conclusions about the species of bison present at locales in the Intermountain West. For this study, modern bison (bison aged less than 5,000 years BP) are referred to as Bison bison. Questions of species determinations to the sub-specific level require larger samples and more thorough examinations of morphology. Evolutionary studies are important to this study, for a understanding of where and when modern bison first appeared in North America may help us delimit population parameters of species both geographically and temporally.

\section{Implications of Previous Bison Studies}

There is much debate over the abundance and chronology of bison in the Intermountain West. One thing is certain, bison were either scarce or absent throughout the Intermountain West during the Euro-American contact period. Explorers to the region commented on a lack of bison in the Columbia Plateau region of Oregon and Washington, and the Basin and Range region of Oregon, both seemingly appropriate for bison habitat (Elliott 1909, 1910; Laliberte and Ripple 2003; Lyman and Wolverton 2002; Martin and Szuter 1999). Paleontological specimens of bison encountered by explorers gave proof that bison were in the region at one time, yet no temporal data was available for understanding the chronology of these specimens. Previous archaeological research on bison suggests 
that more components containing bison remains have been dated to the late

Holocene $2,500-150$ B.P than any other time period (Lupo and Schmitt 1997;

Lyman 1985; Plew and Sundell 2000; Schroedl 1973) (Table 2.1 and 2.2). Early

Holocene records exist, but are rare and most likely represent the remains of an

extinct species of bison (Butler 1971; Schroedl 1973).

Table 2.1 Summary of previous archaeological research in the Intermountain West. Number of archaeological sites or number of dated components containing bison remains per 2,000 year time periods. Data points spanning two time periods are counted in both.

\begin{tabular}{|c|c|c|c|c|c|c|}
\hline \multicolumn{7}{|c|}{ Time Period (BP) } \\
\hline Region (reference) & $\begin{array}{l}\text { quantification method } \\
\text { and comments }\end{array}$ & $\begin{array}{l}2,500 \\
150\end{array}$ & $\begin{array}{l}4,500- \\
2,500\end{array}$ & $\begin{array}{l}6,500 \\
4,500\end{array}$ & $\begin{array}{l}8,500 \\
6,500\end{array}$ & $\begin{array}{l}10,500 \\
8,500\end{array}$ \\
\hline $\begin{array}{l}\text { Snake River Plain } \\
\text { (Plew and Sundell } \\
\text { 2000) }\end{array}$ & number of sites & 16 & 7 & 9 & 8 & 4 \\
\hline $\begin{array}{l}\text { Southern Columbia } \\
\text { Plateau } \\
\text { (Chatters et al. 1995) }\end{array}$ & $\begin{array}{l}\text { number of sites (only } \\
\text { included sites with } \\
>10 \% \text { Bison by NISP) }\end{array}$ & 8 & 3 & & 1 & 1 \\
\hline $\begin{array}{l}\text { Eastern Washington } \\
\text { (Lyman 1985) }\end{array}$ & $\begin{array}{l}\text { total number of bison } \\
\text { bones }\end{array}$ & 837 & 167 & 87 & 97 & $246^{*}$ \\
\hline
\end{tabular}

*164 of the total number of bison bones from the 9,000-7,000 time period recorded by Lyman (1985) are from one locale (Lind Coulee).

Table 2.2 Summary of late Holocene archaeological sites containing bison per 500 year time periods. Data points spanning two time periods are counted in both.

Time Period (BP)

\begin{tabular}{|c|c|c|c|c|c|c|}
\hline Region (reference) & $\begin{array}{l}\text { quantification method } \\
\text { and comments }\end{array}$ & $\begin{array}{l}500- \\
150\end{array}$ & $\begin{array}{l}1,000- \\
500\end{array}$ & $\begin{array}{l}1,500 \\
1,000\end{array}$ & $\begin{array}{l}2,000 \\
1,500\end{array}$ & $\begin{array}{l}2,500 \\
2,000\end{array}$ \\
\hline $\begin{array}{l}\text { Northeastern Great } \\
\text { Basin (Lupo and } \\
\text { Schmitt } 1997\end{array}$ & $\begin{array}{l}\text { number of sites (age } \\
\text { midpoints) }\end{array}$ & 11 & 16 & 17 & 8 & \\
\hline $\begin{array}{l}\text { Salt Lake (Lupo and } \\
\text { Schmitt 1997) }\end{array}$ & number of sites & 3 & 9 & 6 & 1 & \\
\hline $\begin{array}{l}\text { Columbia Plateau } \\
\text { (Schroedl 1973) }\end{array}$ & number of sites & 6 & 7 & 7 & 10 & 10 \\
\hline
\end{tabular}


The goal of my research is to evaluate archaeological and paleontological bison records from eastern Oregon to answer three main questions: First, what is the chronology of bison in eastern Oregon, and does this pattern support or refute bison research from other regions of the Intermountain West? Second, can the records from Oregon be used to address debates over bison abundance in the Intermountain West? If so, do they support or refute previous hypotheses of fluctuating bison abundance over time in the Intermountain West? Finally, can the records from Oregon provide data relevant to modern management issues? 


\section{Chapter 3 Methods and Materials}

This study provides a summary of the Holocene history of bison in eastern Oregon, a geographic region known from historical documents and archaeological and paleontological faunal assemblages to have supported bison populations at times throughout the Holocene. Establishing the presence or absence of a taxon from a specified geographic location in the past requires an in-depth review of all archaeological literature, and ethnohistoric documents. Likewise, radiocarbon dating of previously undated contexts provides a more complete temporal chronology of bison. The following methods were used to aid in the process of reconstructing the temporal and spatial sequence of bison in eastern Oregon.

\section{Geographic Study Area}

Eastern Oregon can be defined as all land east of the crest of the Cascade Mountains and within the modern day borders of Oregon. I limited my study to these confines for several reasons. First, preliminary research suggested that bison were indeed present in the area during the Holocene. Second, archaeological site records are organized by state and county, therefore searching for archival data by state is the most efficient method. Finally, there are long running debates over the presence and abundance of bison in eastern Oregon, and resolving these debates depends upon a thorough understanding of the natural and cultural history of bison in the region. Eastern Oregon is an extremely diverse region. Franklin and Dyrness (1988) have delimited five physiographic regions in eastern Oregon based on landform, drainage, vegetation type, soil type, and climate. These are the 
Columbia Plateau, the Blue Mountains, The High Lava Plains, Owyhee Uplands, and Basin and Range (Figure 3.1). For this study the Basin and Range and Owyhee Uplands regions are aggregated based upon similarity in archaeological sites between these two regions.

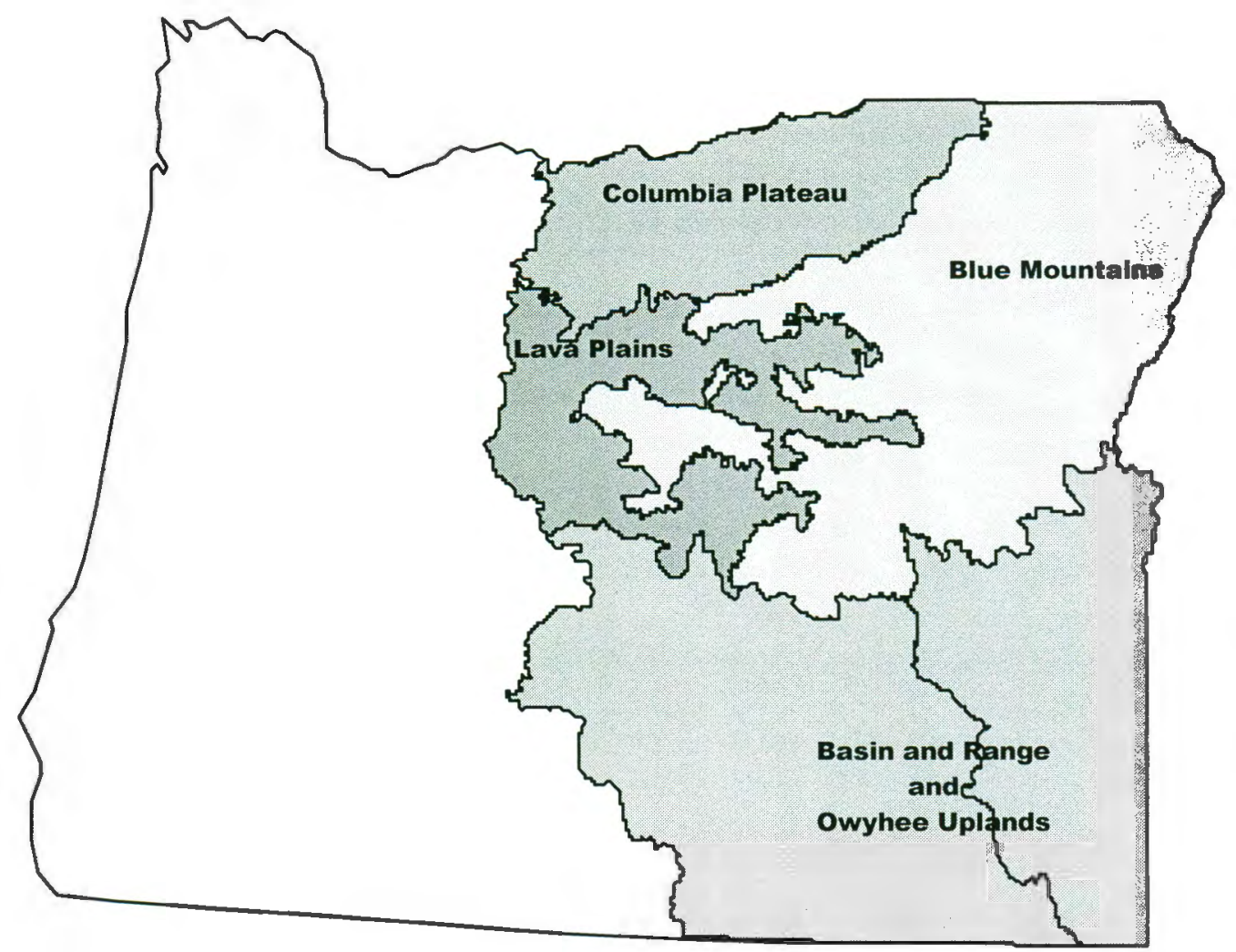

Figure 3.1 Map of the physiographic regions of eastern Oregon (adapted from Franklin and Dyrness 1988).

Physiographic differences may have contributed to the distribution pattern of prehistoric bison. Bison habitat has been described by McDonald (1981) as falling into three categories: forests and woodlands, savannas and steppes, and open 
grasslands. Savannas and steppes and open grasslands are the most common bison habitat (Lott 2002). The eastern Oregon landscape has changed much throughout the Holocene. Climate change, volcanic events, and both naturally and culturally caused fire greatly altered the land; therefore, the modern landscape may not be appropriate for predicting prehistoric bison distribution to a fine scale.

Though the goal of this paper is not to evaluate ecosystem evolution in eastern Oregon, a general understanding may aid us in predicting appropriate bison habitat. The Columbia Plateau and the Basin and Range physiographic regions, both contain a variety of soils that formed under grassland or shrub-grassland vegetation (Franklin and Dyrness 1988). Therefore, these physiographic regions may have been appropriate for prehistoric bison habitat. Soils in the Lava Plains also formed under shrub-grassland vegetation; however, volcanic events during the Holocene severely altered the landscape and affected the distribution of plants and animals (Franklin and Dyrness 1988). Finally, the higher elevation regions such as the Blue Mountains evolved mostly under forest vegetation (Franklin and Dyrness 1988). Those physiographic regions evolving with grassland or shrub-grassland vegetation are most likely to have been appropriate bison habitat, yet more detailed paleoenvironmental data are needed to evaluate prehistoric ecosystem conditions during the Holocene and bison habitat limitations set by these conditions. 


\section{Bison ArchivalResearch}

Archival research for this study included the review of published and unpublished archaeological and paleontological reports as well as ethnohistoric accounts of early explorers. The process of culling reports included a visit to the Oregon State Historic Preservation Office, conversations with state and federal archaeologists, consultation with professors of archaeology and geology, and personal research time in a university library. The goal of archival research was to compile records of bison from archaeological and paleontological reports to better understand the temporal and spatial distribution of bison in eastern Oregon.

Archaeofaunal records can be used to determine the presence or absence of species in the paleoenvironment, yet challenges exits because of the complex relationship between humans and prey animals. Archaeofaunas are a product of human subsistence activities; therefore, "One can never be sure, consequently, how much of the fossil collection reflects hunter selectivity and how much reflects environmental conditions..." (Lyman 1982: 365). For questions of presence or absence of a species, the recovery of an individual element of the target species may not necessarily be proof of local prehistoric presence (Lyman 1995). Humans may transport faunal remains from kill sites to camp sites or trade high value items such as bone artifacts over long distances (Lyman 1995).

This issue is pertinent to this study because ethnohistoric accounts tell of Native Americans traveling across the Continental Divide to procure bison after they became extinct in the Intermountain West (Schroedl 1973). Researchers 
suggest bison meat procured during these trips was consumed near the kill site, and not brought back over the mountains. Bison products, including horns and hides, however, were considered valuable trade items in the Plateau and may have been brought back from Plains hunting trips (Anastasio 1972). Nevertheless, the presence of low utility elements such as skulls and lower limb bones, or those elements least likely to be transported long distances will be most valuable to establishing a local presence of bison.

There are several reasons species may be absent from an archaeofaunal assemblage (Lyman 1995). The species may have been absent, or rare within the study region; the remains of the species may not have been preserved in the assemblage; the sampling methodology used during excavation or research may have resulted in a biased collection; and finally, the species in question may not have been regularly procured by prehistoric hunters because of its limited value relative to other species.

Optimal foraging theory predicts that certain species are more likely to be taken by prehistoric hunters than others, and when available these species will dominate archaeofaunal assemblages (Bayham 1979). Given their large body size and gregarious nature, bison are ranked highly on prey ranking scales (Henrikson 2002). It can therefore be assumed that where or when bison were available, they were procured by prehistoric hunters. This knowledge allows us to conclude that the absence of bison from archaeofaunal assemblages likely reflects their absence or rarity in the local paleoenvironment. Though optimal foraging theory is valuable 
for predicting the anthropogenic influences on archaeofaunas it is not independent of environmental change or changes in human subsistence patterns.

Archaeofaunas represent a sample of the target population; therefore absolute abundance cannot be estimated using archaeofaunal assemblages. Relative abundance is a much more reasonable measurement, and provides a way to interpret changes over time and across space in paleoenvironments. NISP (number of identified specimens) and MNI (minimum number of individuals) are the two most common methods of quantifying relative abundance in archaeofaunal assemblages (Grayson 1984). Measures of relative abundance are not independent of sample size, yet it is unknown how large a sample must be to truly reflect the paleoecology (Grayson 1984). Considering the previous discussion of optimal foraging theory, a small sample of bison may reflect their prehistoric abundance more accurately than that of a lower ranked prey species. Other explanations must include sampling error as a result of excavation and collection methods.

Determining bison abundance from previous research is difficult given varying methods of quantification. Quantification methodology used in previous bison studies has included measurements of bison abundance by number of sites or number of dated components containing bison remains (Butler 1971; Lupo and Schmitt 1997; Plew and Sundell 2000; Schroedl 1973), measurements of bison NISP (Lyman 1985), and measurements of relative frequency of bison in comparison to other species within an assemblage (Lupo and Schmitt 1997; Lyman 1985). Eastern Oregon bison archaeofaunal records have not been quantified using 
a systematic methodology; therefore, my choices for measuring bison abundance were limited. To summarize the results of previous archaeofaunal research in eastern Oregon, I collected bison NISP values as well as the number of dated archaeological components containing bison. When further quantification data were available from reports, I included this in a discussion of the locale in the results section.

My study includes bison from paleontological sites, yet no chronology has been established for these locales. Paleontological sites provide data on bison locales independent of human activity; for this reason paleofaunal samples provide a more confident representation of the paleoenvironment than do archaeofaunal samples. Paleontological sites are however, subject to the same post-depositional taphonomic processes and sampling error derived from collection methodology. For consistency, I collected similar data from both archaeological and paleontological sites (when available). This included the number of individual specimens (NISP); element, side, and portion of each bone; condition of bones (evidence of weathering, root etching, leaching, etc.); where bones were found (i.e. provenience); and evidence of human or carnivore induced taphonomy, age of the bones, and method of dating.

\section{Establishing Bison Chronology}

Previous reports used differing methods to establish the age of bison from archaeological sites. These methods include radiocarbon dating, association with typological artifacts, and stratigraphic provenience, or any combination of the 
three. With such varation in methodology, intra -site temporal comparisons were difficult. From previous reports, I chose to use temporal data from reports only if the methodology was explicitly stated and either radiocarbon dating or typological artifact association were included in this methodology. Several eastern Oregon cave sites with components containing bison bones were assigned to early Holocene ages based on the idea that these skeletal remains were those of extinct species (Cressman et al.1940; Cressman 1942). Subsequent work at these sites, with more precise methods of dating, including radiocarbon dating, indicated that these were late Holocene deposits (Bedwell 1973). It has also been suggested that several caves in eastern Oregon, have disturbed strata, which limits reliability of dates based on stratigraphic provenience unless associated with typological artifacts or radiocarbon dates.

\section{Issues of Identification}

In reviewing faunal records, identifications were often listed as "possible bison" or "Bison/Bos", indicating that the specimen may be that of bison or of other large artiodactyls, including Cervus (elk), or other bovids such as Bos (cow). These sites were included in my count of possible bison locales. Large bovid remains from unequivocally prehistoric deposits can be accepted as bison with little question. However, if confidence is lacking in the stratigraphic control of the deposits, or if they are found in association with historic artifacts, it is best to treat the bovid remains as Bos/Bison (Driver 1992), unless morphological criteria have been explicitly used. 


\section{Bison Bone Documentation}

From the archival research it became apparent that chronological information was lacking for several bison bone locales in eastern Oregon. Radiocarbon dating of these locales would greatly enhance their value. Through several grants, funds became available for radiocarbon dating, and bison bones were carefully selected for the process. The following is an explanation of the procedures used in documenting and selecting samples for radiocarbon dating.

Specimens selected for documentation and radiocarbon dating included archaeological and paleontological bison remains from previously undated contexts or dated contexts where dates were taken prior to the advent of AMS dating. These specimens were from museum, federal and state, and private collections. Efforts were made at tracking down as many bison bones as possible, however due to financial constraints, only those housed in local curation facilities were sampled.

Comparative collections and identification manuals were used to check all documented bison bones. Comparative collections used in this study are located at Portland State University, Oregon State Museum of Anthropology, and the University of Arizona. The importance of using comparative collections and identification manuals is discussed by Olsen (1960). He warns that without a comparative collection or a key, misidentifications may be made when attempting to discern cows (Bos) from bison (Bison). Although the cow and bison have some similar skeletal characteristics, Olsen states, "There are sufficient features in a 
partial skeleton to differentiate between the two animals in question" (Olsen 1960:

5). Several identification keys exist to aid the researcher in making these identifications (Olsen 1960, Balkwill and Cumbaa 1992), however, it is highly recommended that a comparative collection is used as well.

Morphometric data were collected on all documented skeletal elements (Appendix B, D). Though these measurements are not critical to my research goals, they may be useful in future studies focusing on species, age, and sex determinations. Each specimen was measured using standard measurements from von den Driesch (1976), and age classifications were determined using Frison and Reher (1970). Measuring instruments used include slide-gage calipers, curved calipers, and a measuring board. Measurements were taken to the tenth of a centimeter. Each measurement was taken three times to reduce error and the mean was used as the final result.

In choosing bone samples for radiocarbon dating, several physical characteristics of the bone are important. The physical condition of the bone may affect the ability of the researcher to assign proper identifications as well as influence the outcome of radiocarbon dating. Condition of bone includes level of fragmentation, presence of contaminants, and weathering stage.

For each documented bone sample, the weathering stage was noted using Behrensmeyer's (1978) weathering stages (Table 3.1). Beherensmeyer defines weathering as "...the process by which the original microscopic organic and inorganic components of bone are separated from each other and destroyed by 
physical and chemical agents operating on the bone in situ, either on the surface or within the soil zone" (1978: 153). By this definition it is obvious that a minimal amount of weathering is desired on bones that will be sampled for radiocarbon dating, since a sizeable amount of organic material is needed. In choosing bone samples for radiocarbon dating I avoided bones assigned to weathering stage 5 according to Behrensmeyer's criteria.

As well as taphonomic agents acting on the bones in situ, concern exists over other post-excavation processes. Several of the bones I sampled were housed in museums where preservatives were applied to preserve the bone from decay. This included the application of lacquers, glues, marking the bones with ink, and the wiring of elements together to preserve their structure. These alterations were noted and contaminated areas were avoided when sampling for radiocarbon dating. Table 3.1 Weathering stages adapted from Behrensmeyer (1978: 151).

Stage
\begin{tabular}{|c|l|}
\hline 0 & Criteria \\
\hline 1 & $\begin{array}{l}\text { Cracking parallel to the fiber structure, mosaic cracking may be present, skin } \\
\text { and tissue may be present }\end{array}$ \\
\hline 2 & $\begin{array}{l}\text { Outermost layers of bone showing flaking, long thin flakes still partially } \\
\text { attached to the bone are present, deeper flaking follows, crack edges are } \\
\text { angular in cross-section, remnants of ligaments and cartilage may be present }\end{array}$ \\
\hline 3 & $\begin{array}{l}\text { Fibrous texture of bone exists in patches, all external concentrically layered } \\
\text { bone removed, weathering does not penetrate deeper than } 1.0-1.5 \text { mm, crack } \\
\text { edges are rounded in cross-section, tissues rarely present }\end{array}$ \\
\hline 4 & $\begin{array}{l}\text { Coarse fibrous bone surface, large and small splinters present, weathering } \\
\text { penetrates into inner cavities }\end{array}$ \\
\hline 5 & $\begin{array}{l}\text { Bone is falling apart in situ, original bone shape may be difficult to determine, } \\
\text { cancellous bone is exposed }\end{array}$ \\
\hline
\end{tabular}


The dating method used in this study is Accelerator Mass Spectrometry (AMS). Samples were run at Beta Analytic Labs and the University of Arizona AMS laboratory. To obtain accurate radiocarbon ages, at least 2-5 grams of dense (non-cortical) bone is needed (Beta Analytic, personal communication 2002, University of Arizona, personal communication 2002). The AMS dating method begins with pretreatment procedures to eliminate secondary carbon components and the extraction of inorganic bone compounds.

The next step in pretreatment is to recover $\mathrm{CO}_{2}$ from the collagen samples, eliminating water and nitrogen compounds. This is done cryogenically in a combustion line. $\mathrm{CO}_{2}$ is then graphitized, and run through the accelerator for $\mathrm{C}^{14}$ dating. $\mathrm{C}^{13}$ and $\mathrm{C}^{12}$ isotopes are counted and the ratio of these two isotopes $\left({ }^{13}\right)$ is used to correct $\mathrm{C}^{14}$ ages. Radiocarbon BP ages were calibrated using CALIB 4.4 (Stuiver and Reimer 1993), which use atmospheric data for calibration from Stuiver et al. (1998a, 1998b).

Both laboratories "normalize" or correct for isotopic fractionation. This is done by applying the ${ }^{13}$ value to conventional ages and correcting for either laboratory or natural isotopic fractionation. Anomalous ${ }^{13}$ values can represent error in the dating process such as an inadequate amount of collagen to begin with or a contamination error not eliminated during the pretreatment process. This value can also represent information regarding the environment from which the sample comes. Researchers have identified a means by which the isotopic fractionation of natural substances ingested by an animal, such as grasses, can alter the ${ }^{13}$ value 
of that animal's bones (Chisholm et al. 1995; Tieszen 1994). It is for this reason that anomalous ${ }^{13}$ values should alert researchers to the possibility of inaccurate $\mathrm{C}^{14}$ ages, yet also may provide useful data in itself and therefore should not be completely disregarded. Anomalous ${ }^{13}$ values were omitted from my final discussion of bison chronology. These will be discussed in detail in the results section.

In choosing samples to submit for radiocarbon testing, I used the following criteria: The bone should be free of visual contaminants, the bone should be relatively dense (non-cortical), the sampled portion should not be useful for species, age, or sex determinations, the bone shows a weathering stage of four or less (Table 3.1). Finally, the sample could be removed without destroying the entire bone fragment. On skull samples, I chose to take the jugular process, which could be taken without harming other elements or visually impairing a skull that may be used in museum displays (Figure 3.2). A total of 15 bison bones were sampled for radiocarbon dating (Table 3.2). 


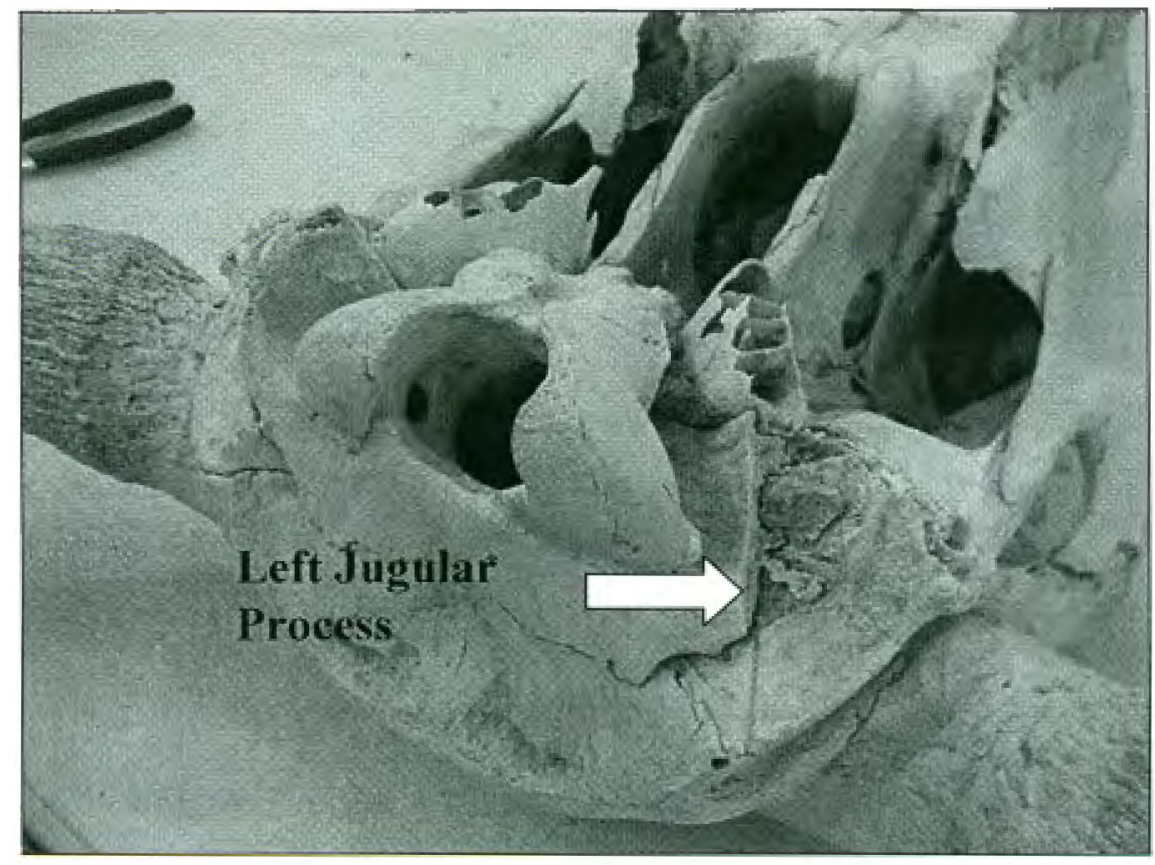

Figure 3.2 Skull sample, arrow points to left jugular process. 
Table 3.2 Bison bones selected for radiocarbon dating.

\begin{tabular}{|c|c|c|c|c|c|c|}
\hline locale & curation facility & element & $\begin{array}{c}\text { weathering } \\
\text { stage }\end{array}$ & date coll. & collector & site type \\
\hline \multirow{3}{*}{$\begin{array}{l}\text { Juniper Lake } \\
\text { 35HA22 }\end{array}$} & \multirow{3}{*}{$\begin{array}{l}\text { Bureau of Land } \\
\text { Management, Burns } \\
\text { Oregon }\end{array}$} & $\begin{array}{l}\text { right } \\
\text { scapula }\end{array}$ & 4 & 2002 & Thompson & Archaeo \\
\hline & & $\begin{array}{l}\text { distal end right } \\
\text { femur }\end{array}$ & 4 & 2002 & Thomas & Archaeo \\
\hline & & $\begin{array}{l}\text { distal end left femur } \\
\text { (unfused) }\end{array}$ & 4 & 2002 & Thomas & Archaeo \\
\hline \multirow{3}{*}{ Malheur Lake } & $\begin{array}{l}\text { Benton County } \\
\text { Museum }\end{array}$ & skull & 3 & 1932 & West & Paleo \\
\hline & \multirow{2}{*}{$\begin{array}{l}\text { University of Puget } \\
\text { Sound Slater } \\
\text { Museum of Natural } \\
\text { History }\end{array}$} & skull & 3 & 1933 & Jewett & Paleo \\
\hline & & skull & 3 & 1933 & Jewett & Paleo \\
\hline Harney Lake & $\begin{array}{l}\text { Wilbur Wright } \\
\text { (personal collection) }\end{array}$ & skull & 4 & 1930 & Wilbur & Paleo \\
\hline $\begin{array}{l}\text { Harney Dune } \\
\text { 35HA718 }\end{array}$ & $\begin{array}{l}\text { U.S. Fish and } \\
\text { Wildlife Service, } \\
\text { Portland Oregon }\end{array}$ & right mandible & 2 & 1991 & Raymond & Archaeo \\
\hline \multirow{2}{*}{$\begin{array}{l}\text { Roaring Springs } \\
\text { Cave 35HA433 }\end{array}$} & OSMA* & scapula & 2 & 1938 & Cressman & Archaeo \\
\hline & OSMA & radius & 2 & 1938 & Cressman & Archaeo \\
\hline unnamed 35GM91 & OSMA & $1^{\text {st }}$ phalanx & 3 & $?$ & Geo Recon. & Archaeo \\
\hline $\begin{array}{l}\text { Wildcat Canyon } \\
\text { 35GM9 }\end{array}$ & OSMA & scapula & 3 & $?$ & unknown & Archaeo \\
\hline \multirow{2}{*}{$\begin{array}{l}\text { Catlow Cave } \\
\text { 35HA405 }\end{array}$} & OSMA & humerus & 2 & 1938 & Cressman & Archaeo \\
\hline & OSMA & scapula & 3 & 1938 & Cressman & Archaeo \\
\hline $\begin{array}{l}\text { Paisley Cave } \\
35 \text { LK } 3400\end{array}$ & OSMA & patella & 4 & 2002 & Jenkins & Archaeo \\
\hline
\end{tabular}

$\pm \quad$ *OSMA refers to the Oregon State Museum of Anthropology. 
Theoretically, AMS dating procedures result in more precise and accurate bone dates than standard radiocarbon dating methods. AMS $\mathrm{C}^{14}$ dating can be accomplished using very small samples of highly purified bone compounds. Conventional $\mathrm{C}^{14}$ dating techniques do not allow for such precision and often result in the loss of large samples and inaccurate bone dates. For this project, bone dates that were published before the advent of AMS dating (early 1980's) were accepted with caution, and only accepted if other dating techniques were used in conjunction with radiometric dating.

Error in the $\mathrm{C}^{14}$ dating process does exist, and bone dating has its limitations as a result of factors acting on the bone itself and laboratory error. During the taphonomic process, bones go through a series of chemical and physical changes. These often result in the degradation of bone collagen and contamination of the bone by secondary carbonates. The pretreatment method used by both laboratories in this research project targets these secondary carbons and attempts to eliminate them.

The process of $\mathrm{C}^{14}$ dating is a complicated one and therefore research projects using $\mathrm{C}^{14}$ ages to answer questions of temporal chronology should be wary of the inherent difficulties of obtaining accurate dates from bone samples. Minimally, all information regarding the collection, sampling, pretreatment, calibration, and all results from the laboratory should be included in the report. This will allow future researchers to compare methods and assess the results based upon their own criteria for $\mathrm{C}^{14}$ dating validity. 


\section{Chapter 4 Results}

Archival Research Results

A total of 136 archaeological site reports were reviewed during background research for this project. Of these site reports, 102 included at least some discussion of faunal analysis, and 20 provide evidence of bison or possible bison (Table 4.1). Paleontological reports were reviewed as well, yet these were more difficult to evaluate for very few have adequate location information, and none have ever been tested for age. Figure 4.1 and 4.2 show the distribution of archaeological sites reviewed by county.

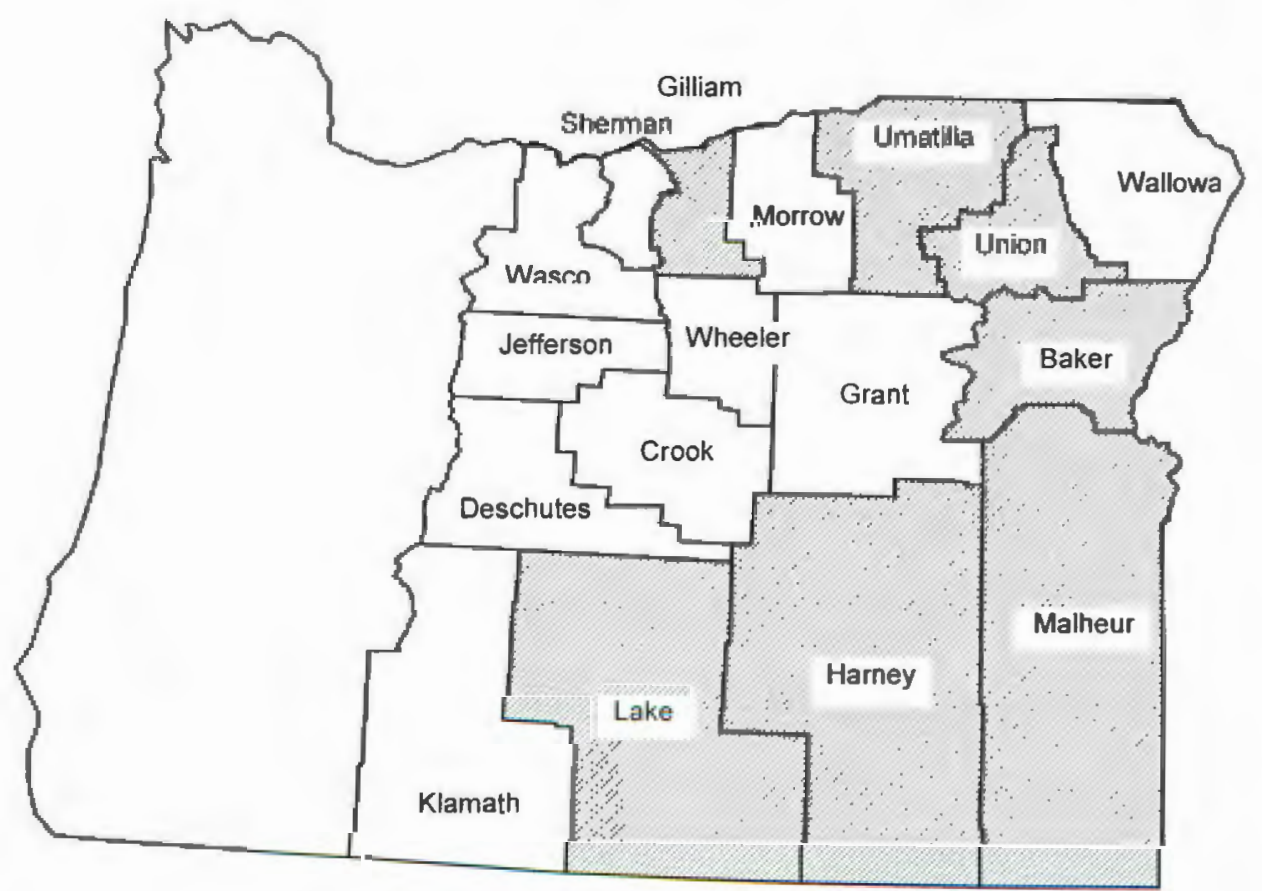

Figure 4.1 Counties with bison locales and possible bison locales. Shaing indicates counties with archaeological and/or paleontological bison remains. 


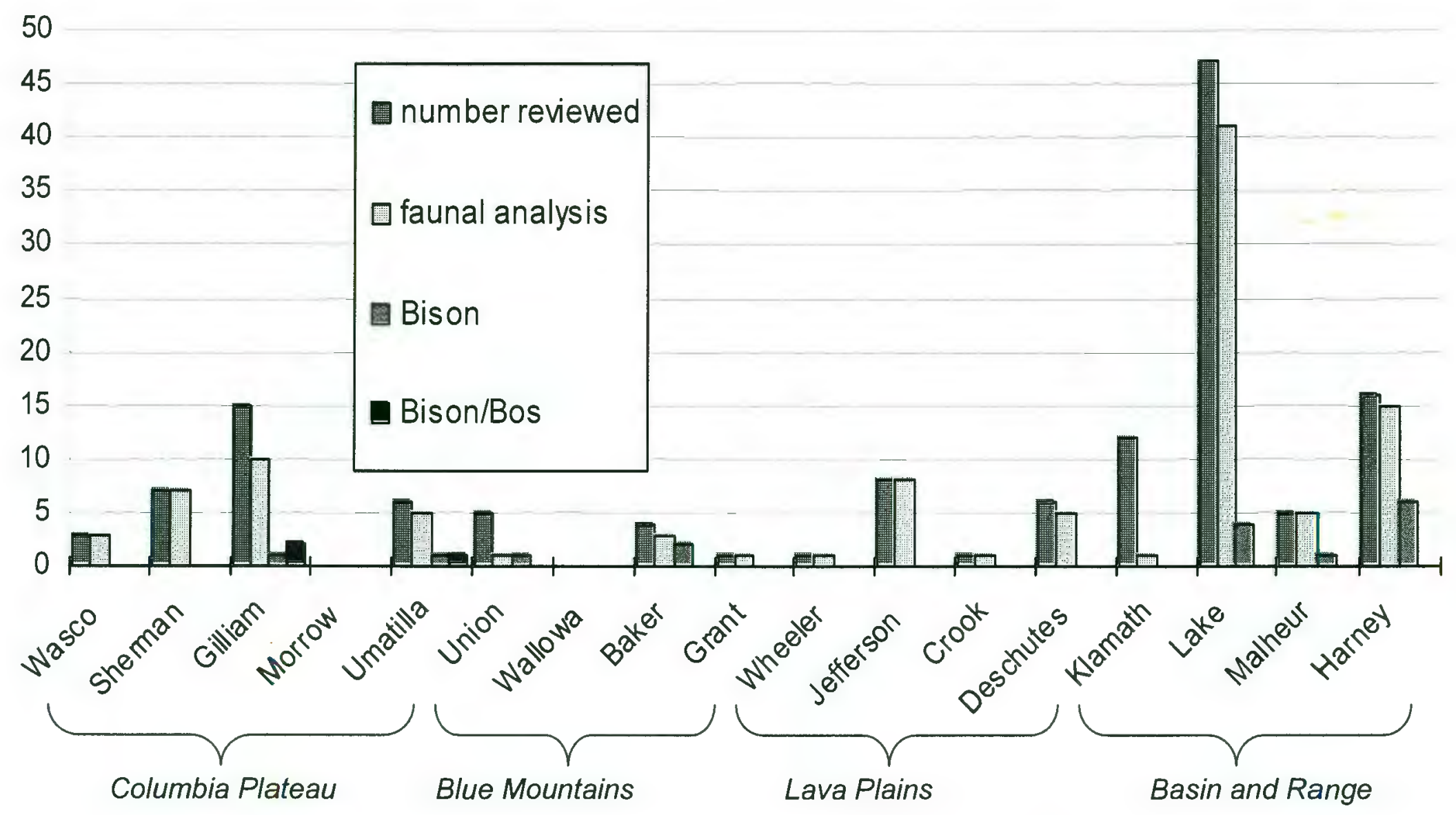

Figure 4.2 Distribution of archaeological sites reviewed by county and physiographic region, including number of sites with faunal analysis and number with Bison or Bison/Bos remains. 
The amount of archaeological and paleontological research varies across regions of eastern Oregon. The Basin and Range and Columbia Plateau are probably the physiographic regions with the most investigations. My data suggests that these two regions also have the greatest number of locales containing identified Bison and Bison/Bos specimens (Figure 4.2). The Blue Mountains contain the next greatest number of bison locales, and no records of bison were encountered from the Lava Plains region. This may be due to inappropriate habitat for bison in this region, or fewer investigations of archaeological sites.

Archaeological reports from Wallowa and Morrow counties were not reviewed for this study. References to archaeological sites in these counties were not often encountered in the published literature. Results from archival research indicate, however, that a sampling strategy for encountering bison records need not encompass all counties in eastern Oregon. Given the importance of bison to prehistoric people and the current debates over their abundance in the region, it is to be expected that reports from archaeological sites containing bison remains are more likely to be published. This can account for the infrequency of bison identifications in counties with less intensive archaeological investigations such as Union and Baker counties.

Research at most archaeological locales included in my study provided chronological information, but some records were inadequate for determining bison chronology. These are sites where disturbance of deposits, or a lack of datable 
materials, prevents assignment of bison to time periods. These sites were not included in my overall review of bison temporal distribution (Table 4.1).

The overall abundance of bison from archaeofaunal and paleontological assemblages in eastern Oregon is difficult to determine given the limited data pertaining to quantification available in the literature. NISP was available for all but the following three locales: Connley Caves, Paisley Caves, and Roaring Springs Cave. I have arbitrarily assigned an NISP of four to Roaring Springs Cave based on recent work with the faunal assemblage. Paisley Caves was assigned an NISP of 1 , however work continues at this site, and a report is forthcoming which will include data regarding the entire faunal assemblage (Jenkins personal communication 2003). Connley Caves remains the only site with no abundance data, and therefore I excluded it from discussions of bison abundance. The following review of archaeological and paleontological site reports discusses bison abundance and chronology in eastern Oregon (Table 4.1, Figure 4.3). 
Table 4.1 Archaeological bison in eastern Oregon. Highlighted locales are not included in final discussion of bison (see text for discussion).

\begin{tabular}{|c|c|c|c|c|c|c|}
\hline Locale & Bison Context & NISP & Age Estimate & Dating Method & Comments & References \\
\hline $\begin{array}{l}\text { Catlow Cave } \\
35 \text { HA405 }\end{array}$ & levels I and II & 24 & $\sim 1,000-3,000 \mathrm{BP}$ & $\begin{array}{l}\text { associated } \\
\text { projectile points }\end{array}$ & $\begin{array}{l}\text { Desert Side Notch and Rosegate } \\
\text { Points. Additional dates from this } \\
\text { study (see results) }\end{array}$ & $\begin{array}{l}\text { Cressman et al. } \\
1940\end{array}$ \\
\hline $\begin{array}{l}\text { Harney Dune } \\
35 \text { HA718 }\end{array}$ & surface & 3 & $\sim 250 \mathrm{BP}$ & $\mathrm{C}^{14}$ bone date & bone date from a bison skull & $\begin{array}{l}\text { Mehringer } \\
\text { (pers.comm.); } \\
\text { Raymond 1991 }\end{array}$ \\
\hline $\begin{array}{l}\text { Juniper Lake } \\
35 \mathrm{HA} 22\end{array}$ & surface & 4 & $4,000-8,000$ & associated artifacts & $\begin{array}{l}\text { age estimates are for the stratified } \\
\text { site not the bison remains. } \\
\text { Additional dates from this study } \\
\text { (see results) }\end{array}$ & Thomas 2002 \\
\hline $\begin{array}{l}\text { Roaring } \\
\text { Springs Cave } \\
\text { 35HA433 }\end{array}$ & not available & $4^{*}$ & not available & $\mathrm{n} / \mathrm{a}$ & $\begin{array}{l}\text { Bison listed in a table with no } \\
\text { provenience or chronology. *NISP } \\
\text { values assigned arbitrarily from } \\
\text { recent research on the faunal } \\
\text { assemblage. Additional dates from } \\
\text { this study (see results) }\end{array}$ & Cressmann 1942 \\
\hline $\begin{array}{l}\text { Skull Creek } \\
\text { Dunes } \\
\text { 35HA496 }\end{array}$ & $\begin{array}{l}\text { surface and } \\
\text { within } \\
\text { a midden }\end{array}$ & 6 & $-450 \mathrm{BP}$ & $\mathrm{C}^{14}$ bone date & Dated specimen is a skull & $\begin{array}{l}\text { Mehringer (pers. } \\
\text { comm..); } \\
\text { Wegener } 1998\end{array}$ \\
\hline \multirow{2}{*}{$\begin{array}{l}\text { Lost Dune } \\
\text { 35HA792 }\end{array}$} & surface & 1 & $\sim 450 \mathrm{BP}$ & $\mathrm{C}^{14}$ bone date & & \multirow{2}{*}{$\begin{array}{l}\text { Thomas 1983; } \\
\text { Mehringer (pers. } \\
\text { comm.); } \\
\text { Lyons } 2001\end{array}$} \\
\hline & surface & $?$ & $312-462 \mathrm{BP}$ & $\begin{array}{l}\mathrm{C}^{14} \text { associated } \\
\text { materials }\end{array}$ & & \\
\hline \multirow{3}{*}{$\begin{array}{l}\text { Connley } \\
\text { Caves \#4b } \\
35 \text { LK50 }\end{array}$} & $\begin{array}{l}\text { level } 32 \text { : large } \\
\text { bovid }\end{array}$ & $?$ & $12,836-13,518 \mathrm{BP}$ & \multirow{3}{*}{$\begin{array}{l}\mathrm{C}^{14} \text { charcoal in } \\
\text { association with } \\
\text { bison }\end{array}$} & & \multirow[t]{3}{*}{ Bedwell 1973} \\
\hline & level 34: Bison & $?$ & $10,482-11,566 \mathrm{BP}$ & & & \\
\hline & level 35: Bison & $?$ & not available & & & \\
\hline $\begin{array}{l}\text { Connley } \\
\text { Caves \#5b } \\
35 \text { LK50 } \\
\end{array}$ & $\begin{array}{l}\text { level 27: large } \\
\text { bovid }\end{array}$ & $?$ & $7,945-8,454 \mathrm{BP}$ & $\begin{array}{l}\mathrm{C}^{14} \text { charcoal in } \\
\text { association }\end{array}$ & & Bedwell 1973 \\
\hline
\end{tabular}


Table 4.1 Continued

\begin{tabular}{|c|c|c|c|c|c|c|}
\hline $\begin{array}{l}\text { Cougat Mt Cave } \\
35 \mathrm{LK} 55\end{array}$ & $\begin{array}{l}\text { bottom } 2 \text { feet of } \\
\text { cave \#1 }\end{array}$ & $?$ & not available & $\mathrm{n} / \mathrm{a}$ & $\begin{array}{l}\text { cave } \# 2 \text { reported by } \\
\text { Bedwell (1973) no bison } \\
\text { reported }\end{array}$ & Cowles 1960 \\
\hline $\begin{array}{l}\text { Fort Rock Cave } \\
351 \mathrm{~K} 1\end{array}$ & $\begin{array}{l}\text { unspecified } \\
\text { bovid in layer } 1\end{array}$ & $?$ & not available & $\mathrm{n} / \mathrm{a}$ & $\begin{array}{l}\text { Cressman lists bison in a } \\
\text { table (1942: 144) but } \\
\text { provides no provenience or } \\
\text { chronology }\end{array}$ & $\begin{array}{l}\text { Cressman 1942; } \\
\text { Bedwell } 1973\end{array}$ \\
\hline \multirow[t]{2}{*}{$\begin{array}{l}\text { Paisley Caves } \\
\text { 35LK3400 }\end{array}$} & $\begin{array}{l}\text { cave \#3 (lower } \\
\text { occupation layer) }\end{array}$ & $?$ & not available & $\mathrm{n} / \mathrm{a}$ & & $\begin{array}{l}\text { Cressman et al. } \\
1940 \text {; Cressman } \\
1942\end{array}$ \\
\hline & cave \# 2, level 5 & 1 & $\sim 1,000-3,000 \mathrm{BP}$ & $\begin{array}{l}\text { diagnostic artifact } \\
\text { association } \\
\text { (Rosegate Points) }\end{array}$ & $\begin{array}{l}\text { This bone was sampled } \\
\text { during this study (see } \\
\text { results) }\end{array}$ & $\begin{array}{l}\text { Jenkins (pers. } \\
\text { comm.) }\end{array}$ \\
\hline \multirow{4}{*}{$\begin{array}{l}\text { Dirty Shame } \\
\text { Rockshelter } \\
\text { 35ML65 }\end{array}$} & $\begin{array}{l}\text { zone I: } \\
\text { (Bison/Bos) }\end{array}$ & 144 & $400-1100 \mathrm{BP}$ & \multirow{4}{*}{$\begin{array}{l}\mathrm{C}^{14} \text { charcoal in } \\
\text { association with } \\
\text { bison }\end{array}$} & & \multirow[t]{4}{*}{$\begin{array}{l}\text { Aikens et al. 1977; } \\
\text { Grayson } 1977\end{array}$} \\
\hline & $\begin{array}{l}\text { zone II: } \\
\text { (Bison/Bos) }\end{array}$ & 2 & $1100-2700 \mathrm{BP}$ & & & \\
\hline & $\begin{array}{l}\text { zone IV:(Bison } \\
\text { antiquus) }\end{array}$ & 4 & $6300-6800 \mathrm{BP}$ & & & \\
\hline & $\begin{array}{l}\text { zone V:(Bison } \\
\text { antiquus) }\end{array}$ & 6 & $6800-7900 \mathrm{BP}$ & & & \\
\hline $\begin{array}{l}\text { Paulina Lake } \\
\text { 35DS34 }\end{array}$ & see comments & $n / a$ & $8,560-10,040$ & $\begin{array}{l}\mathrm{C}^{14} \text { materials in } \\
\text { association with } \\
\text { lithic materials } \\
\text { tested for bovine } \\
\text { antiserum }\end{array}$ & $\begin{array}{l}\text { No bison remains, yet blood } \\
\text { residue analysis of lithic } \\
\text { tools positive for bovine } \\
\text { antiserum. }\end{array}$ & Connolly 1999 \\
\hline \multirow[t]{2}{*}{$35 \mathrm{UN} 80$} & Bison & 4 & \multirow[t]{2}{*}{$\sim 200-1,000 \mathrm{BP}$} & \multirow[t]{2}{*}{ associated artifacts } & \multirow[t]{2}{*}{ Desert Side Notch Points } & \multirow{2}{*}{$\begin{array}{l}\text { Francy 1976; } \\
\text { Lyman 1980 }\end{array}$} \\
\hline & Bison/Cervus & 2 & & & & \\
\hline $\begin{array}{l}\text { Robinetie Cave } \\
\text { 35BAS }\end{array}$ & not available & 3 & not available & $\mathrm{n} / \mathrm{a}$ & $\begin{array}{l}\text { Excavated to } 8 \mathrm{ft} \text {., historic } \\
\text { artifacts found throughout }\end{array}$ & $\begin{array}{l}\text { Caldwell 1967; } \\
\text { Schroed1 1973 }\end{array}$ \\
\hline
\end{tabular}


Table 4.1 Continued

\begin{tabular}{|c|c|c|c|c|c|c|}
\hline $\begin{array}{l}\text { The Ray } \\
\text { site } \\
35 \mathrm{~B} A 23\end{array}$ & not available & 1 & not available & $n / a$ & & $\begin{array}{l}\text { Caldwell 1967; } \\
\text { Schroedl } 1973\end{array}$ \\
\hline $\begin{array}{l}\text { Techumias } \\
\text { Island } \\
\text { 35UM17 }\end{array}$ & $2-4.5 \mathrm{ft}$. below surface & 5 & pre-contact & diagnostic artifacts & $\begin{array}{l}\text { Site is now under water } \\
\text { due to dam construction }\end{array}$ & Osborne 1953 \\
\hline \multirow[t]{2}{*}{$35 \mathrm{UM} 1$} & $\begin{array}{l}\text { Unit N40/E520 Bison/ } \\
\text { Bos }\end{array}$ & 1 & $\begin{array}{l}1,686-2,012 \\
\text { BP }\end{array}$ & $\begin{array}{l}\mathrm{C}^{14} \text { charcoal in } \\
\text { association with } \\
\text { bison }\end{array}$ & & \multirow[t]{2}{*}{ Schalk 1980} \\
\hline & $\begin{array}{l}\text { Unit Noo/E560 Bison/ } \\
\text { Bos }\end{array}$ & 1 & not available & $\mathrm{n} / \mathrm{a}$ & & \\
\hline \multirow[t]{5}{*}{$\begin{array}{l}\text { Wildcat } \\
\text { Canyon } \\
35 \text { GM9 }\end{array}$} & Area 2:strata C & 19 & $\begin{array}{l}1,171-1,423 \\
\mathrm{BP}\end{array}$ & $\begin{array}{l}\mathrm{C}^{14} \text { charcoal in } \\
\text { association with } \\
\text { bison }\end{array}$ & & \multirow{5}{*}{$\begin{array}{l}\text { Cole 1967; } \\
\text { Dumond and } \\
\text { Minor 1983; } \\
\text { Schroedl } 1973\end{array}$} \\
\hline & Area 2:strata D & $8^{*}$ & $\begin{array}{l}2,957-4,301 \\
\text { BP }\end{array}$ & $\begin{array}{l}\mathrm{C}^{14} \text { charcoal in } \\
\text { association with } \\
\text { bison }\end{array}$ & $\begin{array}{l}\text { Date may be in error } \\
\text { (Schroedl 1973). Date } \\
\text { not included in final bison } \\
\text { chronology. *NISP } \\
\text { values derived by adding } \\
\text { results from Cole } 1967 \\
\text { and Dumond and Minor } \\
1983\end{array}$ & \\
\hline & $\begin{array}{l}\text { Area 5:strata A (above } \\
\text { ash) }\end{array}$ & 3 & not available & & & \\
\hline & $\begin{array}{l}\text { Area 5:strata B (above } \\
\text { ash) }\end{array}$ & 2 & not available & & & \\
\hline & $\begin{array}{l}\text { Area 5:strata D (above } \\
\text { ash) }\end{array}$ & 25 & not available & & & \\
\hline
\end{tabular}


Table 4.1 Continued

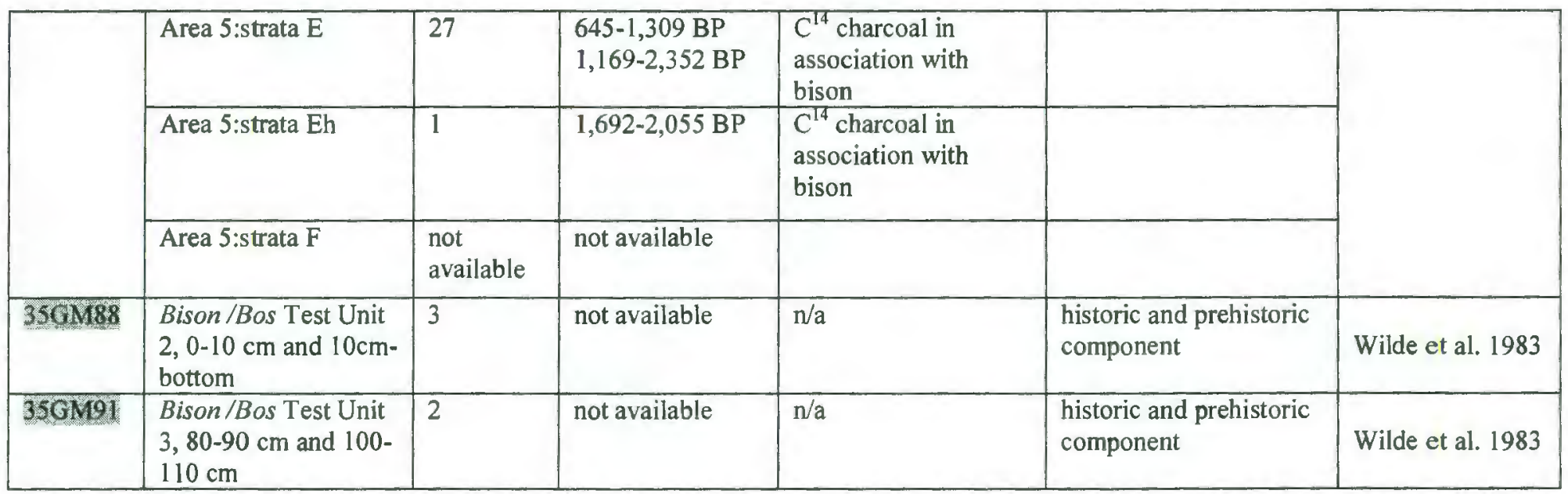




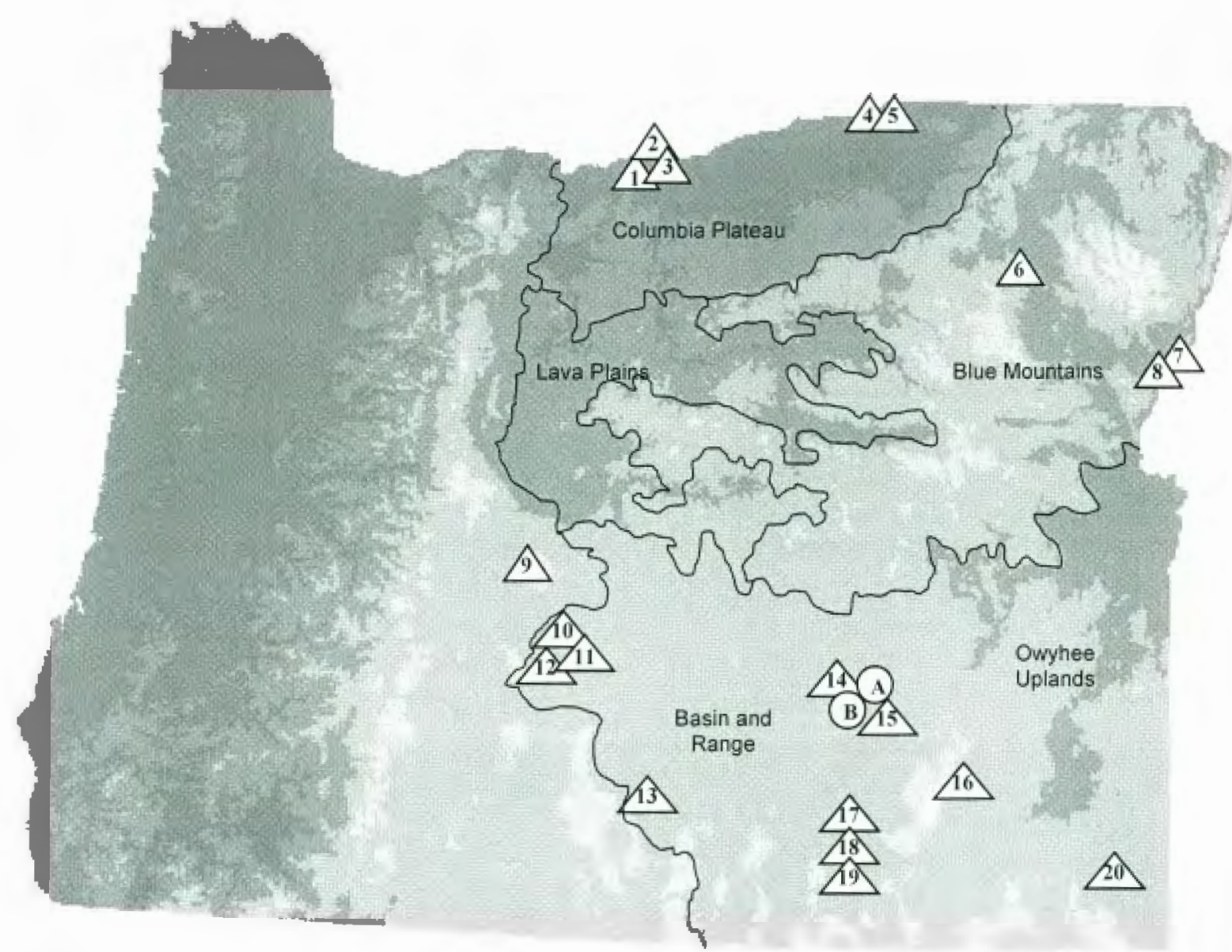

Figure 4.3 Locations of archaeological and paleontological bison locales in eastern Oregon. $\triangle$ Archaeological Sites

$135 \mathrm{GM} 91$

2 35GM92

3 Wildcat Canyon (35GM9)

4 Techumtas Island (35UM17)

5 Umatilla Site (35UM1)

635 UN80

7 The Ray Site (35BA23)

8 Robinette Cave (35BA3)

9 Paulina Lake (35DS34)

10 Fort Rock Cave (35LK1)

11 Cougar Mt. Caves (35LK55)

12 Connley Caves (35LK50)

13 Paisley Caves (35LK3400)

14 Harney Dune (35HA718)

15 Lost Dune (35HA792)

16 Juniper Lake (35HA22)

17 Catlow Cave (35HA 405)

18 Skull Creek Dunes (35HA492)

19 Roaring Sps. Cave (35HA433)

20 Dirty Shame Rkshltr (35ML65)

Paleontological Sites

A Malheur Lake B Harney Lake 


\section{Columbia Plateau}

Five sites in the eastern Oregon Columbia Plateau discuss the recovery of bison remains from buried deposits. The most substantial bison bone recovery occurred at Wildcat Canyon (35GM9). A total of 70 bison skeletal remains were obtained from areas 2, 5, and 6 (Cole 1968; Schroedl 1973). Several radiocarbon dates were collected from deposits containing bison skeletal remains. Ages range from 1,309-645 $\mathrm{BP}$ and 4,301-2,957 BP. The later age range comes directly from a bison bone collected in stratum D of area 2. Schroedl (1973) notes that the laboratory which supplied this date was not confident in the date due to low carbon content of the bone. Artifacts in association with this bone support an age of $\sim 2,000$ Cal B.P (Cole 1968). I chose not to accept the bison bone date and rather to rely on other radiocarbon dates and dates on associated artifactsnot considered in error.

Another site discussed by Schroedl is Techumtas Island (35UM17) (Schroedl 1973). Osborne participated in the original excavation of the site and reported a total of 5 unspecified bison elements from 2 housepits (Osborne 1953). The bones were found between 2 and 4.5 feet below the surface. Radiocarbon dating was not done at Techumtas Island, and the stratigraphy was not described (Osborne 1953). A late pre-contact age of the site was suggested by Shiner, based on associated artifacts (1952).

The site report on file at the Oregon State Office of Historic Preservation mentions that in 1999, surveyors were unable to relocate the site because 
construction of dams along the Columbia River resulted in flooding of the site. The current location of faunal remains from Techumtas Island is unknown. Due to a lack of confidence in chronology, and little descriptive data regarding stratigraphy, Techumtas Island will not be considered in my final discussion of bison locales.

Two sites in Gilliam county were reported to have bison remains in a study by Geo-Recon International in 1983 (Wilde et al. 1983). 35GM88 is described as a large scatter of prehistoric and historic artifacts. Several test units were dug to establish the depth of the site. One element of a large mammal identified as Bison/Bos was recovered in the uppermost level of the site $(0-10 \mathrm{~cm})$, and two elements were discovered in the lowest layers of the site (10 cm-bottom). 35GM91 is described as a rapidly eroding multi-component prehistoric and historic habitation site. Two elements identified as Bison/Bos were recovered from the site. One was found at $80-90 \mathrm{~cm}$ and the other at $100-110 \mathrm{~cm}$. A bone sample from 35GM91 was tested for radiocarbon dating during this study. Due to degraded collagen, a date could not be obtained from the sample. Since no chronological information is available for 35GM91 and 35GM88, they were eliminated from my final sample of bison locales.

35UM1 is located within the city limits of Umatilla. Unspecified Bison/Bos elements were recorded from two different components at 35UM1. One component containing Bison/Bos yielded a radiocarbon age of 2,012-1,686 BP (Schalk 1980). Radiocarbon ages for the site range from 3,680-60 BP. Artifacts and suggested ages of 35UM1 are similar to those from Wildcat Canyon. 
Blue Mountains

35UN80 is located in the foothills of the Blue Mountains in the Grande Ronde Valley. The site was tested by Francy in 1976, who described the site as a "buffalo jump" (Francy 1976). Bison remains were collected from a midden-like deposit at the base of a columnar basalt cliff. A total of four unspecified skeletal elements were identified as Bison bison and two others were identified as Bison or Cervus (elk) (Fields 1976, Lyman 1980). Several other elements were collected at the site, but these were too badly burned or fragmented to make even tentative identifications. Artifacts found in association with bison remains include Desert Side Notched projectile points, suggesting a late Holocene (specifically 1,500-200 BP) bison kill event (Francy 1976).

Two sites located in Baker County along the border of Oregon and Idaho were reported to contain bison skeletal remains (Schroedl 1973). The Ray site (35BA23) and Robinette Cave (35BA3) are located along the Snake River in Baker County. Both sites are described as prehistoric sites containing bison remains. No information regarding the provenience or chronology of the bison remains is available for either site. The current location of the faunal remains from both sites is unknown. Schroedl eliminated both sites from his sample, based on disturbed strata and lack of diagnostic artifacts (Schroedl 1973). These sites will not be included in my final tally of bison locales. 


\section{Basin and Range}

Basin and Range is the physiographic region of eastern Oregon most intensively studied by archaeologists. Several archaeological sites in this region were excavated in the late 1930's by Luther Cressman (Cressman et al. 1940; Cressman 1942). Among the sites first excavated by Cressman, several were reported to contain the skeletal remains of bison. More recent work has expanded the list of bison locales in this region (Bedwell 1973; Jenkins personal communication 2003; Lyons 2000; Thomas 1983; Wegener 1998).

Fort Rock Cave (35LK1) was first excavated by Cressman in 1938 (Cressman et al. 1940; Cressman 1942). Cressman listed bison remains in a table (Cressman 1942: 144), but information regarding provenience, number of specimens, and elements was lacking. Bedwell (1973) reported unspecified bovid remains in layer 1 of Fort Rock Cave. There was no radiocarbon date listed for this occupation layer in Bedwell's paper, and the stratigraphic provenience is also unclear. Further research is necessary at Fort Rock Cave to determine the presence and chronology of bison. Fort Rock Cave will not be included in my final discussion of bison locales.

Cougar Mountain Caves (35LK55) are located 10 miles southeast of Fort Rock Cave. In 1958, an amateur archaeologist, Cowles, dug Cave number 1 (Cowles 1960). He reported bison remains from the bottom two feet of the cave. Bedwell (1973), in his review of Fort Rock Basin archaeology, suggests that the stratigraphy of Cougar Mountain Cave is similar to that of Fort Rock Cave. The 
stratigraphy is also similar to that of Cougar Mountain Cave Number 2, also tested by Bedwell (1973). Charcoal from Cave number 2 yielded an age of to 13,000 BP (Bedwell 1973). However, radiocarbon ages were not produced from Cougar Mountain Cave number 1 deposits, where bison remains were reportedly found, therefore, the antiquity of bison at this site remains ambiguous. Cougar Mountain Caves will not be included in my final discussion of bison locales.

De Gorma Cave and Plush Cave are also listed as sites with bison remains by Cressman (1942: 144), yet no details of the discoveries are provided in the report. Likewise, I was unable to find other published reports discussing the contents of these caves, so the presence of bison from these locales remains speculative. Neither of these sites will be included in my final discussion of bison locales.

Connley Caves (35LK50) are also located in the Fort Rock Basin at an elevation and setting that is similar to that of the previously mentioned caves. Connley Caves was occupied before 7,000 BP (Bedwell 1973); as evidenced by human artifacts lying in and below a Mazama ash lens, which has been dated to roughly 7,500 BP. Also found below the Mazama ash lens were the remains of bison (Bedwell 1973). Unspecified bison elements were found in cave $4 \mathrm{~b}$ in levels 34 and 35. A charcoal sample from level 35 yielded a radiocarbon age of 13,51812,936 BP. Another sample from level 34 was aged 11,566-10,482 BP. Unspecified large bovids are also listed in cave $4 \mathrm{~b}$ and $5 \mathrm{~b}$ in layers below the 
Mazama ash lens. Bedwell (1973) reported no bison in the upper occupation layers.

Recent work at Connley Caves resulted in the discovery of large mammal, possibly Bison or Bos in layers above the Mazama ash lens (Jenkins personal communication 2003). These bones may represent the late Holocene presence of bison at Connley Caves, but radiocarbon dates are not currently available. Information regarding bison NISP and elements present are currently lacking for Connley Caves. Further work at the locale is necessary to assess the complete sample of bison faunal remains and establish the late Holocene presence of bison at this locale.

Paisley Caves are a series of several caves overlooking Summer Lake. Cressman supervised excavations here in 1938 (Cressman et al. 1940; Cressman 1942). His findings suggested that Paisley Caves may have been occupied as soon as it became habitable, at the beginning of the Holocene when Summer Lake's waters receded to allow access to the caves. Cressman claims that bison, horse, and camel bones were found in the lower occupation levels of Cave Number 3 . Cressman suggested these faunal remains were possibly older than $9,000 \mathrm{BP}$ (Cressman et al. 1942). Recent work at Cave Number 2 resulted in the discovery of more camel, horse, and bison bones (Jenkins personal communication 2003). The patella of an adult bison (most likely male) was found in level 5 of the cave. Artifacts from this same level include several Rose Spring projectile points, which 
suggests late Holocene deposition. The patella was selected for radiocarbon dating during this study; the results will be discussed in detail in the following section.

Paulina Lake (35DS34) is a site located in Deschutes County just along the periphery of the Great Basin. Though no bison remains were recovered from the site, blood residue analysis of obsidian artifacts indicate a positive match for bovine antiserum (Connolly 1999). Bovine antiserum represents a match for all bovines which includes Bison and Bos. The artifacts from which the blood residues were collected were found in cultural component 2 and 3, which have radiocarbon dates ranging from $6540+/-150 \mathrm{BP}$ to $7560+/-190 \mathrm{BP}$ in component 3 and $7930+/-80$ $\mathrm{BP}$ to $9060+/-80 \mathrm{BP}$ in component 2 . Though not as valuable as a positively identified bison bone, these data are relevant to the study and potentially helpful in encouraging further research at Paulina Lake. Because bison remains were not collected from Paulina Lake, it will not be included in my final discussion of bison locales.

Catlow Cave (35HA405), a rockshelter located in the Catlow Valley, was first excavated in 1935 by Luther Cressman (Cressman et al. 1940; Cressman 1942). At this time Cressman noted the damage already done to the site by pothunters and vandals. Cressman noted that there is no clear cultural or geologic stratigraphy for Catlow Cave. Radiocarbon dates were not available because the site was excavated before the advent of radiometric dating. Cressman suggested that the earliest deposits at Catlow and other caves in the region represent the material remains of early Holocene hunters and gatherers (Cressman et al. 1940). 
These deposits contained a large percentage of waterfowl, indicative of lacustrine and wetland environments. Later deposits contained a higher percentage of mammals, including bison.

A later analysis of projectile point types and comparison with radiometric dating from other Great Basin cave sites provides a clearer chronology of Catlow Cave and other cave sites in eastern Oregon (Aikens 1993; Wilde 1985). Wilde suggests that components containing Elko Eared and Corner Notched points as well as Great Basin Stemmed points represent occupation between 7,000 and 3,000 BP. There were no bison bones found in these deeper layers of the cave; however, bison remains were found in layers containing Rosegate Points $(-3,000-1,000 \mathrm{BP})$ and Desert Side Notched Points ( 1,500-200 BP).

Roaring Springs Cave, located only 30 miles from Catlow Cave was also excavated by Cressman in the 1930s (Cressman et al. 1940). Similar stratigraphy and artifact assemblages were found at Roaring Springs Cave and Catlow Cave. Cressman lists bison in a table for Roaring Springs Cave, but does not mention the provenience. Also included in Cressman's (1942) summary of artifacts for Roaring Springs Cave are bison hide moccasins found on the surface in the back of the cave.

Artifacts and faunal remains collected during Cressman's early field work for both Catlow Cave and Roaring Springs Cave are curated at the Oregon State Museum of Anthropology. At the time of my investigation, no follow up work had been done on the faunal materials collected by Cressman at these sites. During a 
trip to the Oregon State Museum of Anthropology, three boxes containing faunal remains from the two sites were examined. Five bison bones were identified from Catlow Cave and four from Roaring Springs Cave (Appendix A). It is not known if these collections represent the entire faunal assemblage from the two sites, so total bison NISP could not be determined. Cressman listed 24 bison elements in levels I and II at Catlow Cave (Cressman et al. 1940), however no NISP value was given for Roaring Springs Cave. For the purposes of this study, the number of bones from Roaring Springs Cave documented during the most recent museum visit will be considered valid NISP values (Table 4.1). Two samples from Roaring Springs Cave and Catlow Cave were selected for radiocarbon dating. The results of these are discussed in detail below.

Recent work in Harney County has resulted in the discovery of several more sites containing bison remains. Harney Dune (35HA718) is located along the north and west edge of Harney Lake. The dune system is 11.25 kilometers long and runs from 1 to 13 meters in elevation above the lake shore. The archaeological site (35HA718) was first recorded in the 1970's by Portland State University students. After high lake levels in the 1980's receded, water erosion exposed more of the site than was visible during the 1970 surveys.

Archaeologists believe natural sand dune formation encapsulated surface features and as the sand slowly eroded away, the site became visible. Work at Harney Dune has been limited to surface collections, however Raymond (1994) suggests that older assemblages may still be buried on the north and west end of the 
dune. Several occupation periods were suggested by Raymond (1994) as evidenced by the presence of projectile point forms suggestive of early $(8,000$ $6,000 \mathrm{BP})$ and late ( 1,500 B.P-historic period) artifact assemblages.

Three possible bison elements were collected at Harney Dune (Raymond 1994). One of these, a skull fragment sent off for radiocarbon dating as part of previous research, yielded a date of $250 \mathrm{BP}$ (Mehringer personal communication 1999). The other elements recovered at Harney Dune include a mandible fragment and a horn core fragment (Raymond 1994). The mandible was selected for radiocarbon dating; results will be discussed in detail in the following section.

Positive identifications of bison were made at another site in the Harney Basin. Lost Dune (35HA792) is a unique site for the area in that several Paiute/Shoshone pottery fragments were recorded (Lyons 2001; Thomas 1983). Projectile points collected at the site indicate at least two occupation periods. The earlier component (3,000 BP) is represented by Humboldt and Elko series projectile points. The later (more recent) component consists of Desert Sidenotched and Rose Spring corner notched points.

A bison skull was found on the surface at Lost Dune, associated with prehistoric artifacts. Radiocarbon dating of this bone yielded a date of $450 \mathrm{BP}$ (Mehringer personal communication 1999; Thomas 1983).

Another dune site in eastern Oregon with similarly aged bison remains is Skull Creek Dunes (35HA496). A total of 32,116 faunal remains were collected from surface and stratified deposits, including 4 elements identified as Bison or Bos 
and 1 element identified as Bison or Cervus (elk) (Wegener 1998). During a previous investigation of the site, a bison skull was collected from the surface. Information regarding the collection of this element has not been published. Personal communication with Mehringer (1999) indicates that the bone was aged $\sim 450$ BP

Skull Creek Dune provides an excellent example of the scarcity of bison in eastern Oregon archaeofaunas. Of the 32,116 NISP, large-size Artiodactyl (Bison, Cervus, Bos) represent $0.4 \%$ of the total NISP for the site, and $2.2 \%$ of the total MNI. Rabbits (Lepus sp.) and medium sized Artiodactyl (deer, pronghorn, and sheep) are the most abundant species in the assemblage. The presence of tooth enamel and other elements representing low utility body parts indicates that bison were indeed procured near Skull Creek Dunes. However, quantification of the faunal assemblage indicates that they were procured in relatively small numbers.

Juniper Lake (35HA22) is an archaeological site located in the Alvord Desert in southeastern Oregon. Bison remains were collected from the surface of this site in 2001 (Thomas 2001). Juniper Lake contains deposits and stratigraphic context similar to Skull Creek Dunes. Artifacts at Juniper Lake were eroding from a dune approximately 8 meters high. Four large mammal bones identified as Bison bison were found at the surface of the dune (Thomas personal communication 2002), including one fragmented scapula, a horn core, and one left and right distal femur of a juvenile. Projectile point types found at Juniper Lake include Rosegate Corner Notched and Elko Eared and Corner Notched points. Thomas suggests that 
the site may contain cultural deposits ranging in age from $8,000 \mathrm{BP}$ to $1,000 \mathrm{BP}$ based on similarities with other sites in the region and projectile point types (Thomas 2001). Three bison bones were sampled from Juniper Lake for radiocarbon dating. These results will be discussed further in the following section. The Headquarters Site (35HA403), located at the Malheur Wildlife Refuge headquarters yielded a "possible Bison" rib bone in level 10 of unit $\mathrm{E}$ (Dugas and Bullock 1994). During the bone documentation portion of this study, this bone was re-examined, and determined to be a radius fragment of a carnivore. Upon this discovery, the Headquarters Site was removed from the list of bison locales in eastern Oregon.

Dirty Shame Rockshelter (24ML65) located in the southeastern corner of Oregon shows evidence of human occupation in the early Holocene $(9,500-5,900$ BP) and the late Holocene (2,700-400 BP) (Aikens et al. 1977). Six cultural zones were assigned to deposits based on artifact types, stratigraphy, and radiocarbon dating (Table 4.2). 
Table 4.2 Cultural zones and associated radiocarbon ages for Dirty Shame Rockshelter (Aikens et al. 1977, Grayson 1977). Bison quantified using NISP and MNI.

\begin{tabular}{c|c|l} 
Zone & Radiocarbon ages (bracketed) & \multicolumn{1}{|c}{ Bison NISP and MNI } \\
\hline I & $400-1,100 \mathrm{BP}$ & $\begin{array}{l}\text { NISP 144 (Bison/Bos) } \\
\text { MNI 6 (Bison/Bos) }\end{array}$ \\
\hline II & $1,100-2,700 \mathrm{BP}$ & $\begin{array}{l}\text { NISP 2 (Bison/Bos) } \\
\text { MNI 2 (Bison/Bos) }\end{array}$ \\
\hline III & $5,900-6,300 \mathrm{BP}$ & \\
\hline IV & $6,300-6,800 \mathrm{BP}$ & $\begin{array}{l}\text { NISP 4 (Bison } \text { cf. antiquus) } \\
\text { MNI 1 (Bison/Bos) }\end{array}$ \\
\hline V & $6,800-7,900 \mathrm{BP}$ & $\begin{array}{l}\text { NISP 6 (Bison } \text { cf. antiquus) } \\
\text { MNI 3 (Bison cf. antiquus) }\end{array}$ \\
\hline VI & $7,900-9,500 \mathrm{BP}$ &
\end{tabular}

Grayson (1977) analyzed the mammalian and avian faunal remains from Dirty Shame Rockshelter. A total of 10 unspecified elements were identified as Bison sp. antiquus, and a total of 146 were identified as Bison or Bos. Bison represented $21 \%$ of the mammalian fauna in zone I and $0.01 \%$ of the mammalian fauna in zone II. Bison cf. antiquus was found in zones IV and V and represented $0.01 \%$ of the mammalian fauna in both these occupational zones. Bison are most abundant in the latest occupation zone (1,100-400 BP). The gap in occupation of the rockshelter between 5,900-2,700 BP as well as fluctuations in mammal abundance (including bison) was interpreted by Grayson (1977) as the result of climate change to drier, more uninhabitable climate during the middle Holocene.

Several paleontological sites have been recorded in eastern Oregon (Bailey 1923, 1933, 1936; Van Vuren and Bray 1985). Much of what is known about these locales is anecdotal. For the most part, provenience data are lacking or vague and chronological data are not available. As mentioned earlier, paleontological data 
provide evidence of bison presence independent of human subsistence activity. Therefore, documentation of these locales is especially important for understanding the paleoecology of bison in Oregon.

On November $1^{\text {st }} 1826$, Peter Skene Ogden noted in his journals that bison skulls were seen in the vicinity of Malheur and Harney lakes (Elliott 1910). 100 years later, accounts of bison skulls at these locales became a focal point for bison research in Oregon (Bailey 1923, 1932, 1936). Bailey (1932) reported on the skeletal remains of hundreds of adult (female and male) bison at Malheur Lake, suggesting there was a locally breeding herd in the region at one time. The cause of death for these bison is unknown, but Bailey suggested they mired in the mud of the lakes during low water years. Since Bailey's original reporting, only 30 of these specimens were tracked down for further research (Van Vuren and Bray 1985; Van Vuren personal communication 2003) (Appendix A).

Thirty adult bison skulls have been formally recorded from the Malheur Lake bone bed, yet no chronological information is available for these specimens. Several of the specimens have been documented and evaluated for species identifications. McDonald (1981) suggested that the average size of the bison recovered from Malheur Lake is larger than that of the average Plains bison. He also noted that $15 \%$ of the skulls showed skeletal abnormalities, which may indicate genetic drift or inbreeding of an isolated population.

Bailey (1932) originally described the Malheur Lake bison as an extinct sub-species of Bison bison, naming them Bison bison oregonus. This classification 
was based on skeletal morphology, most notably, skull size and horn core angle. It has since been determined that the bison found in eastern Oregon were probably isolated populations of Bison bison (McDonald 1981). McDonald noted that Plains bison often traveled across the Rocky Mountains and into the central Great Basin. Bison recovered from archaeological sites and paleontological sites in Oregon are likely dispersed Plains populations.

No other region in the Intermountain West has as many reported paleontological bison locales as eastern Oregon. The discovery of the bone bed at Malheur Lake spurred much interest on the subject of prehistoric bison in Oregon and local newspapers began to run articles discussing other bison finds (The Oregonian, 19 August 1928; 27 December 1930; 29 December 1930; 4 January 1931; 28 March 1931; 27 July 1931). Newspaper articles as well as recent research on bison in Oregon (Van Vuren and Bray 1985) reported several locales in eastern Oregon containing bison skeletal remains.

Bison were reported from near the town of Prineville, Deschutes County (Oregonian, 19 August 1928, Bailey 1923); Wallowa County (Oregonian, 29 December 1930); near the town of Oregon City (Ibid); The Blue Mountains (Bailey 1923); Cow Creek Lakes, Malheur County (Ibid.); three locales in Grant County, near the towns of Izee and Seneca, and near Flag Mountain (Van Vuren and Bray 1985); Joseph, Oregon (Van Vuren and Bray 1985); and recently reports of bison found on private property came to my attention. These include a ranch near Harney 
Lake (Bill Wilbur personal communication 2003); and property bordering Klamath Marsh (Steve Wert personal communication 2003).

Paleontological specimens from some of these locales are housed in museums and personal collections (Appendix A). Those housed in museums are most valuable to this study, for they have been properly curated and are documented in data bases. Those from personal collections are harder to document. Location information is also difficult to obtain for several of the paleontological locales mentioned in research papers and newspaper articles. For the purposes of this study, the specimens I chose for further documentation and radiocarbon dating come from two established paleontological locales with background literature, including historic accounts, to support them. These come from the Malheur Lake bone bed and from a ranch near Harney Lake. Results of radiocarbon dating from these locales will be discussed below.

\section{Summary of Archival Research Results}

A review of the archaeological literature provided evidence of bison or possible bison from 12 locales with adequate chronological data availablefor further discussion. Several paleontological locales were discussed in the literature, but only two were sampled during this study for radiocarbon dating. Thus far, archaeofaunal assemblages containing bison have been documented from cultural components dating to the early Holocene (Connley Caves, Dirty Shame Rockshelter) and the late Holocene (Harney Dune, Lost Dune, Paisley Caves, Skull Creek Dunes, Wildcat Canyon, 35UN80, and 35UM1). Radiocarbon dating of 
previously undated locales including Juniper Lake, Catlow Cave, and Roaring Springs Cave archaeological sites and Malheur and Harney Lakes paleontological samples will add to our current knowledge of bison chronology in eastern Oregon. Anthropological researchers have suggested that Native American hunters made logistical trips outside Oregon to procure bison (Anastasio 1972; Schroedl 1973). Thus, archaeofaunal bison assemblages may contain bison remains not procured locally. The presence of prehistoric bison from a context independent of human subsistence activity such as the Malheur Lake bone bed provides concrete evidence of the prehistoric presence of bison in eastern Oregon.

For many archaeological reports containing references to bison, skeletal element was not specified. Though none of the bison skeletal remains recovered were described in the literature as formed artifacts that may have been traded long distances, it remains possible that some skeletal elements representing high value body parts were brought into Oregon from outside. Regardless, I have accepted all bison archaeofaunal contexts as locally procured bison. Further research may be needed to support or refute this assumpion.

\section{Radiocarbon Dating Results}

Attempts were made to obtain $\mathrm{C}^{14}$ ages for 17 bone samples, but due to low amounts of collagen, two samples could not be graphitized and therefore could not be aged. Of the remaining 15 samples, five yielded problematic dates deserving discussion. Four of these were recent dates, overlapping with the historic period in Oregon, and one is potentially too old as a result of error in the dating process. The 
following reviews the radiocarbon dating results from eastern Oregon bison bones (Table 4.3, Figure 4.4).

Two of the samples (Beta 178269, from Juniper Lake and Beta 175776, from Harney Dune) yielded post modern carbon ages (PMC), indicating that the individuals represented by the samples expired sometime after 1950 and the radiocarbon dating results may be affected by atmospheric carbon. Additionally, two other samples yielded recent ages that overlap the historic period in Oregon. An age of 147-13 BP came from the Harney Lake sample (Beta 178270), and an age of 140-27 BP came from one of the Juniper Lake samples (Beta 174838). All accounts of the historic period in Oregon indicate that bison were locally extinct from the area by the 1800's (Bailey 1923, 1932).

Three hypotheses can be used to explain the modern aged samples obtained from the four samples mentioned above. First, the samples may have been misidentified, and actually represent Bos. Second, the samples may represent historic period Bison. This hypothesis is based on historic accounts of introduced bison in the late $19^{\text {th }}$ and early $20^{\text {th }}$ centuries (Park 1969). Finally, the radiocarbon dates themselves may be in error. To test these hypotheses, each modern aged sample should be reevaluated for proper identification. Likewise, references to bison ranching may help to eliminate the possibility that the specimens are domesticated or introduced bison. Finally, the potential of laboratory error can only be eliminated if pretreatment procedures are well documented. However, the bone sampled for dating may have degraded collagen, which can affect the 
outcome of the AMS dating process. Examination of the condition of the bone as well as referral to the ${ }^{13}$ value may reveal information about the bone which is indicative of error in the dating process.

The four samples with recent ages were re-evaluated to test the three hypotheses. The Harney Dune mandible fragment (Beta 175776) was re-evaluated, and determined to be misidentified. The bone is actually that of a cow (Bos), rather than a bison. The skull was collected from the surface of a known archaeological site in association with prehistoric artifacts, yet when referenced against identification manuals and comparative collections, the skull is undeniably that of a cow. The Harney Dune locale does remain a valid bison locale, however, because a bison skull was documented from the site and radiocarbon dating yielded an age of 250 BP (Mehringer personal communication 2003).

The misidentification of this specimen highlights the challenges with accepting the data of previous research without knowledge of the criteria used in identification. It also highlights the need for a comparative collection. In retrospect the bone should have been evaluated using a comparative collection prior to sampling it for radiocarbon dating, given the expense and time lost.

The Harney Lake sample (Beta 178270) was also re-evaluated and two possibilities exist to explain the modern date from this sample. First it should be stated that this bone (a skull) was compared to other bison skulls and examined using an identification manual; it is undeniably a bison. The first possibility for the recent age hinges on historic accounts of bison ranching in the vicinity of Harney 
Lake (Park 1969). It is possible that this represents an introduced or domesticated bison. The next possibility hinges on the condition of the specimen itself. The bone was assigned a weathering stage of 4 , indicating that the collagen had somewhat degraded. Though the AMS laboratory did not indicate that there was a problem with the sample, the $\quad{ }^{13}$ value of $-18.7 \%$ is not typical of $\quad{ }^{13}$ values from this region, which are nearer to $-20+/-2 \%$ (Chisolm et al. 1995; Gupta and Polach 1985), therefore a low amount of collagen or contamination of secondary carbon may have caused error in the dating process. Given the potential for error in the dating process, this specimen was removed from my final sample of dated bison bones.

Two samples from Juniper Lake yielded recent ages (Beta 1734838 and Beta 178269). Two possibilities exist for both of these samples. Both specimens were highly fragmented and assigned weathering stages of 4 . Though identified by a professional archaeologist, with expertise in faunal analysis, it is possible that these bones were misidentified. However, a third bone from the same provenience (AA 55520) yielded an age of 285-266 BP. A more likely explanation is apparent when we analyze the ${ }^{13}$ values for each sample. Both samples have ${ }^{13}$ values atypical of the region. When one sample (Beta 174838) was retested at another AMS lab, it yielded a different age and different $\quad{ }^{13}$ value. Because the second ${ }^{13}$ value was more typical of those from the region $(-20.2 \%)$, this date was accepted, and the previous date was rejected based on potential error in the dating process. 
A fifth sample deserving discussion is the Wildcat Canyon specimen (AA 55516). This specimen, tested at the University of Arizona AMS lab, yielded an age of 3368-2842 cal BP The ${ }^{13}$ value of $-9.5 \%$ is anomalous to this study, and extremely different from the average (by over $10 \%$ ) for a bone from this region. AMS lab personnel cautioned that this age is most likely in error, perhaps from secondary contamination with recent $\mathrm{C}^{4}$ grasses (Hodgins personal communication 2003). Interestingly, a previously obtained conventional $\mathrm{C}^{14}$ date from a bison bone collected from the same provenience at Wildcat Canyon yielded an age of 4301-2957 BP (Schroedl 1973). Schroedl mentioned that this sample is also likely to be in error due to low collagen values. It is interesting that two bones were sampled from the same provenience, and yielded similar ages, yet error in the dating process highlights potential problems with both ages.

Schroedl suggested that artifacts in association with the bison bones support the radiocarbon age determination. Because the stratigraphy of the site is well documented and radiocarbon ages as well as typological artifacts have been found in association with bison bones from four strata, I chose not to discard this locale. However, I will place more weight on the suggested ages of associated artifacts 2,000 BP (Schroedl 1973) than with the AMS bone dates.

The remainig 10 specimens provide an unambiguous chronology for bison in eastern Oregon. Paisley Caves yielded the oldest bison bone age (801-670 BP). This date is supported by the presence of time sensitive projectile points (Jenkins personal communication). Catlow Cave and Roaring Springs Caves yielded very 
similar ages, ranging between 554-424 BP. As mentioned earlier, prehistoric ages for bison at Juniper Lake were supported by an age of 285-266 BP. Another Juniper Lake sample (Beta 174839) yielded an age of 506-419 BP. The radiocarbon ages of bison from the Malheur Lake paleontological site support the age range of nearby archaeological sites. Three bison remains from the Malheur Lake paleontological site yielded ages ranging from 513-269 BP.

Overall, results from radiocarbon dating of previously undated contexts provide a clear pattern of bison habitation in the Basin and Range region of eastern Oregon. Bison remains from this region are aged between 801-166 BP. The seven hundred year time period represented by the Basin and Range samples tested for this study is supported by results from previously dated contexts in eastern Oregon (Lyons 2000; Mehringer personal communication 2003). 
Table 4.3 Conventional and calibrated ages of bison bone samples. All ages calibrated using CALIB 4.4 (Stuiver and Reimer 1993), which uses Stuiver et al 1998a, 1998b for $\mathrm{C}^{14}$ calibrations. Conventional ages ending in "pme" (percent modern carbon) indicate a modern age (sometime after 1950) and may be influenced by secondary atmospheric carbon. Highlighted ages represent questionable dates, see discussion in text.

\begin{tabular}{|c|c|c|c|c|c|c|}
\hline site name & $\begin{array}{l}\text { site } \\
\text { type }\end{array}$ & laboratory & catalog \# & $\begin{array}{c}\text { conventional } \\
\mathrm{C}^{14} \text { age }\end{array}$ & $\delta^{13} \mathrm{C} \%$ & $\begin{array}{c}\text { calibrated age } \\
\text { (2 sigma) }\end{array}$ \\
\hline \multirow{4}{*}{$\begin{array}{c}\text { Juniper Lake } \\
\text { 35HA22 }\end{array}$} & \multirow{4}{*}{ A } & Beta & 174838 & $50+/-40 \mathrm{BP}$ & $-18.4 \%$ & $140-21 \mathrm{BP}$ \\
\hline & & Arizona & AA 55520 & $149+/-45 \mathrm{BP}$ & $-20.2 \%$ & 285-166 BP \\
\hline & & Beta & 174839 & $370+/-40 \mathrm{BP}$ & $-20.2 \%$ & $506-419 \mathrm{BP}$ \\
\hline & & Beta & 178269 & $122.5+/-.05 \mathrm{pmc}$ & $-18.6 \%$ & 01919pizest \\
\hline \multirow{3}{*}{ Malheur Lake } & \multirow{3}{*}{$P$} & Beta & 174837 & $250+/ 40 \mathrm{BP}$ & $-20.0 \%$ & 333-269 BP \\
\hline & & Beta & 175777 & $400+1.40 \mathrm{BP}$ & $-20.2 \%$ & $518-424$ BP \\
\hline & & Beta & 175778 & $390+1-40 \mathrm{BP}$ & $-19.6 \%$ & $513-422 \mathrm{BP}$ \\
\hline Harney Lake & $P$ & Beta & 178270 & $100+/-40 \mathrm{BP}$ & $-18.7 \%$ & $147 \times 13 \mathrm{BI}$ \\
\hline $\begin{array}{c}\text { Harney Dune } \\
\text { 35HA718 }\end{array}$ & A & Beta & 175776 & $124.3+1-0-.6 \mathrm{p} \mathrm{pmc}$ & $-19.5 \%$ & 0 8P-present \\
\hline \multirow{2}{*}{$\begin{array}{c}\text { Roaring } \\
\text { Springs Cave } \\
\text { 35HA433 }\end{array}$} & \multirow[b]{2}{*}{ A } & Arizona & AA 55514 & $409+/-41 \mathrm{BP}$ & $-21.0 \%$ & $524-425$ BP \\
\hline & & Arizona & AA 55519 & $480+/-42 \mathrm{BP}$ & $-20.4 \%$ & $544-466 \mathrm{BP}$ \\
\hline \multirow{2}{*}{$\begin{array}{l}\text { Catlow Cave } \\
\text { 35HA405 }\end{array}$} & \multirow{2}{*}{ A } & Arizona & AA 55518 & $442+/-41 \mathrm{BP}$ & $-21.5 \%$ & $543-432 \mathrm{BP}$ \\
\hline & & Arizona & AA 55515 & $404+/-41 \mathrm{BP}$ & $-21.2 \%$ & $521-424 \mathrm{BP}$ \\
\hline $\begin{array}{c}\text { Paisley Cave } \\
34 \mathrm{LK} 3400\end{array}$ & A & Arizona & AA 55659 & $846+/-65$ BP & $-20.6 \%$ & $801-670 \mathrm{BP}$ \\
\hline $\begin{array}{l}\text { Wildcat } \\
\text { Canyon } \\
\text { 35GM9 }\end{array}$ & A & Arizona & AA 55516 & $2900+/=100 \mathrm{BP}$ & $-9.5 \%$ & $3268-2842131$ \\
\hline
\end{tabular}




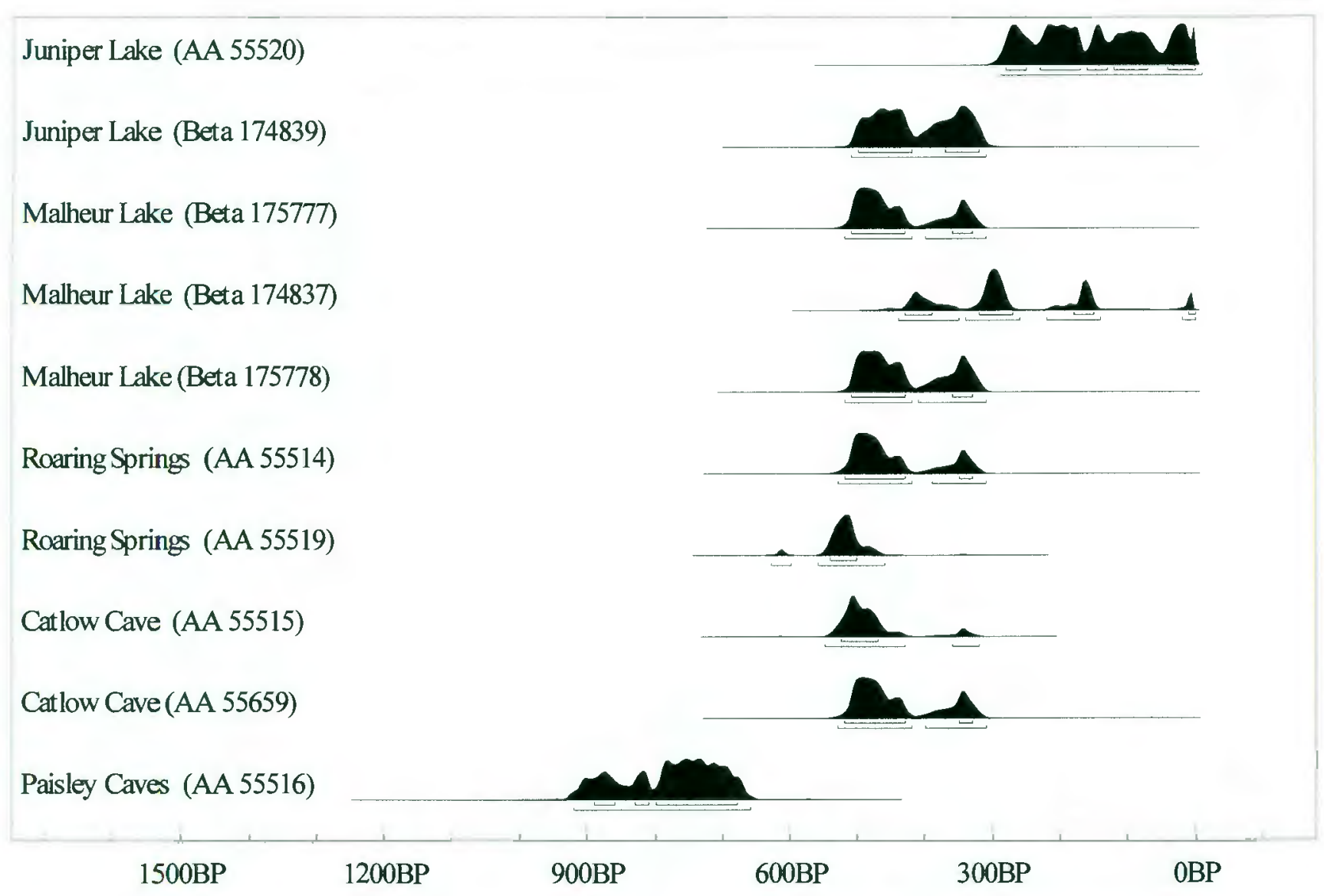

Figure 4.4 Calibrated BP ages of bison bone samples. Calibration curves created using OxCal 3.9 (Bronk 1995, 2001). Atmospheric data for calibrations supplied by CALIB 4.4 (Stuiver and Reimer 1993), which uses the following references for $\mathrm{C}^{14}$ calibrations: Stuiver et al 1998a, 1998 b. 


\section{Chapter 5 Discussion and Conclusion}

\section{Spatial Distribution of Bison in Eastern Oregon}

Most dated components containing bison are located in the Basin and Range physiographic region (Figure 5.1). Additionally, though most of the sites in the Basin and Range region contain deposits assigned to the 1,000-150 BP time period, all four time periods are represented in the region. In contrast, the Columbia Plateau is represented by four dated components from two localesall aged 3,000 1,000 BP. Finally, one locale, archaeological site 35UN80, dated between the $1,000-140$ BP time period was located in the Blue Mountains.

As mentioned earlier, our knowledge of the spatial distribution of bison may be affected by the intensity of archaeological investigations in certain areas and may not reflect their true prehistoric distribution. Differences in frequency of bison records across physiographic regions may also be explained by variation in landscape and habitat. Some regions in the Intermountain West may not have been appropriate for large herds of grazing mammals such as bison (Daubenmire 1985; Mack and Thompson 1982). In eastern Oregon, the Lava Plains region contains no record of bison. The volcanic and vegetative history of this region may account for the lack of bison (Franklin and Dyrness 1988). To test the appropriateness of the Lava Plains region for supporting bison, a similar study focusing on other grazing mammals such as deer, elk or pronghorn may be useful.

Elevation may be another parameter limiting bison habitat. Researchers have determined elevation limitations for certain plant and animal species (Brown 
1971; Franklin and Dyrness 1988). Likewise mountain ranges and deep valleys may have limited the movement of bison across the landscape. My data suggests that fewer bison were recorded in higher elevation regions such as the Blue Mountains and the Owyhee Uplands. To test elevation as a limiting factor of bison habitat or any other pattern of spatial distribution, a comparative analysis of other regions in the Intermountain West would be useful. For instance, if a similar study were undertaken in eastern Washington or Idaho, would bison be more numerous in physiographic regions sharing characteristics with the Columbia Plateau and Basin and Range in eastern Oregon?

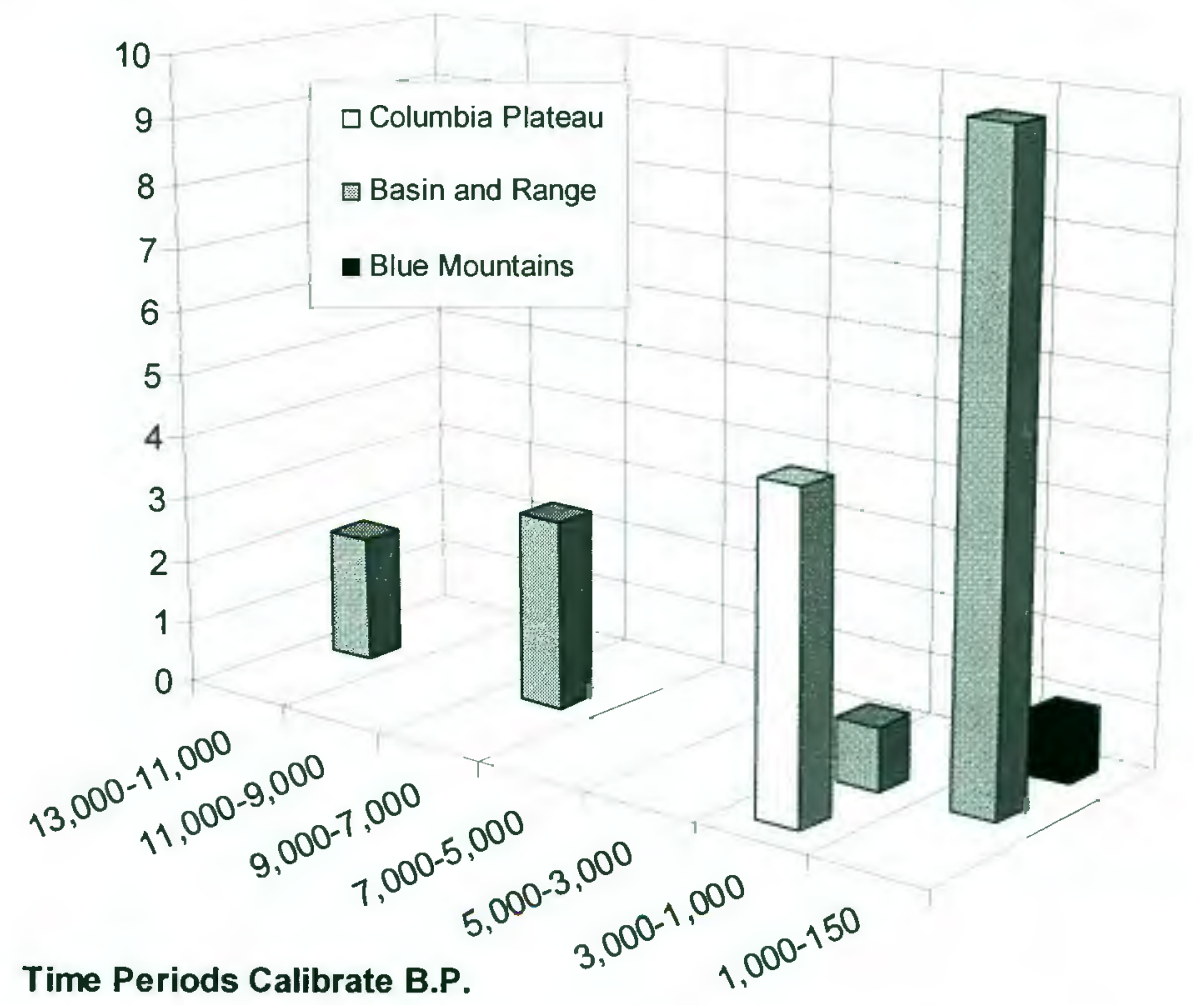

Figure 5.1 Number of dated components by eastern Oregon physiographic region. 


\section{Synthesis of Bison Chronology in Eastern Oregon}

Bison chronology from archival research and radiocarbon dating of previously undated contexts provides a clear temporal distribution of bison throughout the Holocene in eastern Oregon. Bison chronology for eastern Oregon can be divided into four distinct time periods (Table 5.1). Time periods are arbitrarily set at one, two, and four thousand year intervals and components are assigned to time periods using midpoints of the calibrated 2-sigma ranges (for locales with radiocarbon dates) and age ranges based on associated artifacts. Some sites have components spanning time periods; these were tallied once in both time periods.

Table 5.1 Dated components per time period for dated bison locales in eastern Oregon.

\begin{tabular}{|c|c|c|c|c|c|c|}
\hline & \multicolumn{6}{|c|}{ Time Period BP } \\
\hline Locale & $\begin{array}{l}1,000 \\
150\end{array}$ & $\begin{array}{l}3,000- \\
1,000\end{array}$ & $\begin{array}{l}7,000 \\
3,000\end{array}$ & $\begin{array}{l}9,000- \\
7,000\end{array}$ & $\begin{array}{l}11,000- \\
9,000\end{array}$ & $\begin{array}{l}13,000 \\
11,000\end{array}$ \\
\hline & \multicolumn{6}{|c|}{ /_Bison bison-___ Bison antiquus/occidentalis-- } \\
\hline $\begin{array}{l}\text { Wildcat } \\
\text { Canyon }\end{array}$ & & $\mathrm{X}$ & & & & \\
\hline 35UM1 & & $\mathrm{X}$ & & & & \\
\hline Connley & & & & $\mathrm{X}$ & & $\mathrm{X}$ \\
\hline $\begin{array}{l}\text { Caves } \\
\text { Skull Creek }\end{array}$ & & & & & & \\
\hline Dunes & $X$ & & & & & \\
\hline Lost Dune & $\mathrm{X}$ & & & & & \\
\hline Juniper Lake & $\mathrm{X}$ & & & & & \\
\hline Catlow Cave & $\mathrm{X}$ & & & & & \\
\hline $\begin{array}{l}\text { Roaring } \\
\text { Springs Cave }\end{array}$ & $\mathrm{X}$ & & & & & \\
\hline Paisley Caves & $\mathrm{X}$ & & & & & \\
\hline Malheur Lake & $\mathrm{X}$ & & & & & \\
\hline $\begin{array}{l}\text { Dirty Shame } \\
\text { Rockshelter }\end{array}$ & $\mathrm{X}$ & $\mathrm{X}$ & & $\mathrm{X}$ & & \\
\hline 35 UN80 & $\mathrm{X}$ & $\mathrm{X}$ & & & & \\
\hline
\end{tabular}




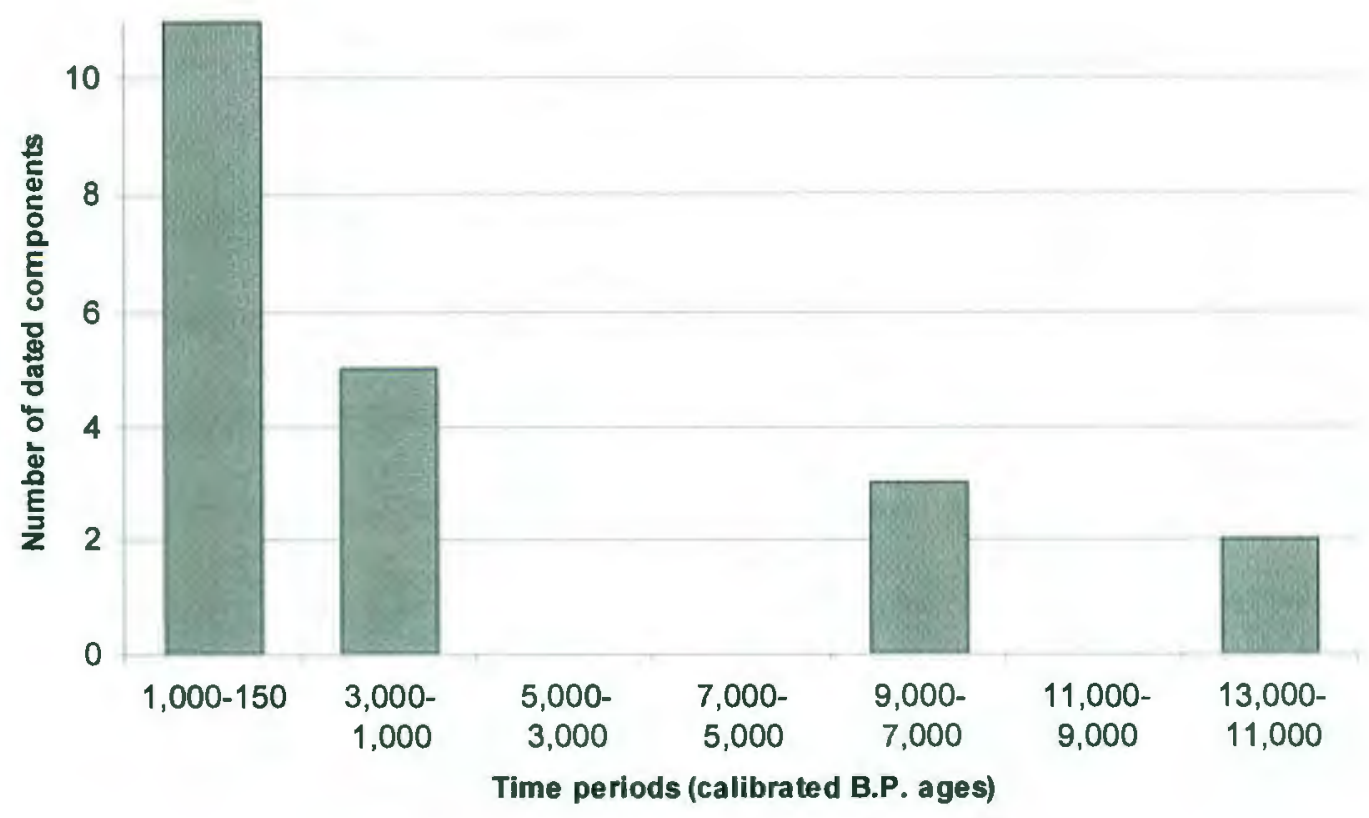

Figure 5.2 Number of dated components by time period.

The time period with the greatest number of dated components containing bison is $1,000-150 \mathrm{BP}$ (Figure 5.2). This time period is represented by nine bison locales in eastern Oregon. Though small sample sizes prevent detailed discussion of change in abundance over time, it is apparent from my data that extinct bison species (Bison antiquus and occidentalis) were scarce throughout the early Holocene, and disappeared by 7,000 BP. A 4,000 year gap in the middle Holocene is followed by the appearance of modern bison (Bison bison) after 3,000 BP. Bison increased in abundance throughout the late Holocene until becoming locally extinct sometime before $150 \mathrm{BP}$.

It is not apparent whether the 4,000 year gap in the middle Holocene represents the absence of bison altogether or the absence of datable components from this time period. Changes in human subsistence patterns during this time 
period may also account for fluctuations in faunal assemblage frequencies.

Previous researchers have correlated changes in human subsistence activity and mammalian abundance during the middle Holocene with fluctuations in climate (Bedwell 1973; Grayson 1977, 1993; Lyman 1985).

Bedwell (1973) noted a gap in human occupation at Connelly Caves between 7,000-4,000 BP. In the faunal assemblage he also noted a decline in waterfowl after 7,200 BP, and suggested the water level in nearby lakes and marshes had drastically receded during the middle Holocene due to low overall precipitation and higher temperatures. Recent research measuring fluctuations in plant pollens and mammalian fauna has supported Bedwell's hypothesis (Mehringer 1985; Wigand 1987). Mehringer (1985) recorded increasing sagebrush in proportion to grass at Fish Lake and Wildhorse Lake in southeast Oregon during the middle Holocene (7,000-4,000 BP), which indicates a period of less effective moisture.

Overall, there are fewer records of human occupation during the middle Holocene in much of eastern Oregon. Paleoenvironmental data suggests the environment during this time period was inhospitable to humans in the Basin and Range region of eastern Oregon (Aikens and Jenkins 1994). The effects of the middle Holocene climate conditions on bison populations is not as clearly understood; however, as my data from eastern Oregon suggests, bison were not present during this time period in great enough numbers to be represented in archaeofaunal or paleofaunal assemblages. 
According to Mehringer (1985), grasses began to return to eastern Oregon after $4,400 \mathrm{BP}$ and were most abundant after $2,400 \mathrm{BP}$. This change in climate correlates with the appearance of bison in the Columbia Plateau and Basin and Range of eastern Oregon around 2,000 B.P. (Aikens 1977; Schroedl 1973; Wegener 1998; this study).

The highest concentration of bison in eastern Oregon occurred between 600-300 BP (Figure 5.3). This pattern can also be correlated with fluctuations in temperature and effective moisture. Jones et al. (1999) wrote extensively on the Medieval Climatic Anomaly, which occurred between 1,150-600 BP. During this time, periods of drought severely affected human subsistence and population dynamics. Though little research for this time period has focused on faunal populations, it can be assumed that drought conditions affected all life during the suggested time period. An increase in bison abundance in eastern Oregon after 600 BP correlates with the end of the climatic anomaly. Increasing moisture and decreasing temperatures between 600 and $300 \mathrm{BP}$ (the Little Ice Age) possibly signify a return of good bison grazing habitat.

The disappearance of bison sometime between $300-150 \mathrm{BP}$ is more difficult to associate with climate changes. Fine scaled climate models for this time period are lacking. Climate models do however highlight fluctuations in climate in the late Holocene, which may have extended into the early historic period as well (Jones et al 1999; Mehringer 1996). Likewise, another factor limiting our understanding of the late prehistoric period in parts of eastern Oregon is the 
relatively few archaeological records available this time perod (Campbell1991). Further research on the late prehistoric period in eastern Oregon and the entire Intermountain West is needed to resolve issues of mammalian faunal abundance fluctuations. 


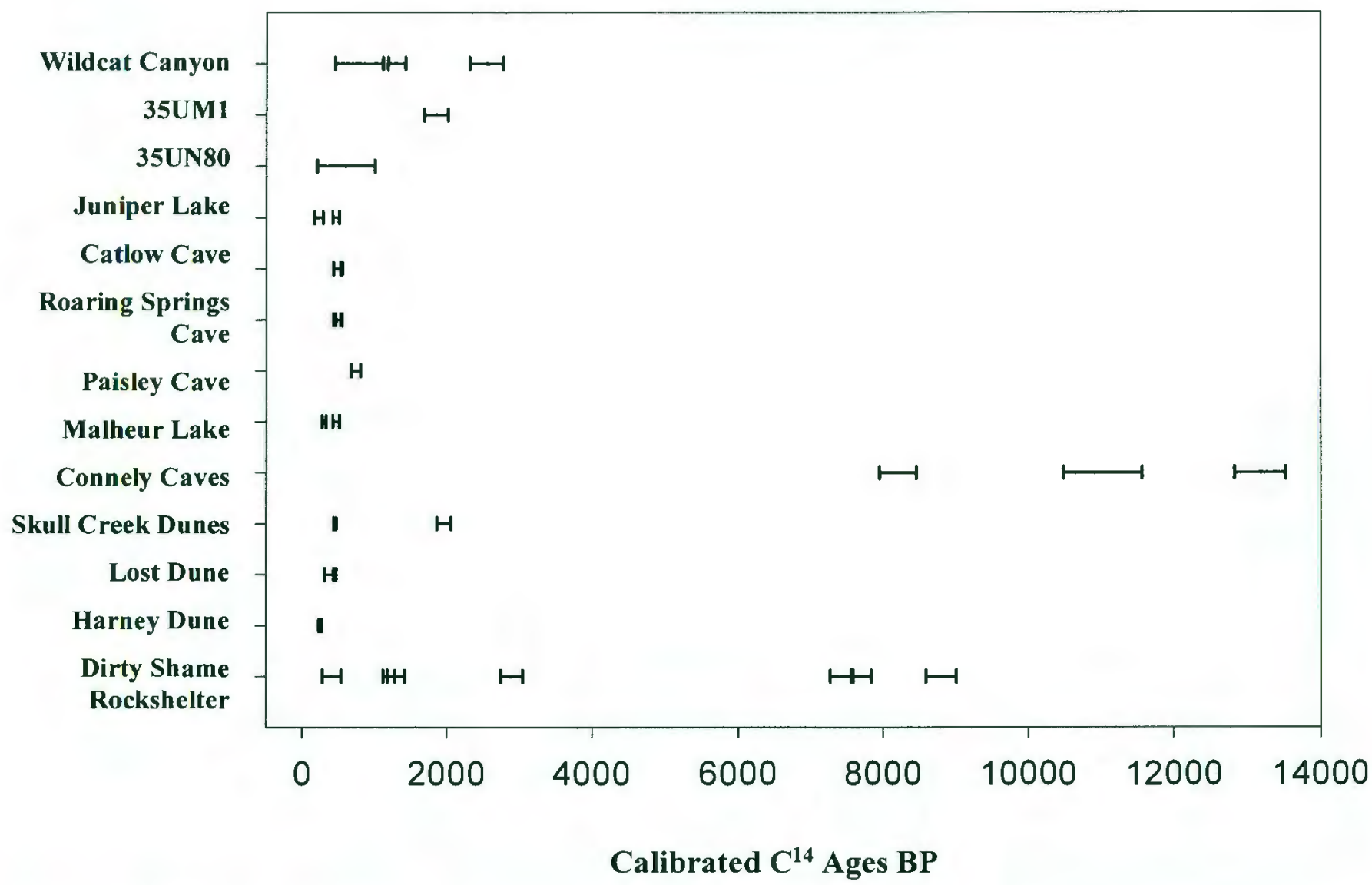

Figure 5.3 Radiocarbon dating results from archival research and previously undated contexts. Error bars represent 2 sigma calibrated BP midpoints and standard deviation. Some bars represent individual bone dates and others represent dated strata containing bison bone. Standard deviation for Skull Creek Dunes, Lost Dune and Harney Dune were unknown, therefore arbitrarily assigned a standard deviation of 50 for visual purposes. 
Bison in the Intermountain West

One goal of this study was to determine the temporal pattern of bison in eastern Oregon and compare it to other regions of the Intermountain West (Figure 4.6). Bison records from eastern Oregon support hypotheses from previous research in the Intermountain West suggesting that bison were most abundant during the late Holocene (Butler 1971; Chatters et al. 1995; Lyman 1985; Lupo and Schmitt 1997; Plew and Sundell 2000; Schroedl 1973) (Figure 5.3). The 4,000 year gap in bison records from eastern Oregon during the middle Holocene is somewhat anomalous to the Intermountain West. Bison records from eastern Washington (Lyman 1985) and the Snake River Plain in Idaho (Butler 1971; Plew and Sundell 2000) contain middle Holocene aged bison components, yet they are few in number compared to late Holocene records.

The pattern of late Holocene bison records throughout the Intermountain West is somewhat comparable. Butler (1971) suggested bison were most numerous in the Snake River Plain of Idaho between 3,400-2,900 BP and again between 700150 BP. Plew and Sundell's (2002) sample size was comparably larger than Butler's and they found that bison were most abundant between 2,000-150 BP. Lyman (1985) suggested that in eastern Washington bison were most numerous from 2,000-500 BP. Records from eastern Oregon support an abundance of bison between 2,000-150 BP.

A closer look at the late Holocene in eastern Oregon reveals that bison were most numerous between $600-300 \mathrm{BP}$. This pattern is in contrast to the pattern 
suggested by Lupo and Schmitt (1997) for the Great Salt Lake area, and the Columbia Plateau pattern suggested by Schroedl (1973). Both authors suggest that bison were in decline during the late prehistoric period. For Lupo and Schmitt (1997) this decline began after 650 BP, and for Schroedl (1973) the decline began after $1,500 \mathrm{BP}$.

Early Holocene records from the entire Intermountain West are scarce. There are only two sites in eastern Oregon with ages ranging from $11,000-7,000$ BP, three in eastern Washington (Daugherty 1956; Schroedl 1973), and seven in the Snake River Plain of Idaho (Butler 1971; Plew and Sundell 2000). If the number of archaeological sites can be taken as an indication of the relative numbers of bison present in the paleoenvironment, then it can be stated that bison were relatively scarce in the Intermountain West during the early and middle Holocene and abundant during the late Holocene. To evaluate fine scaled fluctuations in abundance, larger sample sizes are needed as well as methods for aggregating records so that intra-regional comparisons can be made.

A second goal was to evaluate eastern Oregon bison abundance and determine if the records can be used to address debates over bison abundance in the Intermountain West. Though bison records from eastern Oregon are not appropriate for evaluating fine scaled fluctuations in abundance over time, they can be used to evaluate the overall pattern of bison abundance in the Intermountain West throughout the Holocene. There are two different ways to evaluate the abundance of bison from archaeological and paleontological contexts. We can 
evaluate either the number of locales with bison remains, or examine the percentage of the total faunal assemblage represented by bison.

Two sites from eastern Oregon provide enough data to evaluate bison abundance using the second method. A quick review of these sites may be helpful for understanding relative bison abundance. Of the 3,461 mammalian skeletal elements recovered from Dirty Shame, 156 (4.5\%) were identified as bison. At Skull Creek Dunes bison represent $0.4 \%$ of the total fauna. Using the percentage of bison per total faunal or total mammalian faunal assemblages as a measure of abundance, it is clear that bison at Skull Creek Dunes and Dirty Shame Rockshelter were scarce. Likewise, of all the sites in eastern Oregon reviewed during this study, only three contain five or more bison NISP. Comparisons need to be made between these data and data from sites in other regions of the Intermountain West to understand the broader pattern of bison abundance west of the Continental Divide.

Evaluating bison abundance by the first method gives similar results. Only 19 locales in eastern Oregon contained bison remains. In comparison to other regions of the Intermountain West, Oregon has relatively fewer bison records. Bison have been recovered from over 47 sites in eastern Washington (Chatters et al. 1995; Lyman 1985; Morgan 1993); however, few of these sites contain enough identifiable bison remains to determine the minimum number of individuals (Morgan1993). Over 32 archaeological sites in the Snake River Plain of Idaho contain bison remains but only six have five or more NISP (Butler 1971; Plew and 
Sundell 2000). Even though regions outside eastern Oregon have a greater number of recorded bison locales, the number of bison remains recovered at these sites is small.

The overall abundance of bison in the Intermountain West is relatively small when compared to the large bison hunting components discovered in the Plains Region. Likewise the relationship between humans and bison in the Intermountain West is not as obvious as in the Plains. Prey ranking scales used in optimal foraging theory place bison high in terms of value to prehistoric humans (Henrikson 2002). When and where bison were available to prehistoric humans they would have been procured (Lupo and Schmitt 1997). The relative scarcity of bison in archaeofaunal assemblages in the Intermountain West suggests that they were not available in numbers great enough to be a significant part of the prehistoric human subsistence pattern.

\section{Implications for Modern Wildlife Management}

One final research goal was to determine if bison records from eastern Oregon provide data relevant to modern management issues and conservation biology. Results of this study suggest that bison were never abundant in eastern Oregon. The reasons for this lack of abundance remain unanswered. However, as demonstrated by several researchers, eastern Oregon forage, climate, and landscape may not have been appropriate for large herds of bison (Mack and Thompson 1982; Van Vuren 1987). 
East of the Continental Divide, modern cattle grazing is analogous to prehistoric bison grazing, in terms of grassland ecology (Mack and Thompson 1982). However, in the Intermountain West, the introduction of cattle resulted in invasion by Eurasian weeds. This reaction to the introduction of large herds of cattle suggests that plant communities in the Intermountain West did not co-evolve with large numbers of grazing mammals (Mack and Thompson 1982).

The introduction of cattle to the Intermountain West began after explorers and fur trappers described the setting to settlers anxious to increase their land base west of the Continental Divide. The Intermountain West was seen as a vast open land void of natural grazers to compete for resources (Young and Sparks 2002). The abundance of forage to support the horses of these early visitors to the Intermountain West as well as knowledge from Native Americans that bison once roamed the area led them to believe the region was appropriate for cattle grazing. The degradation of the grasslands of the Intermountain West caused by the introduction of cattle challenges the assumption that the land is appropriate for large mammal grazing. Likewise, the presence of bison in archaeological and paleontological faunal assemblages in the Intermountain West by no means supports arguments for current grazing activities.

Paleofaunal research has suggested that ungulate populations in the entire Intermountain West have always been small compared to those of the Plains (Kay 1994). Bison records from eastern Oregon support this hypothesis. Bison in Intermountain West reserves such as Yellowstone National Park are currently 
managed at population levels denser than they were in the paleoenvironment. Bison, elk and other ungulates in Yellowstone are in danger of extinction due to diseases and lack of forage exacerbated by overpopulation. Similarly, overgrazing of public and private lands has resulted in the almost complete destruction of native grasslands. To prevent this, future work in wildlife management and conservation biology should include paleofaunal and paleoenvironmental records.

\section{Summary}

My study has provided insight into the temporal and spatial distribution of bison in eastern Oregon throughout the Holocene. Radiocarbon dates from previously undated contexts, as well as a thorough literature review highlights similarities between eastern Oregon bison records and those from other regions of the Intermountain West.

Researchers have questioned whether the presence of bison in eastern Oregon archaeofaunal assemblages represent local herds, strays wandering into the area, or bison products brought into the region by hunters returning from logistical hunting trips east of the Continental Divide. The discovery of a large bone bed with the skeletal remains of over 30 individual bison in Malheur Lake in southeast Oregon(Bailey 1923; Elliot 1909) proves bison were living locally and died of natural causes independent of human hunting activity. Three radiocarbon dates from this previously undated locale suggest these bison were living here between 269-513 BP. Radiocarbon dates from archaeological sites in eastern Oregon 
support the hypothesis that bison were living in eastern Oregon during the late prehistoric period.

I obtained radiocarbon dates for three previously undated archaeological sites and one paleontological site. These data are extremely valuable for establishing not only the chronology of bison in the region, but also evaluating the antiquity of the archaeological sites themselves. Two of the sites in my study, Roaring Springs Cave and Catlow Cave, are among the earliest professionally excavated sites in Oregon (Cressman et al. 1940; Cressman 1942). The faunal assemblages of these sites have not been fully documented and radiocarbon dates were not available before this study. My research adds valuable information to our understanding of the chronology at these sites and the overall chronology and abundance of bison in eastern Oregon. Further research will expand this study beyond eastern Oregon to provide the Holocene spatial and temporal distribution of bison throughout the entire Intermountain West. 


\section{References}

Agenbroad, L. D.

1968 The Five Fingers Buffalo Jump. Explorers Journal 46

(4):279-286.

1978 Buffalo Jump Complexes in Owyhee County, Idaho. Plains Anthropologist 23(82):213-221.

Aikens, C. M.

1993 Archaeology of Oregon. U.S. Department of the Interior, Bureau of Land Management, Portland.

Aikens, C. M. and R. Greenspan

1988 Ancient Lakeside Culture in the Northern Great Basin: Malheur Lake, Oregon. Journal of California and Great Basin Anthropology 10:3261.

Aikens, C. M. and D. L. Jenkins

1994 Environment, Climate, Subsistence, and Settlement: 11,000 Years of Change in the Fort Rock Basin, Oregon. In Archaeological Researches in the Northern Great Basin: Fort Rock Archaeology Since Cressman, edited by C. M. Aikens and D. L. Jenkins. University of Oregon Anthropological Papers No. 50, Eugene.

Aikens, M. C., D. L. Cole and R. Stuckenrath

1977 Excavations at Dirty Shame Rockshelter Southeastern Oregon.

Tebiwa 4.

Ames, K. M.

2002 Review of the Archaeological Data in the Kennewick Man Cultural Affiliation Report. www.cr.nps.gov/aad/kenewick/ames $3 \mathrm{htm}$.

Ames, K. M., D. E. Dumond, J. R. Galm and R. Minor 1998 Prehistory of the Southern Plateau. In Columbia Plateau, edited by D. E. Walker Jr. Handbook of North American Indians. vol. 12, W. C. Sturtevant, general editor. Smithsonian Institution, Washington, D.C.

Anastasio, A.

1972 The Southern Plateau: An Ecological Analysis of Intergroup Relations. Northwest Anthropological Research Notes 6(2):109-229. 
Bailey, V.

1923 Buffalo in Oregon. Journal of Mammalogy 4:254-55.

1932 Buffalo of the Malheur Valley, Oregon. Proceedings of the Biological Society of Washington 45:47-48.

1936 The Mammals and Life Zones of Oregon. North American Fauna 55. U.S. Department of Agriculture, Bureau of Biological Survey, Washington D.C.

Balkwill, D. M. and S. L. Cumbaa

1992 A Guide to the Identification of Postcranial Bones of Bos taurus and Bison bison. Syllogeus 71. Canadian Museum of Nature, Ottawa.

Bamforth, D. B.

1988 Ecology and Human Organization on the Great Plains. Plenum Press, New York.

Barnard, C. and O. H. Frankel

1964 Grass, grazing animals, and man in historic perspective. In Grasses and Grasslands, edited by C. Barnard, pp. 1-12. Macmillan, New York.

Bayham, F. E.

1979 Factors Influencing the Archaic Pattern of Animal Utilization. The Kiva 44(3):219-235.

Bedwell, S. F.

1969 Prehistory and Environment of the Pluvial Fort Rock Lake Area of

South Central Oregon. Dissertation, University of Oregon.

1973 Fort Rock Basin Prehistory and Environment. University of Oregon, Eugene.

Behrensmeyer, A. K.

1978 Taphonomic and Ecological Information from Bone Weathering. Paleobiology 4(2):150-162.

Binns, A.

1967 Peter Skene Ogden: Fur Trader. Binfords and Mort, Portland. 
Bronk, R. C.

1995 Radiocarbon Calibration and Analysis of Stratigraphy. The OxCal Program. Radiocarbon 37(2):425-430.

2001 Development of the Radiocarbon Program OxCal. Radiocarbon 43 (2A):355-363.

Brown, A. G. and C. Caseldine

1999 Biodiversity from Paleoecological Data. Journal of Biogeography $26(1): 3-5$.

Brown, J. H.

1971 Mammals on Mountaintops: Nonequilibrium Insular Biogeography. The American Naturalist 105(945):467-477.

Burroughs, R. D.

1961 The Natural History of the Lewis and Clark Expedition. Michigan State University Press.

Butler, R. B.

1971 The Origin of the Upper Snake Country Buffalo. Tebiwa 14 (2):1-20.

1978 Bison Hunting in the Desert West Before 1800: The PaleoEcological Potential and the Archaeological Reality. Plains Anthropologist 23 (82):106-1 12.

Caldwell, W. W. and O. L. Mallory

1967 Hells Canyon Archaeology. Publications in Salvage Archaeology, Smithsonian Institution River Basin Surveys, No. 6.

Campbell, S. K.

1991 A Critical Review of Protohistoric Research in the Columbia Plateau. Archaeology in Washington 3:41-65.

Cannon, K. P.

2001 What the Past can Provide: Contribution of Prehistoric Bison Studies to Modern Bison Management. Great Plains Research1:145 -74.

Chatters, J. C., S. K. Campbell, G. D. Smith and P. E. M. Jr. 1995 Bison Procurement in the Far West: A 2,100-Year-Old Kill Site on the Columbia Plateau. American Antiquity 60(4):751-763. 
Chisholm, B. and S. D. Jonathan Driver, and Henry P. Schwartz 1995 Assessment of Prehistoric Bison Foraging and Movement Patterns Via Stable-Carbon Isotopic Analysis. Plains Anthropologist 31:193-205.

Christman, G. M.

1971 The Mountain Bison. American West 8(3):44-47.

Cole, D. L.

1968 Report on Archaeological Research in the John Day Dam Reservoir Area-1967. Report submitted to the National Park Service.

Connolly, $\mathrm{T}$.

1999 Newberry Crater: A Ten-Thousand Year Record of Human

Occupation and Environmental Change in the Basin-Plateau Borderlands.

University of Utah Anthropological Papers, No. 121.

Connolly, T. J., D. L. Jenkins and J. Benjamin 1993 Archaeology of Mitchell Cave (35WH122). A Late Period Hunting Camp in the Ochoco Mountains, Wheeler County Oregon. University of Oregon Anthropological Papers, No. 46, Eugene.

Cowles, J.

1960 Cougar Mountain Caves. Privately published, Rainier.

Cressman, L. S.

1936 Archaeological Survey of the Guano Valley Region in Southeastern Oregon. University of Oregon.

1942 Archaeological Researches in the Northern Great Basin. Carnegie Institution of Washington, Washington D.C.

1986 Prehistory of the Northern Area. In Great Basin, edited by W. L. D'Azevedo. Handbook of North American Indians. vol. 11, W. C.

Sturtevant, general editor. Smithsonian Institution, Washington, D.C.

Cressman, L. S., H. Williams and A. D. Krieger

1940 Early Man in Oregon; Archaeological Studies in the Northern Great Basin., Eugene.

Dalquest, W. W.

1948 Mammals of Washington. University of Kansas Museum of Natural History, Publication 2, Lawrence. 
Danz, H. P.

1995 Of Bison and Man. University Press of Colorado, Denver.

Daubenmire, R.

1985 The Western Limits of The Range of the American Bison. Ecology $66(2): 622-624$.

Daugherty, R. D.

1956 Archaeology of the Lind Coulee Site, Washington. Proceedings of the American Philosophical Society 100(3):223-278.

Dean, E.

1993 Faunal Remains from Structure 3 at the Big M Site, Fort Rock

Basin, Oregon. In Archaeological Researches in the Northern Great Basin:

Fort Rock Archaeology Since Cressman, edited by C. M. A. a. D. L.

Jenkins. University of Oregon Anthropological Papers, No. 50, Eugene.

Dincauze, D. F.

2000 Environmental Archaeology, Principles and Practice. Cambridge

University Press, Cambridge, UK.

Draper, J. A.

1989 Archaeology of Chokecherry Cave, 35 GR500 Grant County,

Oregon. Center for Northwest Anthropology, Report No. 9. Washington

State University.

Driver, J. C.

1992 Identification, Classification, and Zooarchaeology. Circaea 9

(1):35-47.

Dugas, D. P. and M. Bullock

1994 Headquarters Site: An Archaeological and Stratigraphic

Assessment of 35HA403. U.S. Fish and Wildlife Service Cultural Resource Series, No.10.

Dumond, D. E. and R. Minor

1983 Archaeology in the John Day Reservoir, The Wildcat Canyon Site 35GM9. University of Oregon Anthropological Papers, No. 30, Eugene.

Elliott, T. C.

1909 The Peter Skene Ogden Journals. The Quarterly of the Oregon Historical Society 10(4). 
1910 The Peter Skene Ogden Journals 1825-1826. The Quarterly of the Oregon Historical Society 11(1):229-278.

Foster, D. R.

2000 From Bobolinks to Bears: Interjecting Geographical History into Ecological Studies, Environmental Interpretation, and Conservation Biology. Journal of Biogeography 27:27-30.

Franklin, J. F. and C. T. Dyrness 1988 Natural Vegetation of Oregon and Washington. Oregon State University Press, Corvallis.

Frison, G. C. and C. A. Reher 1970 Age Determination of Buffalo by Teeth Eruption and Wear. Plains Anthropologist 15(50).

Galbraith, W. A. and W. E. Anderson

1971 Grazing History of the Northwest. Journal of Range Management $24(1): 6-12$.

Gifford, D. P.

1981 Taphonomy and Paleoecology: A Critical Review of Archaeology's Sister Disciplines In Advances in Archaeological Method and Theory, edited by M. B. Schiffer. Vol. 4. Academic Press, New York.

Gillespie, R., R. E. M. Hedges and J. O. Wand 1984 Radiocarbon Dating of Bone by Accelerator Mass Spectrometry. Journal of Archaeological Science 11:165-170.

Grayson, D. K.

1977 Paleoclimatic Implications of the Dirty Shame Rockshelter Mammalian Fauna. Tebiwa 9.

1981 A Critical View of the use of Archaeological Vertebrates in Paleoenvironmental Reconstruction. Journal of Ethnobiology 1(1):28-38.

1984 Quantitative Zooarchaeology. Academic Press, New York.

1987 The Biogeographic History of Small Mammals in the Great Basin: Observations on the last 20,000 Years. Journal of Mammalogy 68(2):359375.

1993 The Desert's Past: A Natural Prehistory of the Great Basin. Smithsonian Institution Press, Washington, D.C. 
Greene, H. W.

2002 Forward. In American Bison, by Dale F. Lott. University of California Press, Berkeley.

Gupta, S. K. and H. A. Polach

1985 Radiocarbon Dating Practices at ANU. Research School of Pacific Studies, ANU.

Guthrie, R. D.

1970 Bison Evolution and Zoogeography in North America During the Pleistocene. The Quarterly Review of Biology 45(1):1-15.

Haines, F.

1938 The Northward Spread of Horses Among the Plains Indians.

American Anthropologist 40:429-437.

1938 Where did the Plains Indians get their Horses? American Anthropologist 40:112-117.

1967 Western Limits of the Buffalo Range. American West 4(4).

Henrikson, S. L.

2002 Ponds, Rivers and Bison Freezers: Evaluating a Behavioral Ecological Model of Hunter-Gatherer Mobility on Idaho's Snake River Plain. Ph. D. Dissertation, University of Oregon, Eugene.

Isenburg, $\mathbf{A}$.

2000 Destruction of the Bison. Cambridge University Press, Cambridge.

Jackman, E. R. and R. A. Long

1964 The Oregon Desert. Caxton Printers, Ltd., Caldwell.

Jenkins, D. J. and C. M. Aikens

1994 Paulina Marsh Archaeological Survey. In Archaeological

Researches in the Northern Great Basin: Fort Rock Archaeology Since Cressman, edited by C. M. Aikens and D. L. Jenkins. University of Oregon Anthropological Papers, No. 50, Eugene.

Jenkins, D. L.

1994a Archaeological Excavations at Paquet Gulch Bridge Site: A Pithouse Village in the Deschutes River Basin, Southwest Columbia Plateau, OR. University of Oregon Anthropological Papers, No. 49, Eugene. 
1994b Archaeological Investigations at Three Wetlands Sites in the Silver Lake Area of the Fort Rock Basin. In Archaeological Researches in the Northern Great Basin: Fort Rock Archaeology Since Cressman, edited by C. M. Aikens and D. L. Jenkins. University of Oregon Anthropological Papers, No. 50, Eugene.

1994c Archaeological Survey and Excavations in the Duncan Creek Research Area: Changing Human Use of Uplands Environments West of Silver Lake. In Archaeological Researches in the Northern Great Basin: Fort Rock Archaeology Since Cressman, edited by C. M. Aikens and D. L. Jenkins. University of Oregon Anthropological Papers, No. 50, Eugene.

1994d Excavations at Four Habitation Sites in the Boulder Village Uplands: A Preliminary Report. In Archaeological Researches in the Northern Great Basin: Fort Rock Archaeology Since Cressman, edited by C. M. A. a. D. L. Jenkins. University of Oregon Anthropological Papers, No. 50, Eugene.

Johnson, C. W.

1951 Protein as a Factor in the Distribution of the American Bison. Geographical Review 41:330-331.

Jones, T. L. and L. M. R. Gary M. Brown, Janet L. McKivar, W. Geoffrey Spaulding, Douglas J. Kennett, Andrew York, and Phillip L. Walker 1999 Environmental Imperatives Reconsidered; Demographic Crises in Western North America During the Medieval Climatic Anomaly. Current Anthropology 40(2):137-170.

Kay, C. E.

1994 Aboriginal Overkill: The Role of Native Americans in Structuring Western Ecosystems. Human Nature 5(4):359-398.

Kingston, C. S.

1932 Buffalo in the Pacific Northwest. Washington Historical Quarterly 23.

Koch, P. L., A. K. Behrensmeyer, A. W. Stott, R. P. Evershed, N. Tuross and M. L. Fogel

2000 The Effects of Weathering on the Stable Isotope Composition of Bone. Ancient Biomolecules 3(2). 
Laliberte, A. S. and W. Ripple

2003 Wildlife Encounters by Lewis and Clark: A Spatial Analysis of Interactions Between Native Americans and Wildlife. Bioscience 53(10): 994-1003.

Livingston, S. D.

2000 The Relevance of Ethnographic, Archaeological, and

Paleontological Records to Models for Conservation Biology. In Models for the Millennium: Great Basin Anthropology Today, edited by C. Beck. University of Utah Press, Salt Lake City.

Lott, D. F.

2002 American Bison. Uniषrsity of California Press, Berkeley.

Lupo, K. D. and D. N. Schmitt

1997 On Late Holocene Variability in Bison Populations in the Northeastern Great Basin. Journal of California and Great Basin Anthropology 19(1):50-69.

Lyman, R. L.

1982 Archaeofaunas and Subsistence Studies. Advances in Archaeological Method and Theory 5:331-393.

1985a Bone Frequencies: Differential Transport, In Situ Destruction, and the MGUI. Journal of Archaeological Science 12:221-236.

1985b Paleozology of the Avey's Orchard Site. In Avey's Orchard: Archaeological Investigations of a Late Prehistoric Columbia River Community, edited by J. R. Galm and R. A. Masten. Eastern Washington University Reports in Archaeology and History, No. 100-42, Cheney.

1991 Late Quaternary Biogeography of the Pygmy Rabbit (Brachylagus idahoensis) in Eastern Washington. Journal of Mammalogy 72(1):110-117.

1995 Determining when Rare (Zoo-)Archaeological Phenomena are Truly Absent. Journal of Archaeological Method and Theory 2(4):369-423.

1996 Applied Zooarchaeology: The Relevance of Faunal Analysis to Wildlife Management. World Archaeology 28(1):110-125.

1998 White Goats White Lies. University of Utah Press, Salt Lake City. 
Lyman, R. L. and S. Livingston

1983 Late Quaternary Mammalian Zoogeography of Eastern Washington. Quaternary Research 20:360-373.

Lyman, R. L. and S. Wolverton 2002 The Late Prehistoric-Early Historic Game Sink in the Northwestern United States. Conservation Biology 16(1):73-85.

Lyons, W. H.

2000 Where the Lost was Found: Geologic Sources of Artifact Raw Materials from Lost Dune (25HA792), Harney County, Southeastern Oregon. Dissertation, Washington State University.

Mack, R. N. and J. N. Thompson 1982 Evolution in Steppe with Few Large Hoofed Mammals. The American Naturalist 119(6):757-773.

Martin, P. S. and C. R. Szuter 1999 War Zones and Game Sinks in Lewis and Clark's West. Conservation Biology 13(1):36-45.

McDonald, J. N. 1981 North American Bison, their Classification and Evolution. University of California Press, Berkeley, CA.

Mehringer, P. J.

1985 Late-Quaternary Pollen Records from the Interior Pacific Northwest and Northern Great Basin of the United States. In Pollen Records of LateQuaternary North American Sediments, edited by V. M. Bryant and R. G. Holloway. American Association of Stratigraphic Palynologists, Dallas.

1996 Columbia River Basin Ecosystems: Late Quaternary Environments. Interior Columbia Basin Ecosystem Management Project. Washington State University, Departments of Anthropology and Geology.

Mehringer, P. J. a. P. E. W.

1988 Comparison of Late Holocene Environments from Woodrat Middens and Pollen: Diamond Craters, Oregon. In Packrat Middens: The Last 40,000 Years of Biotic Change, edited by J. L. Betancourt, T. L. V. Devender and P. S. Martin. University of Arizona Press, Tuscon, AZ. 
Morgan, V.

1993 Cultural Resource Investigations at 45AD104, an Upland Bison

Site, Adams County, Washington. Eastern Washington University Reports in Archaeology and History 100-81. Eastern Washington University.

Moulton, G. E. (editor)

1986-1996 The Journals of the Lewis and Clark Expedition, by M. Lewis and W. Clark. 2-10. University of Nebraska Press, Lincoln.

Oetting, A. C.

1994 Early Holocene Rabbit Drives and Prehistoric Land Use Patterns on Buffalo Flat, Christmas Lake Valley, Oregon. In Archaeological Researches in the Northern Great Basin: Fort Rock Basin Archaeology Since Cressman, edited by C. M. Aikens and D. L. Jenkins. University of Oregon Anthropological Papers, No. 50, Eugene.

Olsen, S. J.

1960 Post-Cranial Skeletal Characteristics of Bison and Bos. Peabody Museum of Archaeology and Ethnography, Harvard.

Osborne, D.

1953 Archaeological Occurrences of Pronghorn Antelope, Bison and Horse in the Columbia Plateau. Scientific Monthly 77(5):260-269.

Park, E.

1969 The World of the Bison. J.B. Lipincott Company, Philadelphia.

Pettigrew, R. M.

1985 Archaeological Investigations on the East Shore of Lake Abert, Lake County, Oregon. University of Oregon Anthropological Papers 32.

University of Oregon, Eugene.

Plew, M. G. and T. Sundell

2000 The Archaeological Occurrence of Bison on the Snake River Plain. North American Archaeologist 21(2):119-137.

Raymond, A. W.

1994 The Surface Archaeology of Harney Dune (35HA718), Malheur National Wildlife Refuge, Oregon. U.S. Department of the Interior, Fish and Wildlife Service, Region 1. Cultural Resource Series, No. 9. 
Reher, C. A.

1978 Buffalo Population and Other Deterministic Factors in a Model of Adaptive Process on the Short-grass Plains. Plains Anthropologist 23(82):23-39.

Reher, C. A. and G. C. Frison 1980 The Vore Site, 48CK392, A Stratified Buffalo Jump in the Wyoming Black Hills. Plains Anthropologist Memoir 16.

Riddell, F. A.

1952 The Recent Occurrence of Bison in Northeastern California. American Antiquity 18:168-169.

Sampson, C. G.

1985 Nightfire Island: Later Holocene Lakemarsh Adaptation on the Western Edge of the Great Basin. University of Oregon Anthropological Papers, No. 33, Eugene.

Schalk, R. F. editor

1980 Cultural Resource Investigations for the Second Powerhouse Project at McNary Dam, Near Umatilla, Oregon. Washington State University, Laboratory of Archaeology and History, No. 1.

1983 Cultural Resource Investigations for the Lyons Ferry Fish Hatchery Project, Near Lyons Ferry, Washington. Washington State University Laboratory of Archaeology and History.

Schroedl, G. F. 1973 The Archaeological Occurrence of Bison in the Southern Plateau; Report of Investigations, No. 51. Laboratory of Anthropology, Washington State University.

Shaw, J. H. and M. Lee 1997 Relative Abundance of Bison, Elk, and Pronghorn on the Southern Plains. Plains Anthropologist 42(159):163-172.

Steward, J. H.

1936 Basin-Plateau Aboriginal Sociopolitical Groups Bulletin 120. Smithsonian Institution Bureau of Ethnology, Washington D.C.

Stuiver, M., and Reimer, P. J.

1993 Extended $\mathrm{C}^{14}$ Database and Revised CALIB Radiocarbon Calibration Program. Radiocarbon 35:215-230. 
Stuiver, M., P.J. Reimer, E. Bard, J.W. Beck, G.S. Burr, K.A. Hughen, B. Kromer, G. McCormac, J. van der Plicht and M. Spurk

1998 INTCAL98 Radiocarbon Age Calibration, 24000-0cal BP. Radiocarbon 40(3):1041-1083.

Stuiver, M., P. J. Reimer and T. F. Braziunas 1998 High Precision Radiocarbon Age Calibration for Terrestrial and Marine Samples. Radiocarbon 40(3):1127-1151.

The Oregonian

1928 Skull and Bones of Bison are Discovered Near Prineville. August 19.

The Oregonian

1930 The Buffalo of Malheur. December 27.

The Oregonian

1930 Buffalo Skulls Found. December 29.

The Oregonian

1931 Bison Bones Link in Chain Tying Dim age to Present. January 4.

The Oregonian

1931 [untitled article about bison in Oregon]. March 28.

The Oregon Journal

1931 Buffalo Bones Found in Lake Malheur Bed. July 27.

Thomas, S.

2001 Site Report for Juniper Lake (35HA22). On file at the Oregon State Office of Historic Preservation.

Thomas, S., J. Loring and A. Goheen

1983 An Aboriginal Pottery Site in Southeastern Oregon. In Contributions to the Archaeology of Oregon 1981-1982. Association of Oregon Archaeologists Occasional Papers, No 2.

Thompson, R. S. and J. I. Mead

1982 Late Quaternary Environments and Biogeography in the Great Basin. Quaternary Research 17:39-55. 
Tieszen, L. L.

1994 Stable Isotopes on the Plains: Vegetation Analyses and Diet Determinations. In Skeletal Biology in the Great Plains, Migration, Warfare, Health, and Subsistence, edited by D. W. Owsley and R. Jantz. Smithsonian Institution Press, Washington D.C.

Van Vuren, D.

1987 Bison West of the Rocky Mountains: An Alternative Explanation. Northwest Science 61(2):65-69.

1993 Evidence of Bison bison in the Great Basin. Great Basin Naturalist 53 (3):318-319.

Van Vuren, D. and M. P. Bray

1985 The Recent Geographic Distribution of Bison in Oregon. Murrelet 66:56-58.

von den Driesch, A.

1976 A Guide to the Measurement of Animal Bones from Archaeological Sites. Peabody Museum Bulletin 1. Peabody Museum of Archaeology and Ethnology, Harvard University.

Wegener, R. M.

1998 Late Holocene Stone Technology and Seed and Faunal Remains from Skull Creek Dunes Locality-6, Catlow Valley, Southeastern Oregon. Masters Thesis, Washington State University.

Wigand, P. E.

1987 Diamond Pond, Hamey County, Oregon: Vegetation History and Water table in the Eastern Oregon Desert. Great Basin Naturalist 47(3):427-457.

Wilde, J. D., R. Dalan, S. Wilke, R. Keuler and J. Foss

1983 Cultural Resource Survey and Evaluations of Select Parcels in the John Day Reservoir, Oregon. A Report Submitted to the U.S. Army Corps of Engineers. Geo-Recon International, Seattle.

1985 Prehistoric Settlements in the Northern Great Basin: Excavations and Collections Analysis in the Steens Mountain Area, Southeastern Oregon. Ph.D. Dissertation, Department of Anthropology, University of Oregon, Eugene. 
Wilson, $\mathrm{M}$.

1978 Archaeological Kill Site Populations and the Holocene Evolution of the Genus Bison. Plains Anthropologist 23(82):9-22.

Wilson, M. and L. B. Davis

1978 Epilogue: Retrospect and Prospect in the Man-Bison Paradigm.

Plains Anthropologist 23(82):312-335.

Wingard, G. F. 2001 Carlon Village, Land, Water, Subsistence, and Sedentism in the Northern Great Basin. University of Oregon Anthropological Papers, No. 57, Eugene.

Young, J. A. and B. A. Sparks

1985 Cattle in the Cold Desert. University of Nevada Press, Reno. 


\section{Appendix A}

Archaeological and Paleontological bison elements from eastern Oregon locales 
Appendix A Archaeological and Paleontological bison elements from eastern Oregon locales.

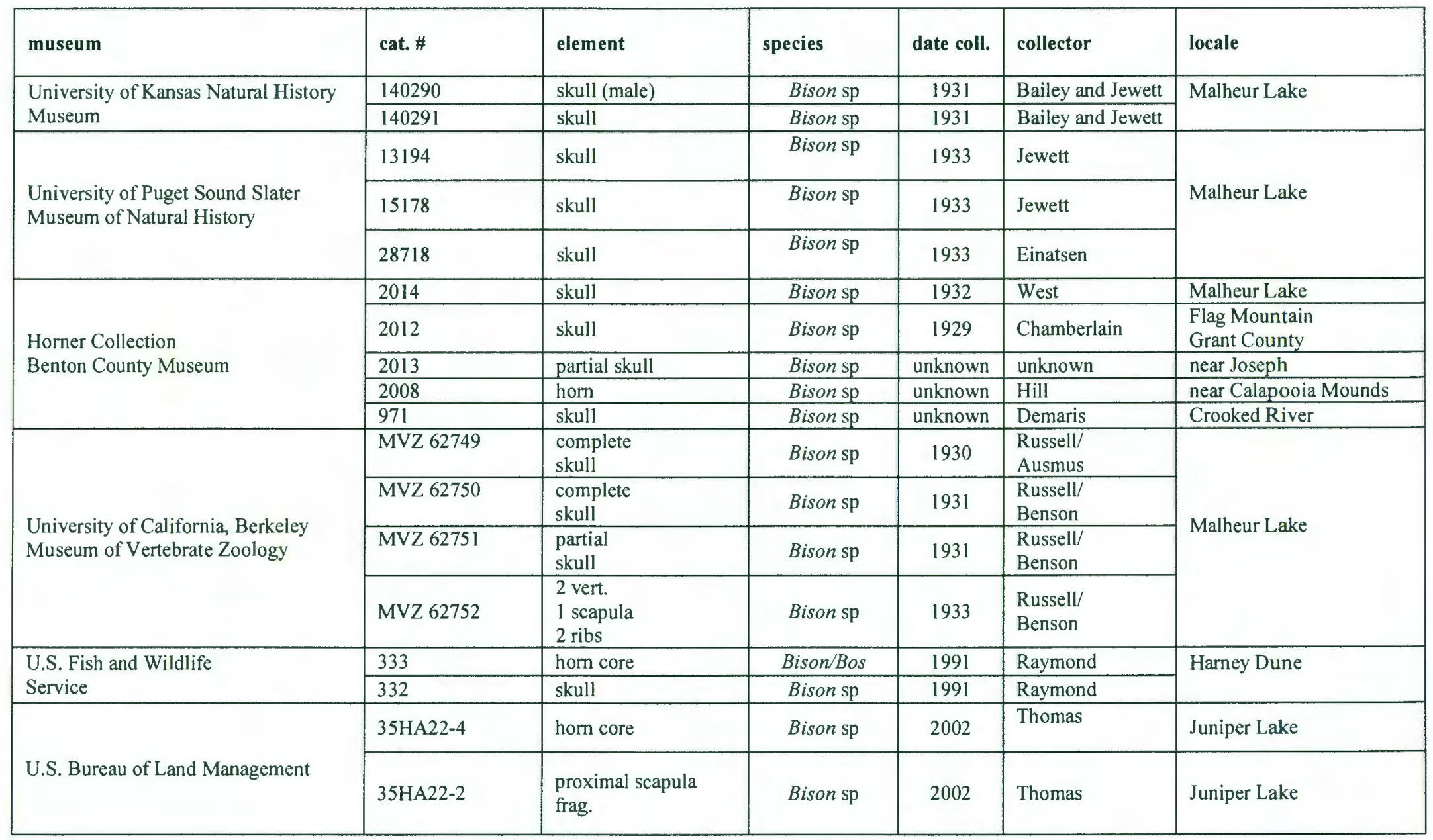

$\ddot{\theta}$ 


\begin{tabular}{|c|c|c|c|c|c|c|}
\hline museum & cat. \# & element & species & date coll. & collector & locale \\
\hline & 35HA22-3 & $\begin{array}{l}\text { distal femur } \\
\text { frag. }\end{array}$ & Bison $\mathrm{sp}$ & 2002 & Thomas & Juniper Lake \\
\hline & 35HA22-1 & $\begin{array}{l}\text { distal femur } \\
\text { frag. }\end{array}$ & Bison sp & 2002 & Thompson & Juniper Lake \\
\hline \multirow{16}{*}{ 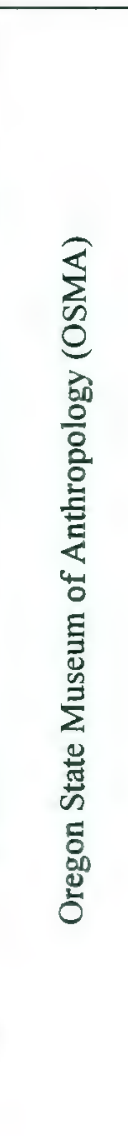 } & GM9/5 07-6/4 & tibia frag. & Bison sp. & unknown & unknown & Wildcat Canyon \\
\hline & GM9/5 07-5/4 & phalan $x$ & Bison sp. & unknown & unknown & Wildcat Canyon \\
\hline & GM9/5 P6-3/4a & femur frag. & Bison Bos & unknown & unknown & Wildcat Canyon \\
\hline & GM9/2 Y/8-2/2 & tooth frag. & Bison/Bos & unknown & unknown & Wildcat Canyon \\
\hline & GM9/2 AA23-1/2 & tooth frag. & Bison/Bos & unknown & unknown & Wildcat Canyon \\
\hline & GM9/2 BB24-3/2 & tooth frag. & Bison/Bos & unknown & unknown & Wildcat Canyon \\
\hline & GM9/2 AA23-5/2a & tooth frag. & Bison/Bos & unknown & unknown & Wildcat Canyon \\
\hline & GM $9 / 2$ AA23-2/2a & tooth frag. & Bison/Bos & unknown & unknown & Wildcat Canyon \\
\hline & GM9/2 Z24-1/2 & tooth frag. & Bison/Bos & unknown & unknown & Wildcat Canyon \\
\hline & GM $9 / 2$ BB25-9/2 & tooth frag. & Bison/Bos & unknown & unknown & Wildcat Canyon \\
\hline & GM9/2 BB25-9/2a & tooth frag. & Bison/Bos & unknown & unknown & Wildcat Canyon \\
\hline & $\mathrm{GM} 9 / 2 \mathrm{Y} / 18-3 / 3$ & tooth frag. & Bison/Bos & unknown & unknown & Wildcat Canyon \\
\hline & GM9/2 Z/8-4/3 & scapula frag. & Bison sp. & unknown & unknown & Wildcat Canyon \\
\hline & GM9/2 Y/9-3,4,5/2 & tibia frag. & Bison/Bos & unknown & unknown & Wildcat Canyon \\
\hline & GM9/2 X/8-3/3 & phalan $x$ & Bison/Bos & unknown & unknown & Wildcat Canyon \\
\hline & GM9/2 Z/9-5/3 & radius frag. & Bison/Bos & unknown & unknown & Wildcat Canyon \\
\hline
\end{tabular}




\begin{tabular}{|c|c|c|c|c|c|c|}
\hline museum & cat. \# & element & species & date coll. & collector & locale \\
\hline \multirow{5}{*}{ OSMA } & GM9/2 X/9-4/3a & phalanx frag. & Bison/Bos & unknown & unknown & Wildcat Canyon \\
\hline & GM9/6 & femur (juvenile) & Bison/Bos & unknown & unknown & Wildcat Canyon \\
\hline & GM9/6-M2P-2 & vert. frag. & Bison/Bos & unknown & unknown & Wildcat Canyon \\
\hline & GM9/5 M2P-1 & tibia frag. & Bison/Bos & unknown & unknown & Wildcat Canyon \\
\hline & GM9/5-X4 & metacarpal & Bison/Bos & unknown & unknown & Wildcat Canyon \\
\hline \multirow{4}{*}{ OSMA } & 35GM88 491-2-341 & phalanx & Bison sp. & unknown & unknown & 35GM88 \\
\hline & 35GM88 491-2-342 & phalanx & Bison sp. & unknown & unknown & 35GM88 \\
\hline & 35GM88 491-3-43 & phalanx & Bison sp. & unknown & unknown & 35GM91 \\
\hline & 35GM88 491-3-55 & phalanx & Bison sp. & unknown & unknown & $35 \mathrm{GM} 88$ \\
\hline \multirow{5}{*}{ OSMA } & A-15 20-2576 & phalanx & Bison sp. & unknown & unknown & 35GM88 \\
\hline & A-123 20-935 & phalan $x$ & Bison sp. & unknown & unknown & 35GM91 \\
\hline & A-16 20-263 & phalanx & Bison sp. & unknown & unknown & 35GM91 \\
\hline & A-14 20-959 & metatarsus & Bison/Bos & unknown & unknown & Catlow Cave \\
\hline & A-66 20-2577 & scapula frag. & Bison/Bos & unknown & unknown & Catlow Cave \\
\hline \multirow{3}{*}{ OSMA } & RS-3848 20-1123 & proximal scapula frag. & Bison sp. & unknown & unknown & Roaring Springs Cave \\
\hline & RS-3849 20-1124 & proximal scapula frag. & Bison sp. & unknown & unknown & Roaring Springs Cave \\
\hline & RS-3847 20-1122 & proximal radius frag. & Bison sp. & unknown & unknown & Roaring Springs Cave \\
\hline
\end{tabular}




\begin{tabular}{|c|c|c|c|c|c|c|}
\hline museum & cat. \# & element & species & date coll. & collector & locale \\
\hline OSMA & RS-3856 20-1131 & scapula frag. & Bison/Bos & unknown & unknown & Roaring Springs Cave \\
\hline OSMA. & FR-383 20-1219 & scapula (juvenile) & Bison/Bos & unknown & unknown & Fort Rock Cave \\
\hline $\begin{array}{l}\text { Idaho Museum } \\
\text { of Natural } \\
\text { History }\end{array}$ & IMNH & skull (male) & Bison sp. & unknown & unknown & Owyhee County \\
\hline \multirow{15}{*}{ 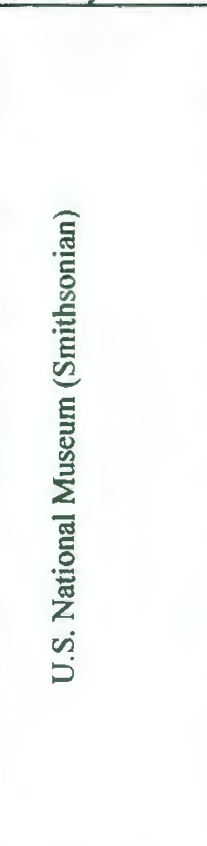 } & 246529 & skull & Bison sp. & 1925 & unknown & near Izee Grant Co. \\
\hline & 249841 & skull & Bison sp. & 1930 & unknown & Harney County \\
\hline & 249842 & skull & Bison sp. & 1930 & unknown & Malheur Lake \\
\hline & 249843 & skull & Bison sp. & 1930 & unknown & Malheur Lake \\
\hline & 249844 & skull & Bison sp. & 1930 & unknown & Malheur Lake \\
\hline & 249845 & skull & Bison sp. & 1930 & unknown & Malheur Lake \\
\hline & 249846 & skull & Bison sp. & 1930 & unknown & Malheur Lake \\
\hline & 249847 & skull & Bison sp. & 1930 & unknown & Malheur Lake \\
\hline & 249848 & skull & Bison sp. & 1930 & unknown & Malheur Lake \\
\hline & 249849 & skull & Bison sp. & 1930 & unknown & Malheur Lake \\
\hline & 249850 & skull & Bison sp. & 1930 & unknown & Malheur Lake \\
\hline & 249894 & skull & Bison sp. & 1931 & unknown & Malheur Lake \\
\hline & 249895 & skull & Bison sp. & 1931 & unknown & Malheur Lake \\
\hline & 250091 & skull & Bison sp. & 1931 & unknown & Malheur Lake \\
\hline & 250093 & skull & Bison sp. & 1931 & unknown & Malheur Lake \\
\hline
\end{tabular}

$\bar{\sigma}$ 


\begin{tabular}{|c|c|c|c|c|c|c|}
\hline museum & cat. \# & element & species & date coll. & collector & locale \\
\hline & 250094 & skull & Bison sp. & 1931 & unknown & Malheur Lake \\
\hline \multirow{4}{*}{$\begin{array}{l}\text { U.S. National } \\
\text { Museum }\end{array}$} & 250089 & skull & Bison sp. & 1931 & unknown & Malheur Lake \\
\hline & 250092 & skull & Bison sp. & 1931 & unknown & Malheur Lake \\
\hline & 250090 & skull & Bison sp. & 1931 & unknown & Malheur Lake \\
\hline & 250095 & skull & Bison sp. & 1931 & unknown & Malheur Lake \\
\hline $\begin{array}{l}\text { Denver Museum of } \\
\text { Natural History }\end{array}$ & 9786 & dentary & Bison sp & unknown & Benson & Malheur Lake \\
\hline
\end{tabular}

$\Xi$ 


\section{Appendix B}

Measurements of postcranial bison elements from archaeological sites in eastern Oregon. Measurements are defined in von den Driesch (1976) 
Appendix B Measurements of postcranial bison elements from archaeological sites in eastern Oregon. Measurements are defined in von den Driesch (1976). See Appendix C for illustrations of measurements.

\begin{tabular}{|c|c|c|c|}
\hline catalog number & element & measurement & value (centimeters) \\
\hline 35HA22-3 & distal end of femur fragment & $\mathrm{Bd}$ & 12.0 \\
\hline \multirow{3}{*}{ 25HA22-2 } & \multirow{3}{*}{ proximal scapula fragment } & $\mathrm{BG}$ & 5.0 \\
\hline & & $\mathrm{LG}$ & 6.0 \\
\hline & & GLP & 7.2 \\
\hline \multirow{2}{*}{ GM9/5 07-6/4 } & \multirow{2}{*}{ distal tibia fragment } & Dd & 4.8 \\
\hline & & $\mathrm{Bd}$ & 6.0 \\
\hline \multirow{3}{*}{ GM9/5 07-5/4 } & \multirow{3}{*}{$2^{\text {nd }}$ phalanx } & $\mathrm{Bp}$ & 3.4 \\
\hline & & $\mathrm{SD}$ & 3.2 \\
\hline & & Bd & 3.4 \\
\hline \multirow{3}{*}{$\mathrm{GM} 9 / 2 \mathrm{Z} / 8-4 / 3$} & \multirow{3}{*}{ proximal right scapula fragment } & $\mathrm{Bg}$ & 5.0 \\
\hline & & $\mathrm{LG}$ & 6.3 \\
\hline & & GLP & 7.7 \\
\hline \multirow{3}{*}{ GM9/5 X4 } & \multirow{3}{*}{ complete left metacarpal } & $\mathrm{Dp}$ & 3.5 \\
\hline & & $\mathrm{Bp}$ & 6.0 \\
\hline & & $\mathrm{GL}$ & 19.5 \\
\hline \multirow{5}{*}{ GM9/5 M2P-1 } & \multirow{5}{*}{ complete left tibia } & $\mathrm{Bp}$ & 11.1 \\
\hline & & $\mathrm{Bd}$ & 7.0 \\
\hline & & $\mathrm{Cd}$ & 5.2 \\
\hline & & Dd & 4.4 \\
\hline & & $\mathrm{GL}$ & (approx.) 14.2 \\
\hline \multirow{4}{*}{ A-15 20-2576 } & \multirow{4}{*}{ metatarsus } & $\mathrm{Bd}$ & 6.2 \\
\hline & & $\mathrm{Bp}$ & 4.9 \\
\hline & & $\mathrm{GL}$ & 23.5 \\
\hline & & $\mathrm{SD}$ & 3.4 \\
\hline \multirow{3}{*}{ A-123 20-935 } & \multirow{3}{*}{ scapula fragment } & $\mathrm{BG}$ & 4.8 \\
\hline & & LG & 6.5 \\
\hline & & GLP & 7.2 \\
\hline \multirow{3}{*}{$A-1620-263$} & \multirow{3}{*}{$1^{\text {st }}$ phalanx } & $\mathrm{GL}$ & 6.1 \\
\hline & & Dp & 3.1 \\
\hline & & & \\
\hline
\end{tabular}




\begin{tabular}{|c|c|c|c|}
\hline catalog number & element & measurement & value (centimeters) \\
\hline \multirow{2}{*}{ A-14 20-959 } & \multirow{2}{*}{$1^{\text {st }}$ phalanx } & $\mathrm{GL}$ & 5.8 \\
\hline & & $\mathrm{Dp}$ & 3.1 \\
\hline \multirow{2}{*}{ RS-3848 20-1123 } & \multirow{2}{*}{ proximal scapula fragment } & $\mathrm{BG}$ & 4.7 \\
\hline & & LG & 6.1 \\
\hline \multirow{2}{*}{ RS-3849 20-1124 } & \multirow{2}{*}{ proximal scapula fragment } & $\overline{B G}$ & 4.7 \\
\hline & & LG & 6.5 \\
\hline \multirow{4}{*}{ FR-383 20-1219 } & \multirow{4}{*}{ complete scapula (immature) } & $\mathrm{BG}$ & 4.9 \\
\hline & & $\mathrm{LG}$ & 5.4 \\
\hline & & GLP & 7.0 \\
\hline & & $\mathrm{Ld}$ & 16.5 \\
\hline
\end{tabular}




\section{Appendix C}

Illustrations of post-cranial mammalian measurements (adapted from von den Driesch 1976) 
Appendix C Illustrations of post-cranial mammalian measurements (adapted from von den Driesch 1976).

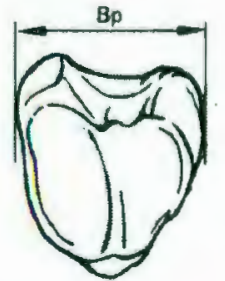

Figure 46c: Bos Phalanx 2, proximal view.
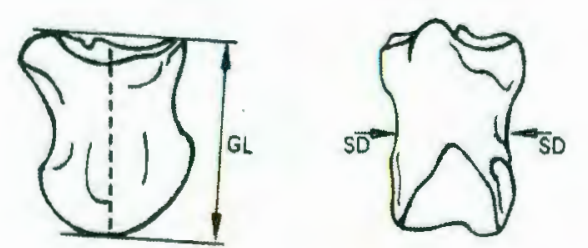

\section{Figure 46d: Bo}

Phalanx 2,

peripheral view.

Figure 46e: Bos

Phalanx 2,

dorsal view.



Figure 46f: Bos

Phalanx 2, volax/plantar vlew.

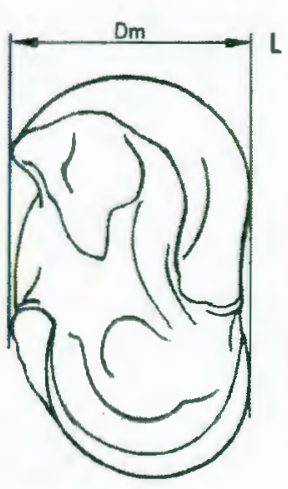

Figure 41c: Bos astragalus, medial view.

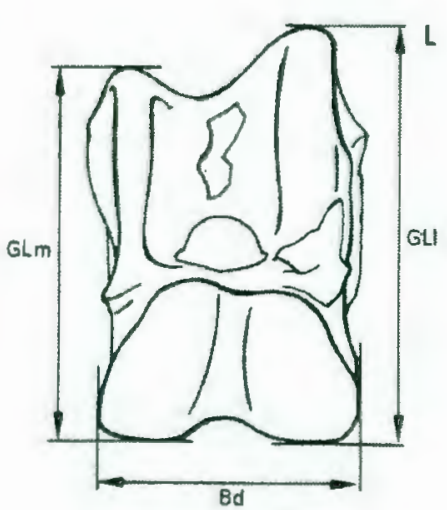

Figure 41d:

Bos astragalus, dorsal view.

Astragalus measurements

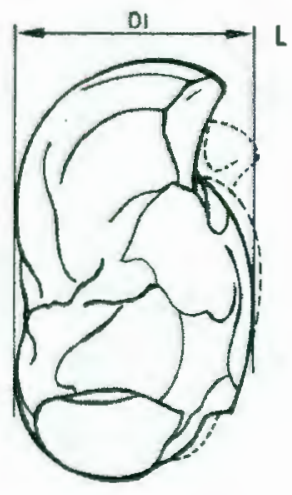

F1gure 41e: Bos astragalus, lateral view. 


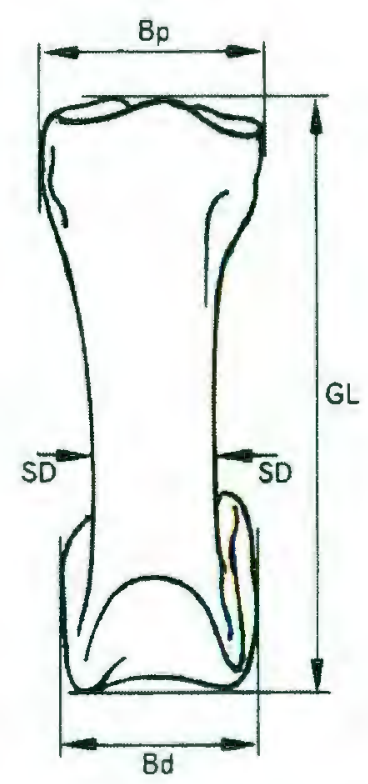

Figure 45c: Camelus Phalanx 1, dorsal view.

$1^{\text {st }}$ Phalanx measurements

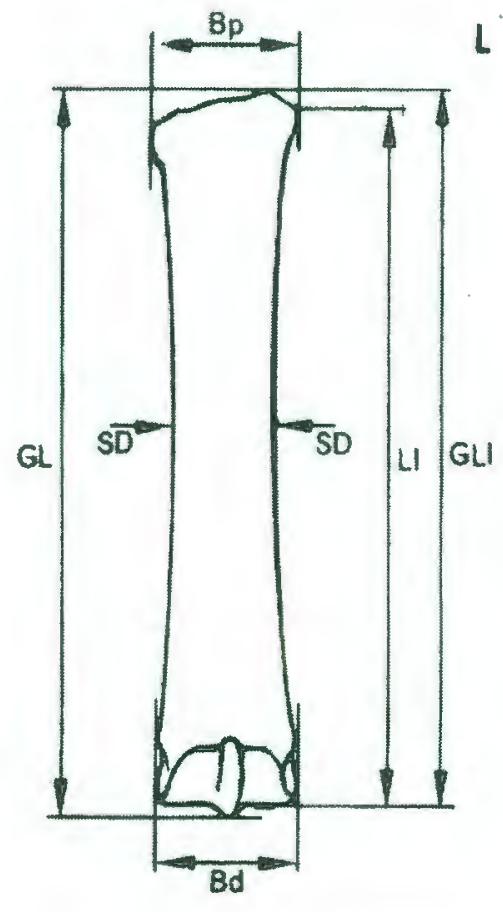

Figure 44a:, Equus Metacarpus III, dorsal view.

Metacarpus measurements

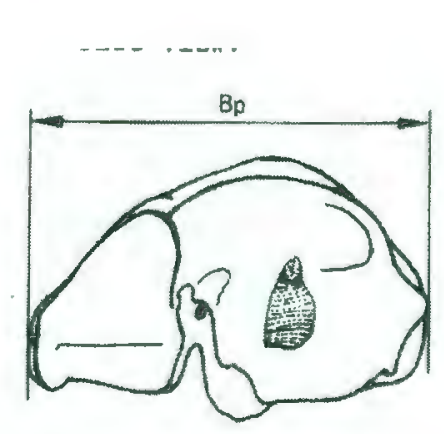

Figure 44f: Bos Metacarpus III ITIV proximal view.
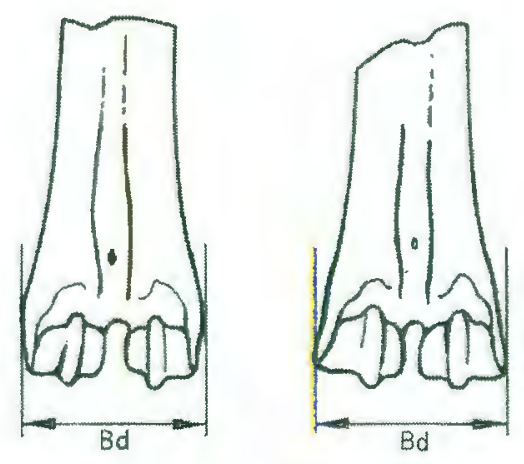

Figure 44h: Bos Metatarsi III+IV, dorsal view. 


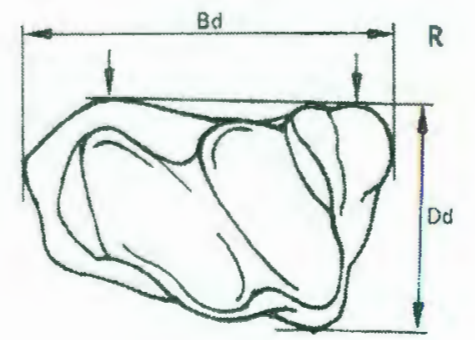

Figure 37c:

Equus tibia,

distal view.

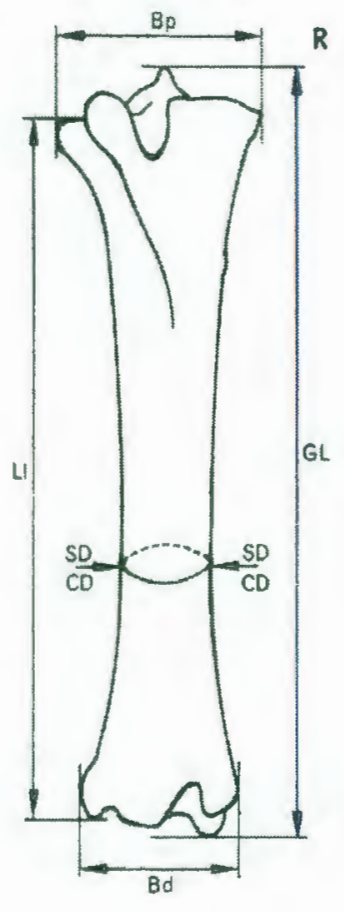

Figure 37a:

Equus tibia, dorsal view.

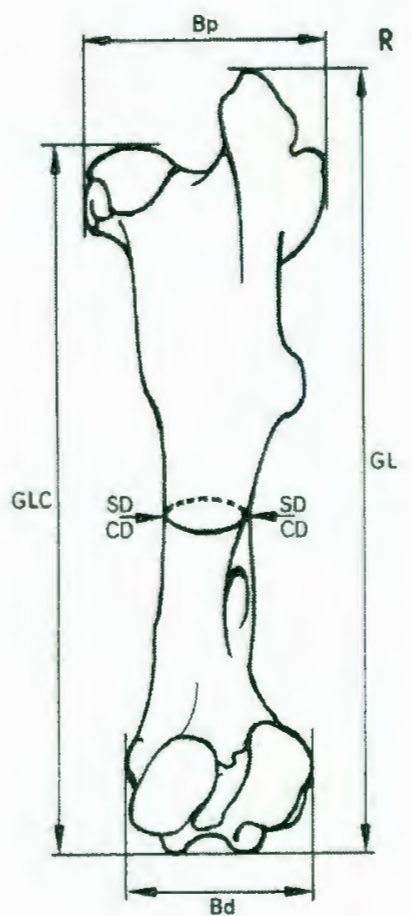

Figure 35a: Equus femur, caudal view.

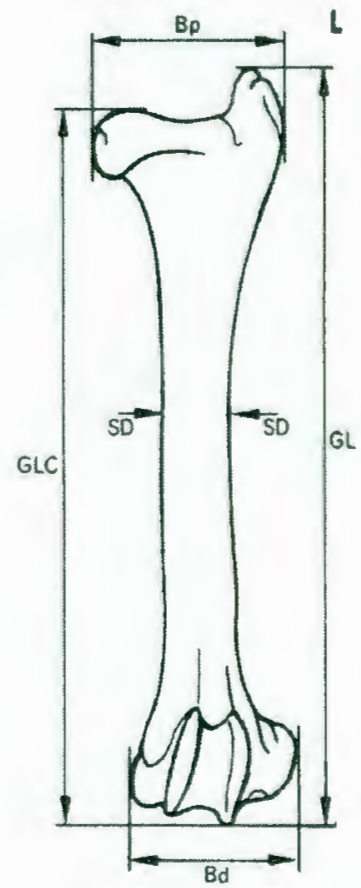

Figure 35b: Ovis femur, cranjal view. 


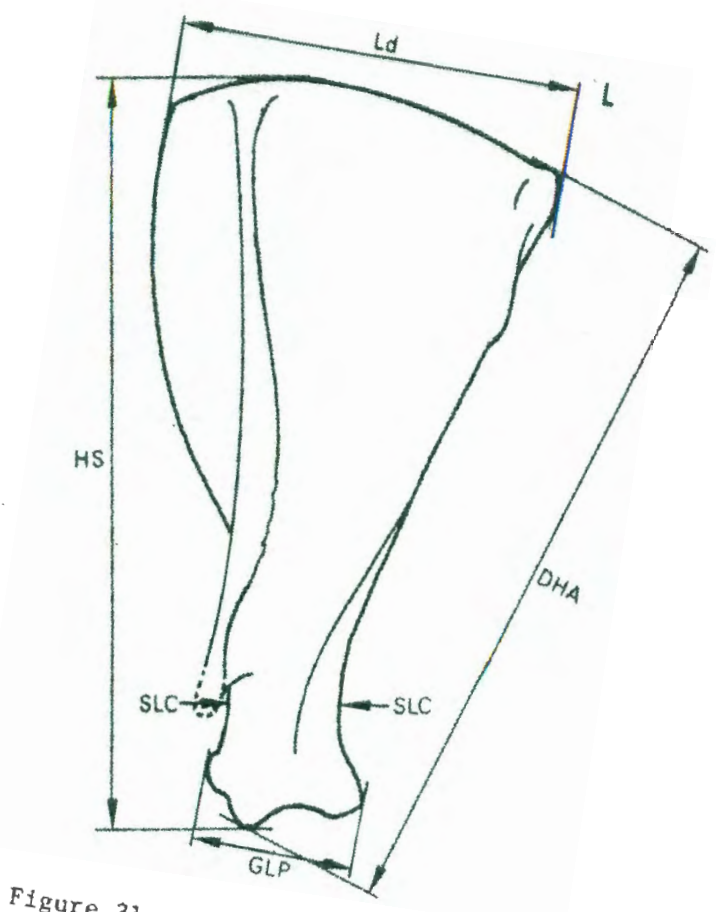

Ffigure $3 i_{a}$

Bos scapula, lateral view.

Scapula measurements

$\Xi$

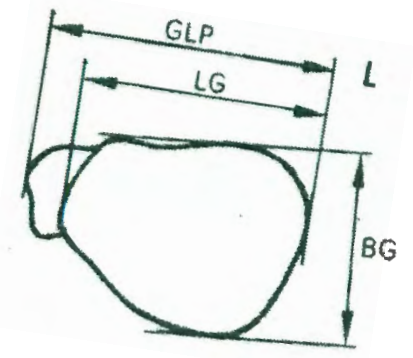

Figure 31b: Bos scapu distal view. 


\section{Appendix D}

Skull measurements. Measurements defined in von den Driesch (1976: 29-31) 
Appendix D Skull measurements. Measurements defined in von den Driesch (1976: 29-31). See Appendix E for illustrations of measurements.

Specimens

\begin{tabular}{|c|c|c|c|c|}
\hline measurement & ML-13194 & ML-13194 & ML-2014 & HL-1930 \\
\hline 1 & $46.3 \mathrm{~cm}$ & $48.7 \mathrm{~cm}$ & $52.5 \mathrm{~cm}$ & $\mathrm{~cm}$ \\
\hline 2 & 46.1 & 48.5 & & \\
\hline 3 & & & 47.5 & \\
\hline 4 & & & 35 & \\
\hline 5 & 12.1 & 13.1 & 130.9 & \\
\hline 6 & 24.6 & & & \\
\hline 7 & 28.2 & 29.5 & 30.5 & \\
\hline 8 & 18.8 & 20.1 & 22.1 & \\
\hline 9 & 23.1 & 24.2 & 26.5 & \\
\hline 12 & 18 & 18 & 19.3 & \\
\hline 13 & 23.2 & 23.1 & & \\
\hline 15 & 32 & 34 & & \\
\hline 16 & 13.9 & 14.2 & 15.5 & \\
\hline 17 & 25.4 & 26 & 28 & \\
\hline 18 & 22.6 & 20.1 & & \\
\hline 19 & 19.6 & 24.9 & 19 & \\
\hline 20 & & & 15.2 & \\
\hline 21 & 8.4 & 9.0 & 9.6 & \\
\hline 22 & & & 6.1 & \\
\hline 23 & 6.9 & 7.4 & 6.4 & \\
\hline 24 & 6.9 & 6.4 & 7.2 & \\
\hline 25 & 21.5 & 21.4 & 24 & \\
\hline 26 & 10.9 & 10.4 & 11.2 & \\
\hline 27 & 16.5 & 16.6 & 17.5 & \\
\hline 28 & 3.4 & 3.2 & 3.8 & 4.4 \\
\hline 29 & 4.0 & 4.1 & 4.5 & 4.7 \\
\hline 30 & 13.5 & 11.6 & 15.1 & 26.2 \\
\hline 31 & 19.5 & 22.2 & 30 & 25.5 \\
\hline 32 & 20.4 & 22.1 & 27.5 & \\
\hline 33 & 26 & 26.2 & 30.5 & 34 \\
\hline 34 & 16.2 & 19.4 & 20.3 & \\
\hline 35 & 16.3 & 17 & 18.6 & \\
\hline 36 & 81.4 & 9.9 & 9.0 & \\
\hline 37 & 8.9 & 8.1 & 8.9 & \\
\hline 38 & 15.2 & 14.4 & 14.3 & \\
\hline 39 & 2.8 & & 1.8 & \\
\hline 40 & & & 17.5 & \\
\hline 41 & & 13.8 & 14.5 & \\
\hline 42 & & & 56 & \\
\hline 43 & 43.8 & 46.2 & 6.0 & \\
\hline 45 & & 1.1 & & \\
\hline 46 & 4.7 & 4.5 & & \\
\hline 47 & & & 24 & \\
\hline 50 & & & 26 & \\
\hline 51 & 20.4 & 18 & 40.4 & \\
\hline 52 & 99.2 & 91.3 & 127.7 & \\
\hline
\end{tabular}


Appendix E

Illustrations of skull measurements (adapted from von den Driesch 1976) 
Appendix E Illustrations of skull measurements (adapted from von den Driesch 1976).

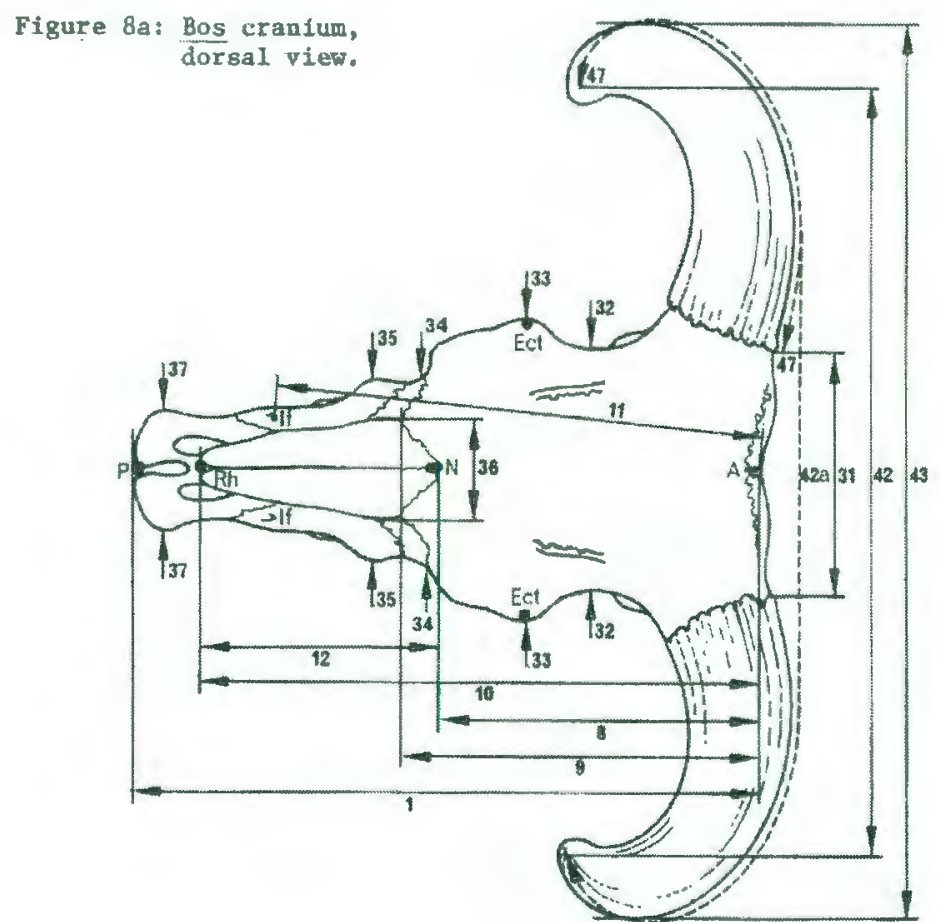

$\vec{\omega}$

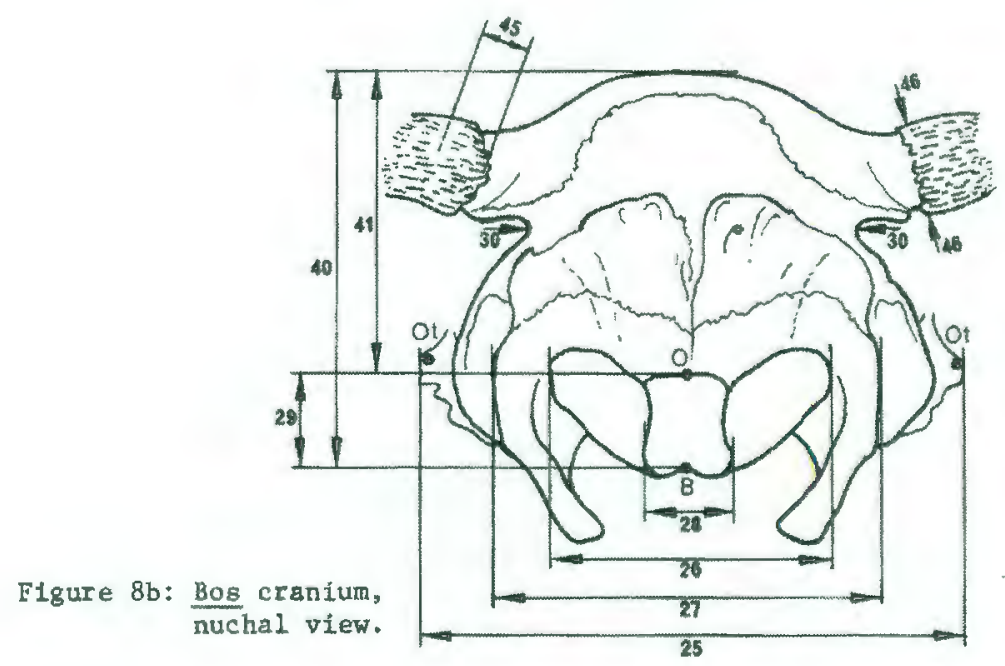

Skull measurements 

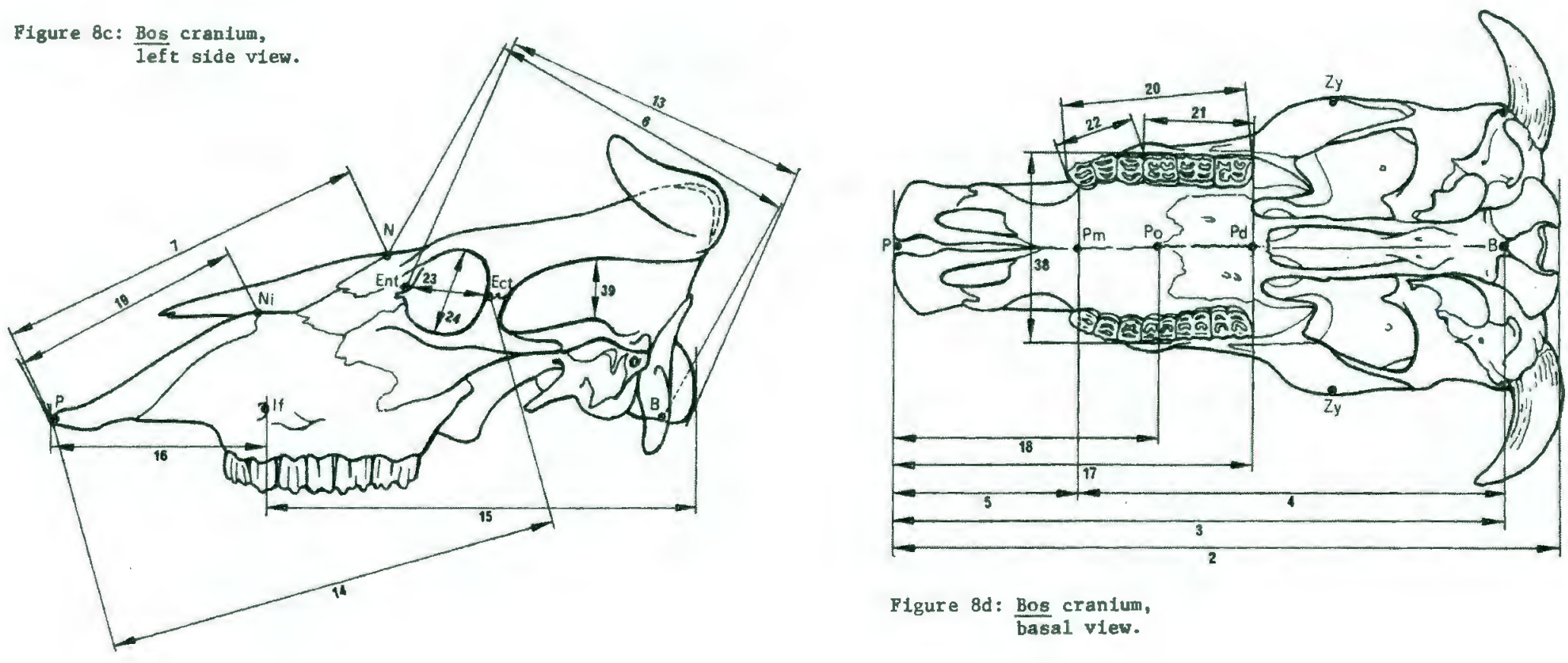

Figure 8d: Bos cranium,

Skull Measurements

$\vec{N}$ 